
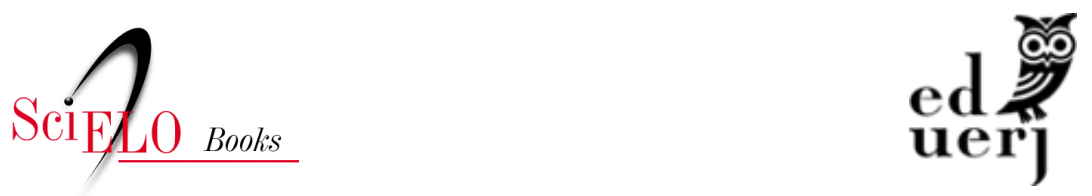

\title{
Capítulo II - Vizinhança escolarizada: a geografia das relações entre professor, famílias, habitantes e a cidade
}

\author{
Angélica Borges
}

\section{SciELO Books / SciELO Livros / SciELO Libros}

BORGES, A. Vizinhança escolarizada: a geografia das relações entre professor, famílias, habitantes e a cidade. In: A urdidura do magistério primário na Corte Imperial: um professor na trama de relações e agências [online]. Rio de Janeiro: EDUERJ, 2021, pp. 129-218. ISBN: 978-65-87949-20-8. https://doi.org/10.7476/9786587949208.0004.

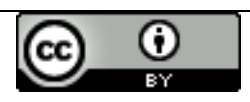

All the contents of this work, except where otherwise noted, is licensed under a Creative Commons Attribution 4.0 International license.

Todo o conteúdo deste trabalho, exceto quando houver ressalva, é publicado sob a licença Creative Commons Atribição 4.0.

Todo el contenido de esta obra, excepto donde se indique lo contrario, está bajo licencia de la licencia Creative Commons Reconocimento 4.0. 


\section{Capítulo II \\ Vizinhança escolarizada: a geografia das relaçóes entre professor, famílias, habitantes e a cidade}

...só ao professor, por estar mais contacto com o povo, é dado apreciar devidamente.

Professor Soares Brazil (1872)

Diante da polêmica do regime do tempo escolar em uma ou duas sessões de aula nas escolas públicas da Corte, o professor primário Carlos Augusto Soares Brasil fez um discurso em tom categórico: "a bem desse inconveniente apresentam-se outros ainda não menos dignos de atenção, que só ao Professor, por mais estar mais conctato com o povo, é dado apreciar devidamente" (AGCRJ, códice 10.4.19, 28 ago. 1872, f. 85-86). A proximidade dos professores com a população assinalava dois lados da mesma moeda. Por um lado, na perspectiva de Ilmar de Mattos (2004), ela colocava tais profissionais na condição de peças estratégicas na construção do Estado Imperial, como agentes da administração pública. Por outro, os professores sabiam que dispunham da possibilidade de exercer um poder, uma agência - propiciados pela autonomia da qual se faziam imbuir no exercício na profissão, mas também conferidos por sua condição e experiência de estarem em maior contato com o povo -, em favor de seus próprios interesses, fossem eles profissionais, econômicos, sociais ou políticos. Observa-se uma singular fronteira entre a subserviência e a autonomia, que tem a ver com o exercício da intelectualidade.

Uma análise da segunda condição torna possível observar múltiplas redes de relações constituídas em torno dos sujeitos escolares que transitavam no espaço do Município Neutro. Nesse sentido, torna-se importante compreender a dinâ- 
mica local em que as escolas e seus sujeitos estavam inscritos, as relações constituídas entre professores, alunos e habitantes, bem como seus efeitos no processo de escolarização e na configuração da profissão docente.

Durante a pesquisa, procurei mapear escolas, professores e adjuntos, e seus respectivos endereços. Porém, para dar prosseguimento à investigação até a escala dos sujeitos aos quais era destinada a ação escolar, foi necessário focalizar a pesquisa em torno de uma escola. No caso, a Escola Pública do sexo masculino da freguesia de Santa Rita, onde Pardal lecionava. A partir daí, a pesquisa se concentrou na identificação de alunos, pais ou encarregados, moradores, comerciantes e demais prestadores de serviços, a fim de analisar a distribuição dos referidos grupos no espaço atingido pela escolarização e, dessa maneira, apreender a geografia relacional que é constituída e sustentada por determinadas relações que se tornaram possíveis ou se fortaleceram por meio da existência da escola.

Para analisar quem eram esses sujeitos, que relações forjaram, como a escolarização afetou suas vidas e como essas relações afetavam a escolarização e o ofício docente, apresento uma reflexão que se divide, para organizar o enfoque de análise, mas que também se mescla, permitindo, portanto, que personagens transitem entre as divisões estabelecidas. Dessa forma, a reflexão se organiza em quatro momentos que visam pensar a freguesia de Santa Rita e sua escolarização; situar a escola pública regida por Pardal e seus sujeitos na localidade; discutir as atividades de pais, encarregados e parentes na dinâmica da cidade; e analisar os rumos e percursos tomados por seus ex-alunos.

\section{A "popular e comercial” freguesia de Santa Rita e sua escolarização}

A escola era na Rua do Costa, um sobradinho de grade de pau. O ano era de 1840. Naquele dia - uma segunda-feira, do mês de maio - deixei-me estar alguns instantes na Rua da Princesa a ver onde iria brincar amanhã. Hesitava entre o morro de S. Diogo e o Campo de Sant'Ana [...]. Morro ou campo? Tal era o problema. De repente disse comigo que o melhor era a escola. E guiei para a escola. Aqui vai a razão.

Conto de escola - Machado de Assis

O que a escola pública regida pelo professor Pardal, a infância de Machado de Assis e o Conto de Escola tinham em comum? Todos possuíam o mesmo cenário, a freguesia de Santa Rita, mais especificamente os arredores do Morro do Livramento. O Morro do Livramento fica situado entre os morros da Con- 
ceição e da Providência. Lá nasceu Machado de Assis, autor de Conto de Escola, história que se passa nos arredores do morro. No Largo ou na Rua da Imperatriz, onde começa a Ladeira do Livramento e também a Rua da Princesa, estava a escola pública onde lecionava o professor Pardal. A Rua do Costa, mencionada por Machado como endereço da escola do Conto, era paralela à rua da escola da freguesia de Santa Rita que, talvez, também tivesse a mesma vista do Morro do Livramento descrito por Machado, onde papagaios cortavam o céu azul, empinados pelos meninos. A curiosa coincidência não para por aí. Também há a proximidade temporal. Pardal tornou-se professor público em 1837, Machado nasceu em 1839 e o conto se passa em 1840. O escritor, o professor e a escola, cujas experiências se sucediam no mesmo lugar, nos conduzem a um ambiente da zona urbana carioca, marcado pelo comércio, pela movimentação do porto, pelos jogos dos capoeiras e pela circulação de pessoas de diferentes extratos sociais.

Figura 14 - Recorte da planta da parte central da cidade do Rio de Janeiro (1852). Freguesias assinaladas conforme descrições de Santos (1965)

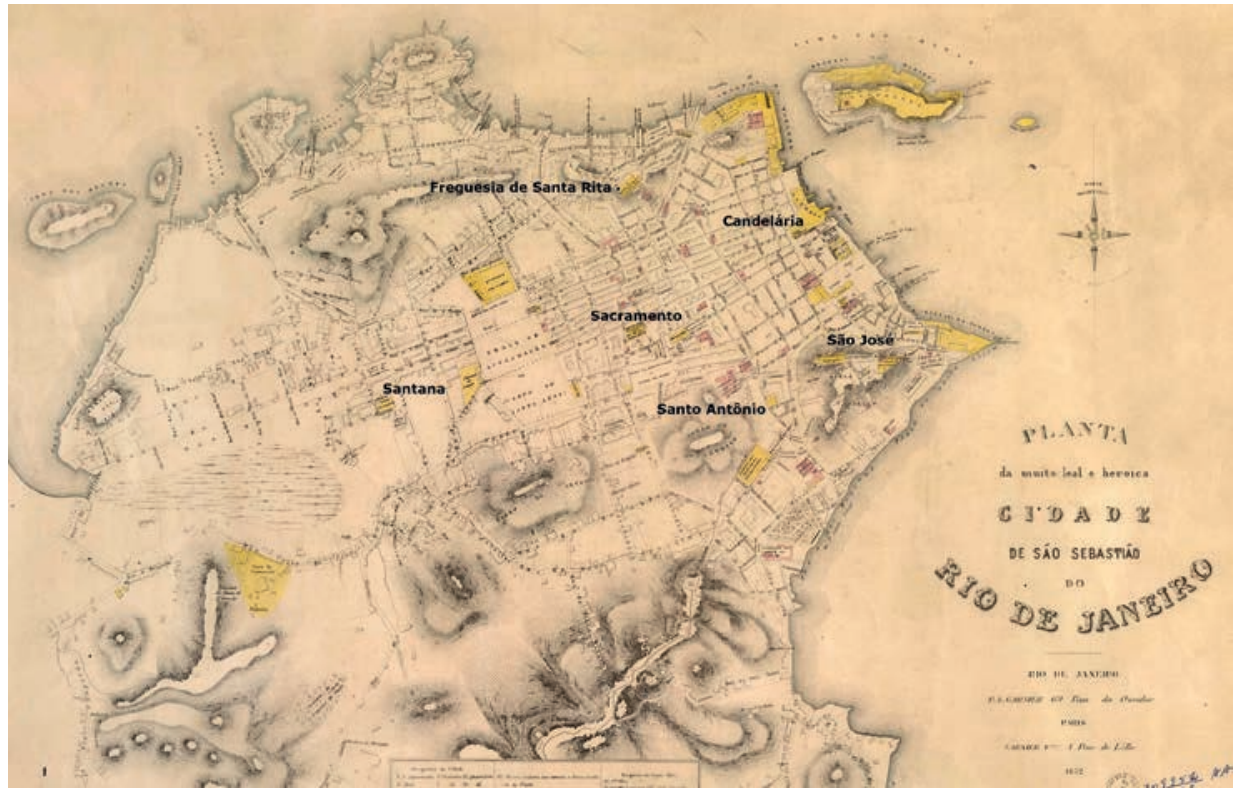

Fonte: Planta da muito leal e heroica cidade de São Sebastião do Rio de Janeiro, 1852, Biblioteca Nacional. 
Figura 15 - Região ampliada da freguesia de Santa Rita a partir da planta da figura 14

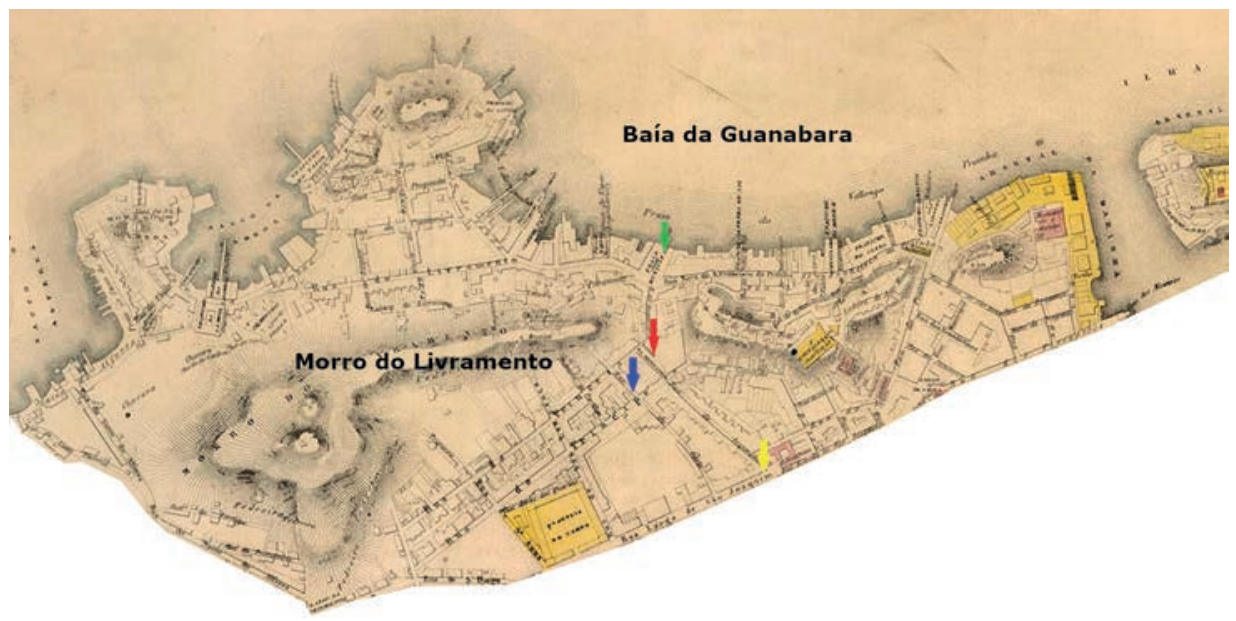

Fonte: Biblioteca Nacional.

Legenda:

$\rightarrow$ Escola pública de meninos (Largo da Imperatriz)

$\rightarrow$ Rua da Escola do Conto

$\rightarrow$ Imperial Colégio de Pedro II

$\rightarrow$ Cais da Imperatriz

Criada em 1721, a freguesia de Santa Rita tem esse nome em função de uma irmandade fundada por Manuel Nascentes Pinto e sua mulher Antonia Maria, que posteriormente teve sua igreja matriz inaugurada no Largo de Santa Rita. Compreende uma área que abrange o início da Rua Direita (atual Rua Primeiro de Março) e sua orla próxima à propriedade do Arsenal da Marinha, estendendo-se até a Gamboa, tendo como limites o Campo de Santana (pertencente à freguesia de igual nome). Esta área inclui os morros de São Bento, da Conceição, Livramento, Saúde, Gamboa e as ilhas de Cobras e de Santa Bárbara (Noronha Santos, 1965).

Juliana Souza (2007), em estudo acerca da ação da Câmara Municipal durante o Segundo Reinado e da regulação do comércio varejista de alimentos, investigou "as estratégias de negociação e a dinâmica dos conflitos instaurados entre a vereança, o governo central e a população” (p. 10). Ao enfocar algumas freguesias, a autora afirma que a de Santa Rita juntamente com a de Santana se tornaram na segunda metade do século XIX 
[...] áreas de grande concentração de trabalhadores pobres, aparecendo no censo de 1872, respectivamente, como as duas freguesias mais populosas da cidade. No processo de expansão geográfica e demográfica do centro urbano, sucessivas reformas afastaram gradativamente a população para essas freguesias, por conta do baixo preço de suas desvalorizadas moradias e pela conveniente distância do centro de atuação dos agentes do poder, do núcleo político-administrativo e comercial da cidade. Configuraram-se, desta forma, como um importante espaço de convívio entre trabalhadores pobres, muitos dos quais vivendo do comércio de alimentos (2007, p. 13).

Segundo a autora, o setor varejista abastecia todo mercado consumidor e "empregava um grande contingente de trabalhadores, como caixeiros, vendedores ambulantes, locatários de quiosques, ou proprietários de padarias, quitandas, tavernas, botequins, frege-moscas ${ }^{1}$ e casas de secos e molhados” (2007, p. 11). Mobilizava um conjunto de indivíduos que poderiam ter algum tipo de passagem pelas escolas locais, os alunos ou seus responsáveis, como, por exemplo, os proprietários de armazém de secos e molhados, de materiais para obra, sapateiro e relojoeiro que matricularam seus filhos na Escola Pública de Santa Rita.

Juliana Souza também chama atenção para os conflitos entre diversas instâncias de poder por motivos entre os quais se encontram a normatização das práticas dos trabalhadores do comércio, bem como outras atividades definidas por códigos de posturas, o que igualmente incluía as punições por infrações às normas estabelecidas. Nesse sentido, cabe destacar o nome de Manoel Machado Fagundes, pai de aluno da escola investigada, proprietário de armazém de secos e molhados na Rua da Imperatriz, n. ${ }^{\circ} 30$ - endereço informado no mapa de matrícula como também sendo de sua residência -, entre os multados da freguesia de Santa Rita pela "polícia fiscal” (Correio Mercantil, 06 jun. 1850) e de José Joaquim Ferreira Leal, proprietário de pedreira, na lista de multados por infração às posturas municipais da freguesia de Sacramento (Correio Mercantil, 14 dez. 1852). As notas não informam quais os motivos das multas, mas mostram a atuação dos poderes públicos na regulação da cidade que miravam os vários sujeitos que exerciam algum tipo de atividade passível de normatização, como os pais e encarregados de alunos da escola de Santa Rita. Podemos incluir nesse

1 Frege-moscas: Bras. Pop. Restaurante popular de má qualidade, ger. sujo; frege; tasca. Disponível em http://www.aulete.com.br/Frege-moscas. Acesso em 14 jan. 2020. 
conjunto de multas tomadas pelos sujeitos investigados aquelas por falta nas sessões do júri da Corte e por não acender os lampiões da localidade, entre outras.

A freguesia de Santa Rita era uma área formada pelo exercício de diversas atividades e onde estavam sediadas diferentes instituições. Nela funcionavam o Trapiche Mauá, a Praça do Mercado da Harmonia, a Cadeia do Aljube na Rua da Prainha, junto à ladeira do Morro da Conceição, a Escola e o Arsenal da Marinha, o Imperial Colégio de D. Pedro II, o Mosteiro dos frades beneditinos, o Liceu Literário Português, várias igrejas e escolas. Os nomes atribuídos aos logradouros da região onde esteve instalada a escola tem uma história relacionada à chegada de D. Teresa Cristina. Em 1843, ela desembarcou e caminhou, em cortejo real, pelos locais que receberam os nomes de Largo da Imperatriz e Rua da Imperatriz. O cais, também chamado da Imperatriz, construído especialmente para a chegada da nova monarca no lugar onde antes ficava o Cais do Valongo, foi recentemente localizado nas obras de recuperação da zona portuária da cidade do Rio de Janeiro, em 2011. Alvo das reformas de Pereira Passos no início do século XX, ele havia desaparecido da paisagem urbana carioca.

Nas proximidades da "região da Imperatriz" - cais, largo e rua -, estavam situados importantes lugares, como o conjunto de ruas e de acessos ao Morro do Livramento e ao Morro da Conceição, as ruas Larga e Estreita de São Joaquim, a Rua do Príncipe e a Rua da Princesa. O Almanak Laemmert registra a existência de um comércio intenso na área, formado por diversos armazéns, fábricas, lojas, escritórios e oficinas de prestadores de serviços como médicos, alfaiates, carpinteiros, mestres de obra, ferreiros, ourives, pintores, entre outros.

A freguesia tinha sido o local onde também desembarcavam escravizados, no antigo Cais do Valongo. Cemitérios de africanos e sítios arqueológicos relacionados à escravidão vêm sendo localizados ultimamente na região, compondo o Circuito Histórico e Arqueológico da Herança Africana criado pela Prefeitura do Rio de Janeiro. O próprio Morro do Livramento era parte da "Quinta do Livramento”, uma fazenda onde existiam vários escravizados. Segundo relato de Maria Graham, viajante que esteve no Rio entre 1821 e 1823: "Hoje eu vi o Val Longo [Valongo]. É o mercado de escravos do Rio. Quase todas as casas desta longuíssima rua são depósitos de escravos" (Graham apud Honorato, 2008, p. 77). 
Figura 16 - Lugar onde ficava o Cais da Imperatriz, antigo Cais do Valongo (Praça Municipal, fotografia de Augusto Malta, 1904, AGCRJ)

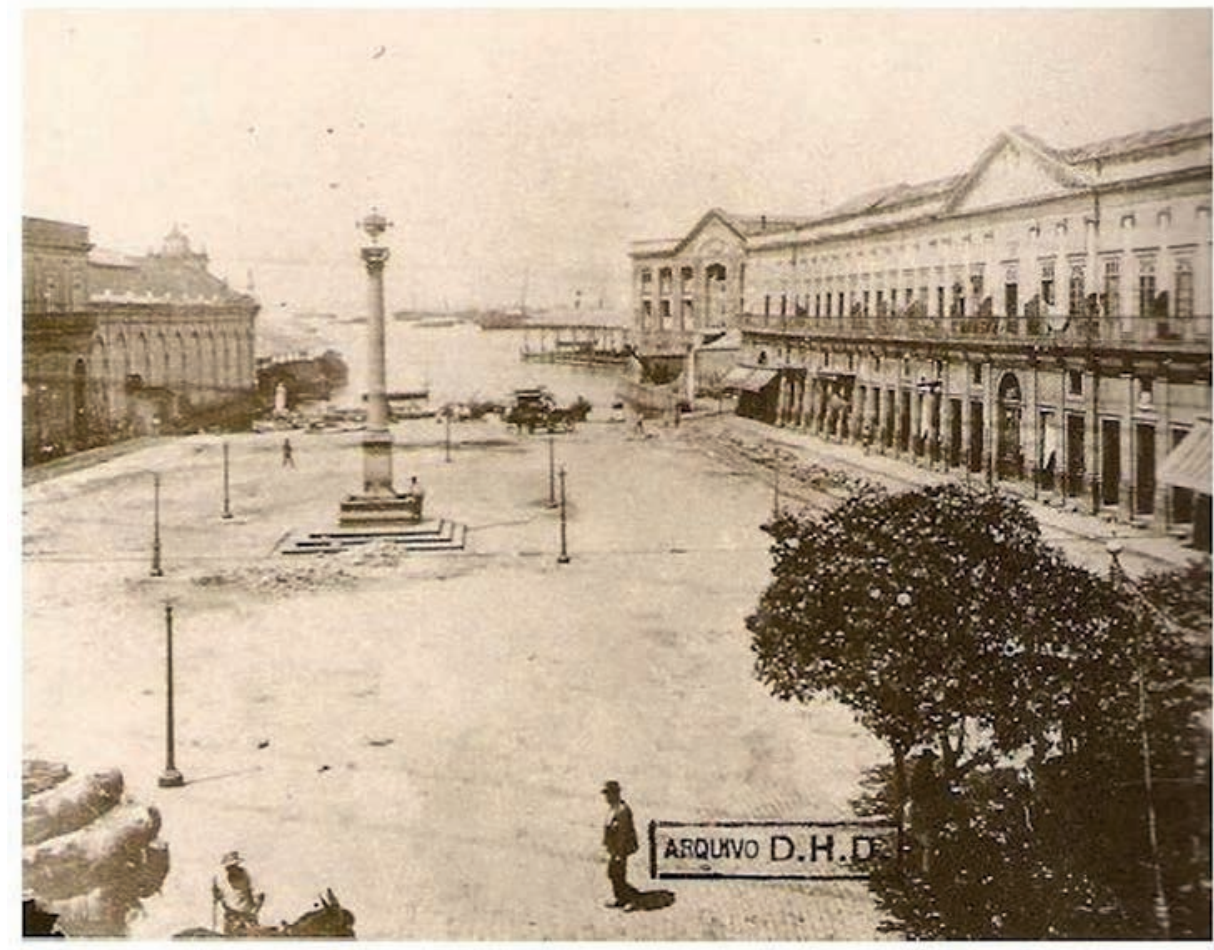

Fonte: Lima et al. (2016).

Conhecer a dinâmica da região também nos permite compreender o modo de funcionamento da escola que tem o cotidiano perpassado pelas culturas locais, hábitos e costumes da população. A própria rua onde ficava a Escola de Santa Rita possuía diversos estabelecimentos, principalmente os voltados para venda de alimentos, além de oficinas de serralheiros, marceneiros e sapateiros, entre os quais dois armazéns de secos e molhados de propriedade de pais de alunos da escola (João Baptista Coelho e Manuel Machado Fagundes). Nos logradouros próximos à $1{ }^{\text {a }}$ Escola Pública de Santa Rita também existiam várias outras escolas, entre públicas e particulares, como pode ser observado no quadro 11, montado com base nos dados do Almanak Laemmert: 
Quadro 11 - Estabelecimentos de ensino nas proximidades da Escola Pública de Santa Rita

\begin{tabular}{|c|c|c|c|c|c|}
\hline Ruas & 1850 & 1854 & 1860 & 1864 & 1874 \\
\hline $\begin{array}{l}\text { Largo da } \\
\text { Imperatriz }\end{array}$ & & & $\begin{array}{l}\mathrm{N}^{\circ} 121-1^{\mathrm{a}} \\
\text { Escola pública } \\
\text { de meninos } \\
\text { da freguesia } \\
\text { de Santa Rita } \\
\text { (Candido } \\
\text { Pardal) }\end{array}$ & $\begin{array}{l}\mathrm{N}^{\circ} 121-1^{\mathrm{a}} \\
\text { Escola pública } \\
\text { de meninos } \\
\text { da freguesia } \\
\text { de Santa Rita } \\
\text { (Candido } \\
\text { Pardal) }\end{array}$ & \\
\hline $\begin{array}{l}\text { Rua da } \\
\text { Imperatriz }\end{array}$ & $\begin{array}{l}\mathrm{N}^{\circ} 42-1^{\mathrm{a}} \\
\text { Escola pública } \\
\text { de meninos } \\
\text { da freguesia } \\
\text { de Santa Rita } \\
\text { (Candido } \\
\text { Pardal) } \\
\mathrm{N}^{\circ} 12-1^{\text {a }} \\
\text { Escola pública } \\
\text { de meninos da } \\
\text { freguesia de } \\
\text { Sacramento } \\
\text { (Joaquim } \\
\text { Sabino Pinto } \\
\text { Ribeiro) } \\
\mathrm{N}^{\circ} 133 \text { - Colé- } \\
\text { gio de Santa } \\
\text { Prisciliana }\end{array}$ & $\begin{array}{l}\mathrm{N}^{\circ} 121 \text { - } 1^{\mathrm{a}} \\
\text { Escola pública } \\
\text { de meninos } \\
\text { da freguesia } \\
\text { de Santa Rita } \\
\text { (Candido } \\
\text { Pardal) } \\
\mathrm{N}^{\circ} 133 \text { - Colé- } \\
\text { gio de Santa } \\
\text { Prisciliana de } \\
\text { D. Florinda de } \\
\text { Athayde Pes- } \\
\text { tana de Simas } \\
\mathrm{N}^{\circ} 126 \text { - Colé- } \\
\text { gio de meninas } \\
\text { de D. Cypriana } \\
\text { Augusta } \\
\text { Mendes } \\
N^{\circ} 173 \text { - } \\
\text { Colégio de } \\
\text { D. Felisberta } \\
\text { Augusta Soares } \\
\text { Gonzaga }\end{array}$ & $\begin{array}{l}\mathrm{N}^{\circ} 32-\text { Colé- } \\
\text { gio das Duas } \\
\text { Coroas de } \\
\text { D. Felisberta } \\
\text { Augusta Soares } \\
\text { Gonzaga }\end{array}$ & $\begin{array}{l}\text { N}^{\circ} 107 \text { - Colé- } \\
\text { gio de São João } \\
\text { Evangelista, de } \\
\text { Alexandre Bap- } \\
\text { tista Gomes } \\
\mathrm{N}^{\circ} 133 \text { - Colé- } \\
\text { gio de Santa } \\
\text { Prisciliana de } \\
\text { Maria Angélica } \\
\text { Pestana de } \\
\text { Simas Eneas }\end{array}$ & $\begin{array}{l}N^{\circ} 39 \text { - } \\
\text { Externato para } \\
\text { meninas de D. } \\
\text { Maria Castag- } \\
\text { nier Ferrez } \\
\text { No }^{\circ} 42 \text { - Colé- } \\
\text { gio de Santa } \\
\text { Margarida, } \\
\text { dirigido por } \\
\text { Margarida } \\
\text { Fortunata de } \\
\text { Almeida. } \\
\text { No } 82 \text { - Colé- } \\
\text { gio de São Luiz } \\
\text { de Pedro Adol- } \\
\text { pho L'Abbé } \\
\text { No } 101 \text { - Colé- } \\
\text { gio de Santa } \\
\text { Maria } \\
\text { No } 107 \text { - Colé- } \\
\text { gio de São João } \\
\text { Evangelista, } \\
\text { de G Kemp } \\
\text { Larbeck }\end{array}$ \\
\hline $\begin{array}{l}\text { Rua do } \\
\text { Príncipe (dos } \\
\text { Cajueiros) }\end{array}$ & $\begin{array}{l}\text { S/N - Colégio } \\
\text { de D. Rita de } \\
\text { Cássia Alcebía- } \\
\text { des (internas e } \\
\text { externas) } \\
\mathrm{N}^{\circ} 128 \text { - Colé- } \\
\text { gio Mercantil } \\
\text { de H. G. } \\
\text { Cussen } \\
\mathrm{N}^{\circ} 188 \text { - Colé- } \\
\text { gio Escolha } \\
\text { da Mocidade } \\
\text { de Francisco } \\
\text { J.Borges }\end{array}$ & $\begin{array}{l}\text { S/N - Colégio } \\
\text { de D. Rita de } \\
\text { Cássia Alcebía- } \\
\text { des (internas e } \\
\text { externas) } \\
N^{\circ} 118 \text { - Aula } \\
\text { de Santa Ana, } \\
\text { D. Umbelina } \\
\text { Maria da Con- } \\
\text { ceição Cruz } \\
\text { (meninas) }\end{array}$ & $\begin{array}{l}\text { No }^{\circ} 102 \text { - Colé- } \\
\text { gio de D. Rosa } \\
\text { Joaquina da } \\
\text { Silva Braga }\end{array}$ & $\begin{array}{l}\text { No } 114 \text { - Colé- } \\
\text { gio de Santa } \\
\text { Margarida, de } \\
\text { D. Margarida } \\
\text { Fortunata de } \\
\text { Almeida }\end{array}$ & \\
\hline
\end{tabular}




\begin{tabular}{|c|c|c|c|c|}
\hline $\begin{array}{l}\text { Rua da Princesa } \\
\text { (dos Cajueiros) }\end{array}$ & $\begin{array}{l}\text { S/N - Colégio } \\
\text { de Português e } \\
\text { Francês }\end{array}$ & $\begin{array}{l} \\
\mathrm{N}^{\circ} 79-2^{\mathrm{a}} \\
\text { Escola pública } \\
\text { de meninos } \\
\text { da freguesia } \\
\text { de Santana } \\
\text { (prof. João José } \\
\text { Moreira) }\end{array}$ & \begin{tabular}{|l|} 
\\
\\
$\mathrm{N}^{\circ} 79-2^{\mathrm{a}}$ \\
Escola pública \\
de meninos \\
da freguesia \\
de Santana \\
(prof. João José \\
Moreira)
\end{tabular} & $\begin{array}{l}\mathrm{N}^{\circ} 138-1^{\mathrm{a}} \\
\text { Escola pública } \\
\text { de meninos da } \\
\text { freguesia de } \\
\text { Santana (prof. } \\
\text { Augusto Can- } \\
\text { dido Xavier } \\
\text { Cony) } \\
\mathrm{N}^{\circ} 123 \mathrm{~A}-2^{\mathrm{a}} \\
\text { Escola pública } \\
\text { de meninas da } \\
\text { freguesia de } \\
\text { Santana (profa. } \\
\text { Zulmira Eliza- } \\
\text { beth da Costa } \\
\text { Cirne) }\end{array}$ \\
\hline $\begin{array}{l}\text { Rua Nova do } \\
\text { Príncipe }\end{array}$ & & & $\begin{array}{l}1^{\text {a }} \text { Escola } \\
\text { pública de } \\
\text { meninas da } \\
\text { freguesia de } \\
\text { Santa Rita } \\
\text { (Prof. Fran- } \\
\text { cisca de Paula } \\
\text { de Moraes e } \\
\text { Lima) }\end{array}$ & $\begin{array}{l}\text { No } 80-1^{\text {a }} \\
\text { Escola pública } \\
\text { de meninos } \\
\text { da freguesia } \\
\text { de Santa Rita } \\
\text { (Candido } \\
\text { Pardal) }\end{array}$ \\
\hline Rua da Saúde & & $\begin{array}{l} \\
\text { No } 101 \text { - Colé- } \\
\text { gio de Instrução } \\
\text { Primária, } \\
\text { dirigido por } \\
\text { João Victorino } \\
\text { de Miranda } \\
\mathrm{N}^{\circ} 170-2^{a} \\
\text { Escola pública } \\
\text { de meninos } \\
\text { da freguesia } \\
\text { de Santa Rita } \\
\text { (prof. José } \\
\text { Bernardes } \\
\text { Moreira) }\end{array}$ & \begin{tabular}{|l|}
$N^{\circ}$ 99 - Colé- \\
gio de Instrução \\
elementar \\
(sistema Valde- \\
taro), dirigido \\
por Manoel \\
Ferreira das \\
Neves \\
$N^{\circ} 170$ - 2a \\
Escola pública \\
de meninos \\
da freguesia \\
de Santa Rita \\
(prof. José \\
Bernardes \\
Moreira) \\
$N^{\circ} 211$ - Colé- \\
gio de Santa \\
Sophia, de D. \\
Firma Maria \\
Joaquina da \\
Silva Ramos
\end{tabular} & $\begin{array}{l}\text { No } 186 \text { - Colé- } \\
\text { gio de Nossa } \\
\text { Senhora da } \\
\text { Graça de Dona } \\
\text { Florisbela da } \\
\text { Fonseca } \\
\text { No } 91 \text { - Colé- } \\
\text { gio de D. Rosa- } \\
\text { lina Preciosa de } \\
\text { Sampaio }\end{array}$ \\
\hline
\end{tabular}




\begin{tabular}{|c|c|c|c|c|c|}
\hline $\begin{array}{l}\text { Rua do } \\
\text { Livramento }\end{array}$ & $\begin{array}{l}\text { No } 18 \text { - Colé- } \\
\text { gio de Meninas } \\
\text { NN}^{\circ} 122 \text { - Colé- } \\
\text { gio São Pedro } \\
\text { de Alcântara, } \\
\text { dirigido pelo } \\
\text { padre José } \\
\text { Mendes de } \\
\text { Paiva } \\
\text { No }^{\circ} 17 \text { - Colé- } \\
\text { gio de Santa } \\
\text { Cruz }\end{array}$ & $\begin{array}{l}\text { S/N - Colé- } \\
\text { gio de Santa } \\
\text { Teresa, dirigido } \\
\text { pela Sra. viúva } \\
\text { Peixoto } \\
\text { No } 122 \text { - Colé- } \\
\text { gio São Pedro } \\
\text { de Alcântara, } \\
\text { dirigido pelo } \\
\text { padre José } \\
\text { Mendes de } \\
\text { Paiva }\end{array}$ & $\begin{array}{l}\text { N } 64 \text { - Colé- } \\
\text { gio da Nossa } \\
\text { Senhora da } \\
\text { Conceição, } \\
\text { de Maria de } \\
\text { Jesus da Cruz } \\
\text { Santos, filha da } \\
\text { falecida pro- } \\
\text { fessora pública } \\
\text { Polucena Maria } \\
\text { da Conceição } \\
\text { Cruz } \\
\text { N }^{\circ} 39 \text { (na Tra- } \\
\text { vessa) - Colégio } \\
\text { da Congrega- } \\
\text { ção das irmãs } \\
\text { alemãs do Sacro } \\
\text { Coração de } \\
\text { Maria }\end{array}$ & $\begin{array}{l}\mathrm{N}^{\circ} 21-2^{\mathrm{a}} \\
\text { Escola pública } \\
\text { de meninas da } \\
\text { freguesia de } \\
\text { Santa Rita - } \\
\text { (prof. }{ }^{\mathrm{a}} \text { Delfina } \\
\text { Rosa da Silva } \\
\text { Vasconcellos) }\end{array}$ & $\begin{array}{l}N^{\circ} 122-2^{\mathrm{a}} \\
\text { Escola pública } \\
\text { de meninas da } \\
\text { freguesia de } \\
\text { Santa Rita - } \\
\text { (prof. Theresa } \\
\text { Leopoldina de } \\
\text { Araújo) }\end{array}$ \\
\hline $\begin{array}{l}\text { Morro do } \\
\text { Livramento }\end{array}$ & & & \begin{tabular}{|l} 
Entrada pela \\
rua de S. Lou- \\
renço, Imperial \\
Instituto dos \\
Surdos-mudos, \\
dirigido pelo \\
Rev. padre-mes- \\
tre Frei João de \\
Nossa Senhora \\
do Carmo
\end{tabular} & $\begin{array}{l}\text { Entrada pela } \\
\text { rua de S. Lou- } \\
\text { renço, Imperial } \\
\text { Instituto dos } \\
\text { Surdos-mudos, } \\
\text { dirigido pelo } \\
\text { Rev. padre-mes- } \\
\text { tre Frei João de } \\
\text { Nossa Senhora } \\
\text { do Carmo }\end{array}$ & \\
\hline $\begin{array}{l}\text { Rua de São } \\
\text { Francisco da } \\
\text { Prainha }\end{array}$ & $\begin{array}{l}\mathrm{N}^{\circ} 4 \text { - Colégio } \\
\text { de D. Cypriana } \\
\text { Jacintha } \\
\text { Mendes }\end{array}$ & & & & \\
\hline $\begin{array}{l}\text { Travessa das } \\
\text { Partilhas }\end{array}$ & & $\begin{array}{l}N^{\circ} 1 \text { - Colégio } \\
\text { de D. Ana Ran- } \\
\text { gel de Bulhões }\end{array}$ & & & \\
\hline $\begin{array}{l}\text { Rua da Con- } \\
\text { ceição }\end{array}$ & & $\begin{array}{l}\mathrm{N}^{\circ} 16-\text { Aula } \\
\text { de Comercio da } \\
\text { Corte }\end{array}$ & & & \\
\hline $\begin{array}{l}\text { Rua Larga de } \\
\text { São Joaquim }\end{array}$ & $\begin{array}{l}\mathrm{N}^{\circ} 203- \\
\text { Colégio de Por- } \\
\text { tuguês e inglês } \\
\text { de Mathilde } \\
\text { Constança } \\
\text { Keating }\end{array}$ & $\begin{array}{l}\text { Imperial Colé- } \\
\text { gio de Pedro II }\end{array}$ & $\begin{array}{l}\text { Imperial Colé- } \\
\text { gio de Pedro II } \\
\text { Instituto } \\
\text { Comercial da } \\
\text { Corte }\end{array}$ & $\begin{array}{l}\text { Imperial Colé- } \\
\text { gio de Pedro II } \\
\mathrm{N}^{\circ} 94 \text { - Colégio } \\
\text { de D. Anna de } \\
\text { Castro }\end{array}$ & $\begin{array}{l}\text { Imperial Colé- } \\
\text { gio de Pedro II }\end{array}$ \\
\hline $\begin{array}{l}\text { Rua Estreita de } \\
\text { S. Joaquim }\end{array}$ & & & & $\begin{array}{l}\mathrm{N}^{\circ} 66-\text { Insti- } \\
\text { tuto Comercial } \\
\text { da Corte }\end{array}$ & \\
\hline Total & 12 escolas & 11 escolas & 11 escolas & 14 escolas & 12 escolas \\
\hline
\end{tabular}

Fonte: Quadro produzido pela autora a partir das informações do Almanak Laemmert. 
Figura 17 - Perímetro de abrangência do Quadro XI. Recorte da Planta da muito leal e heroica cidade de São Sebastião do Rio de Janeiro

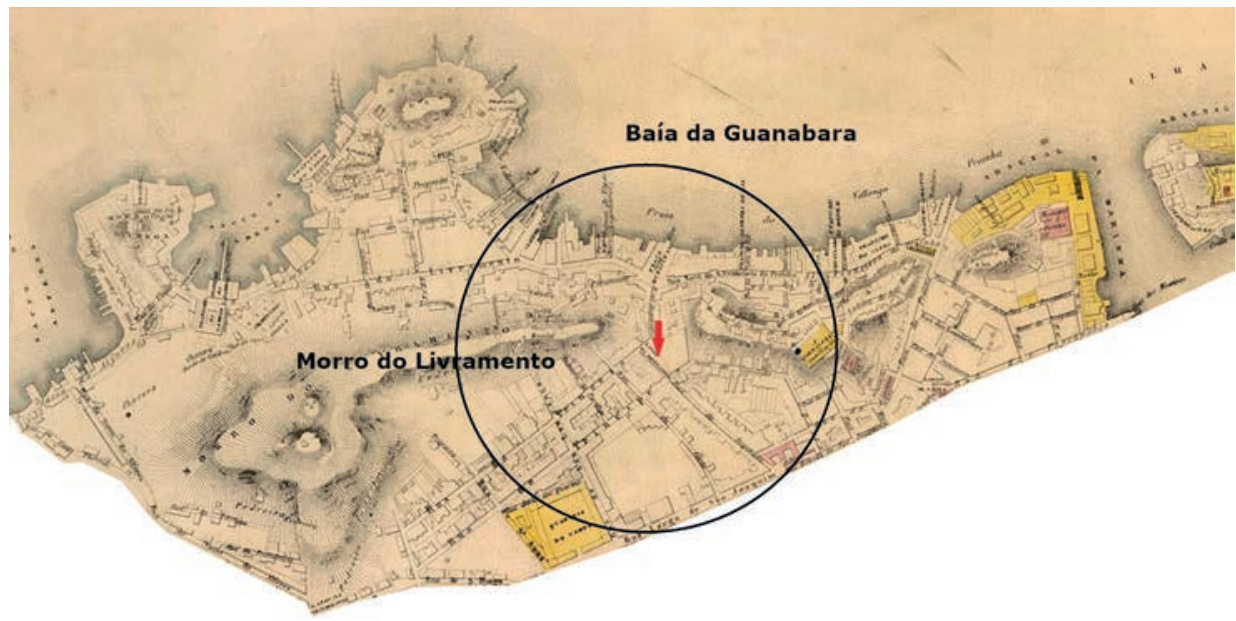

Fonte: Biblioteca Nacional.

A média de escolas existentes ao redor da Escola Pública da freguesia de Santa Rita, divulgadas pelo Almanak Laemmert, nesse período, era de doze estabelecimentos. O fato de algumas dessas escolas aparecerem em um determinado ano, mas não no outro, não significa que tenham encerrado suas atividades. Algumas mudaram de endereço, conforme registros do Almanak, saindo do perímetro da vizinhança da escola onde lecionava Pardal.

O quadro dá relevo à variedade de instituições, públicas e particulares, para meninos e meninas, de aulas avulsas, de ensino primário, secundário e profissionalizante. O Imperial Colégio de D. Pedro II ficava muito próximo da escola de meninos de Santa Rita, o que facilitava, para o professor Pardal, conciliar a docência entre as duas instituições, juntamente com a cadeira de desenho linear e caligrafia do Instituto Comercial da Corte, que durante um período funcionou no prédio do Externato do Colégio de D. Pedro II. Outro aspecto que se destaca é a alocação das escolas públicas, denominadas de outra freguesia, nas ruas de Santa Rita. Entre os possíveis motivos, estavam as dificuldades de se encontrar prédios mais adequados para instalação das escolas e também a especulação imobiliária na freguesia de origem, o que acontecia, principalmente, quando os proprietários tinham conhecimento de que o prédio seria usado para a instalação de uma escola pública. 
O aspecto que se ressalta nas fontes, porém, é o fato de haver uma significativa quantidade de escolas concentradas em uma mesma região no período. Haveria uma demanda da localidade por escolarização? O número de alunos da escola de Pardal também era consideravelmente grande, o que indica que, se não a frequentavam efetivamente, ao menos tinham um interesse pela escola.

\section{A Primeira Escola Pública de meninos da freguesia de Santa Rita}

A Escola Pública de meninos da freguesia de Santa Rita - que em 1858 passa a ser chamada de $1^{a}$ escola em razão da criação de uma $2^{\text {a }}$ cadeira na freguesia mudou de endereço várias vezes, sempre nas imediações do Largo da Imperatriz, até o ano de 1877, quando ganhou um prédio próprio, que hoje é ocupado pelo Centro Cultural José Bonifácio. Não foi possível precisar a data de sua criação, mas, segundo informações de Cardoso (1999), parece que funcionava antes mesmo de 1818, ano em que tomou posse o professor Venâncio José da Costa por causa da morte do professor João Esteves de Araújo. Venâncio pediu remoção para freguesia de Paquetá em 1837, o que possibilitou a entrada de Pardal em seu lugar. Diante disso, emerge a hipótese de que a escola tivesse funcionado como aula régia.

Em 1839, Pardal constava numa lista dos professores que usavam o método mútuo (AGCRJ, códice 10.4.4, f. 3). Alguns anos depois, no entanto, em relatório sucinto ao final da folha de um mapa de alunos de 1855, o delegado da instrução de Santa Rita, José Agostinho Moreira Guimarães, asseverava que o professor, "um dos mais habilitados do Município", seguia o método "misto, de mútuo e simultâneo”, com 153 alunos. Segundo o delegado, na escola a

[...] disciplina é rigorosamente observada, e de tal modo está estabelecida nos hábitos dos escolares que não se achando presente o Professor (como observei em uma das minhas visitas) os meninos guardam toda a regularidade nos movimentos escolares, a decência e aplicação necessárias debaixo das vistas de seus monitores (AGCRJ, Série instrução pública, Códice 14.3.8, 5 abr. 1855).

Entre os motivos de ausência estava a participação em bancas examinadoras, em sessão do júri e aula no Imperial Colégio de D. Pedro II. Nesse sentido, cabe destacar um documento de 1856 em que o professor pede autorização para deixar a escola a cargo de seu adjunto nas tardes de quinta-feira para dar aula de desenho no Colégio (AGCRJ, códice 10.4.37, f. 10). A solicitação foi atendida 
e assim nos indica que a escola primária de Santa Rita atendia ao regime de duas sessões diárias, como previsto pelo Regulamento de 1854, e funcionava efetivamente no horário da tarde.

Um quadro chamado "Chave do sistema de ensino" registrado no verso do mapa de matrícula de 10 de janeiro de 1855 apresenta como o professor distribuía os saberes de três áreas pelas dez classes em que organizava os alunos (AGCRJ, códice 14.3.15). Documentos posteriores sugerem que a divisão adotada pela inspetoria era de oito classes (Relatório da IGIPSC de 1872, anexo 4, p.12). No entanto, não foi possível saber se em 1855 estaria em vigor oficialmente uma divisão de dez classes, ou se tal organização tinha a ver com as concepções do professor.

Quadro 12 - Chave do sistema de ensino da escola de Santa Rita

\begin{tabular}{|c|l|c|l|c|l|}
\hline \multicolumn{2}{|l|}{ Classes de leitura } & \multicolumn{2}{l|}{ Classes de escrita } & \multicolumn{2}{l|}{ Classes de contabilidade } \\
\hline $1^{\text {a }}$ & Alfabeto & $1^{\text {a }}$ & Linhas retas oblíquas & $1^{\text {a }}$ & Números dígitos \\
\hline $2^{\mathrm{a}}$ & Monossílabas & $2^{\mathrm{a}}$ & Das curvas & $2^{\mathrm{a}}$ & $\begin{array}{l}\text { Dos comp. tos (?) a } \\
\text { (dezenas) }\end{array}$ \\
\hline $3^{\mathrm{a}}$ & Dissílabas & $3^{\mathrm{a}}$ & $\begin{array}{l}\text { Letras de corpos } \\
\text { primitivos }\end{array}$ & $3^{\mathrm{a}}$ & $\begin{array}{l}\text { Dos dos (?) (centenas } \\
\text { em diante) }\end{array}$ \\
\hline $4^{\mathrm{a}}$ & Polissílabas & $4^{\mathrm{a}}$ & $\begin{array}{l}\text { Das de dos (?) e asteas } \\
\text { superiores }\end{array}$ & $4^{\mathrm{a}}$ & Adição pequena \\
\hline $5^{\mathrm{a}}$ & Soletrado & $5^{\mathrm{a}}$ & $\begin{array}{l}\text { Das de dos (?) e das } \\
\text { inferiores }\end{array}$ & $5^{\mathrm{a}}$ & Da grande \\
\hline $6^{\mathrm{a}}$ & Expositor português & $6^{\mathrm{a}}$ & a b c & $6^{\mathrm{a}}$ & Subtração pequena \\
\hline $7^{\mathrm{a}}$ & Simão de Mântua & $7^{\mathrm{a}}$ & A B C & $7^{\mathrm{a}}$ & Da grande \\
\hline $8^{\mathrm{a}}$ & Historia do Brasil & $8^{\mathrm{a}}$ & Bastardo & $8^{\mathrm{a}}$ & Multiplicação \\
\hline $9^{\mathrm{a}}$ & Gramática & $9^{\mathrm{a}}$ & Bastardinho & $9^{\mathrm{a}}$ & Divisão \\
\hline $10^{\mathrm{a}}$ & Regência & $10^{\mathrm{a}}$ & Cursivo & $10^{\mathrm{a}}$ & Frações em diante \\
\hline
\end{tabular}

Fonte: Quadro feita pela autora com base em manuscrito do AGCRJ, códice 14.3.15.

O sistema permitia que o aluno fosse classificado em diferentes classes em qualquer época do ano, conforme demonstra os mapas de matrícula. A divisão também fazia parte do esquema do ensino mútuo e tinha a ver com os ritmos de aprendizagem: "O termo classe é totalmente exclusivo da noção da arquitetura ou de espaço. Só é entendido em relação à aquisição e ao conhecimento; a primeira classe é a dos iniciantes, e a oitava é a dos que concluem o curso escolar" (Lesage, 1999, p. 13). Cabe 
destacar que Cardoso (2002) levantou documentos a respeito de materiais didáticos do ensino mútuo e localizou uma Decisão de 16 de agosto de 1833 que mandou distribuir nas escolas tabelas de conteúdo para as classes de leitura e de aritmética. As tabelas dividiam os saberes por 16 classes e alguns dos conteúdos são similares aos listados por Pardal, bem como alguns compêndios, como o Expositor Português e Simão de Mântua. Apesar das diferenças, a semelhança existente entre as duas tabelas poderia sugerir uma reelaboração da prática docente, produzida com o passar dos anos e com as mudanças legais, que levasse em consideração experiências de ensino anteriores, como a do sistema mútuo.

Tal procedimento, que não era exclusivo da escola onde lecionava Pardal, favorecia um trânsito fluido de alunos, atrelado à permissão de entrada e saída em qualquer época do ano, não sendo preciso esperar o começo de um novo período letivo para serem matriculados, questão que era uma queixa recorrente dos professores. Quando Pardal se tornou diretor das escolas municipais, implementou um programa de ensino mais elaborado e minucioso, baseado no sistema Rapet, como veremos no capítulo IV, que supostamente atenuaria o problema.

O documento também assinala que: "Além das classes acima mencionadas há ainda as de declamação, doutrina cristã e desenho linear todas formadas pelos alunos da $8^{\mathrm{a}}, 9^{\mathrm{a}}$ e $10^{\mathrm{a}}$ classes de leitura e diretamente dirigidas pelo professor". $\mathrm{O}$ desenho linear e a declamação não estavam no conjunto de disciplinas obrigatórias do Regulamento de 1854, nem do Regimento de 1855, e podem assinalar uma agência formativa e a importância que o professor dava a esses saberes na escola elementar. Tais saberes eram ministrados nas classes em que os alunos já deveriam ler correntemente, estudar gramática e regência, multiplicação, divisão e frações. No caso da escrita, era o período da transição do uso da letra bastarda para letra cursiva, que era destinada à última classe, como se fosse o fechamento da aprendizagem da escrita. 
Figura 18 - Recorte de foto do mapa de matrícula de 02 de abril de 1855 (AGCRJ)

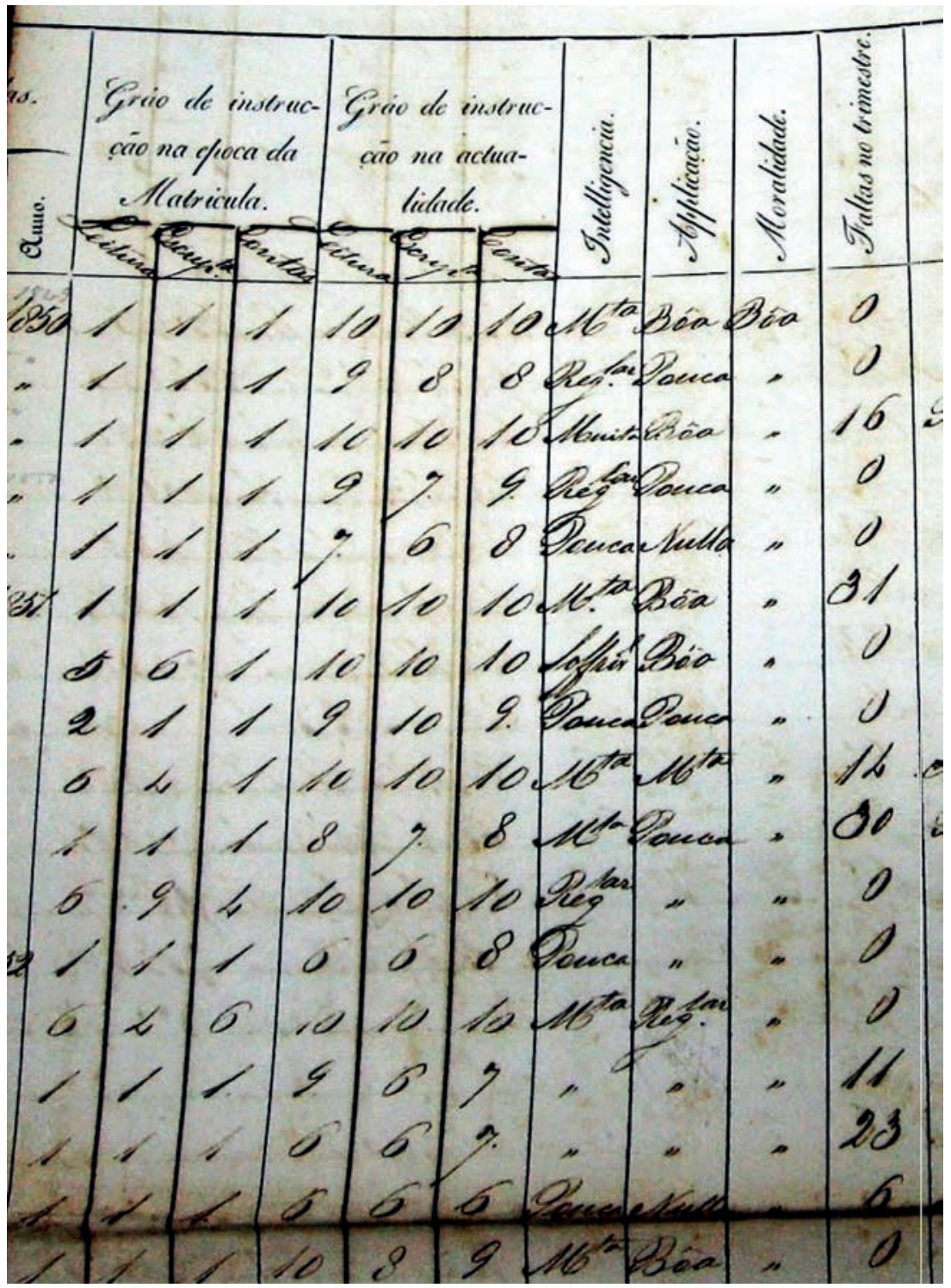

Fonte: Foto da autora.

Tal aspecto poderia sugerir que os vários alunos que saíam da escola antes da $10^{a}$ classe não teriam aprendido as letras bastarda e cursiva. Não obstante, vale considerar as estratégias dos sujeitos para aprendizagem de saberes e técnicas ainda mais em um espaço compartilhado por alunos que estavam em diferentes 
fases. Entre eles, vários alunos que estavam na última classe, como podemos observar na figura 18 (esta parte do mapa corresponde aos alunos mais antigos da escola). No entanto, documentos registram que o professor reclamava do fato de muitos pais retirarem os filhos da escola antes de chegarem à última classe.

A mobília e os objetos de uso das escolas eram definidos pelo Regimento Interno de 1855. De acordo com o artigo 7, as escolas deveriam ter: a imagem do "Senhor Crucificado", o retrato do Imperador, um relógio, um armário, mesa com estrado e uma cadeira de braços para o professor, cadeiras para visitantes, bancos e mesas inclinadas com tinteiros fixos, uma ampulheta, mapa do Brasil e da Província do Rio de Janeiro, "um quadro de madeira pintado de preto", esponja e giz para os exercícios de aritmética e ortografia, um quadro ou mapa com o sistema legal de pesos e medidas e dos valores das moedas do Império, quadros para leitura e com modelos de escrita, ardósias, papel, compêndios para os meninos pobres, ponteiros, cabides para chapéus, réguas com guarnição de metal, talha para água e vasilhas.

Entre os livros usados na escola naquele período estavam o Expositor Português, Simão de Mântua e História do Brasil, todos incluídos no âmbito do ensino da leitura. Em outros documentos podemos ver outros livros que passaram a ser usados. O ofício do professor pedindo livros em 10 de dezembro de 1861 (AGCRJ, códice 11.2.3, f. 48) serve como exemplo: 50 volumes de gramática, 30 da História Universal, 30 do Epítome da História do Brasil, 40 dos episódios da História Pátria, 50 da coleção de Fábulas, 50 do Catecismo da Doutrina Cristã e 40 de aritmética. São sete tipos de compêndios usados. Mesmo que nem todos os alunos os usassem, por estarem em diferentes etapas de aprendizagem, consiste em uma quantidade considerável para o ensino de primeiras letras, com destaque para o ensino de história. A quantidade requisitada pelo professor também sugere que não eram poucos os alunos que deles faziam uso.

Os livros eram escolhidos pela Inspetoria Geral; portanto, as outras escolas, a princípio, também poderiam dispor das mesmas obras. Uma reivindicação dos professores era que a Inspetoria, em vez de designar quais livros seriam adotados, aprovasse uma lista geral de livros autorizados para cada saber, deixando a cargo de cada professor escolher quais desses livros seriam usados na sua escola. A medida foi adotada em 1877, por decisão do Ministro do Império, quando foi aprovada a gramática do professor Augusto Cony "sem exclusão de quaisquer livros adotados anteriormente, ficando lícito a cada professor escolher entre as obras aprovadas, a que julgar mais conveniente ao ensino dos alunos" ( $O$ Globo, 03 abr. 1877). 
Para acompanharmos o posicionamento geográfico da $1^{a}$ Escola Pública em relação às demais (públicas) da mesma freguesia, apresento o quadro 13, com os endereços das escolas que puderam ser rastreadas por meio do Almanak Laemmert e os professores que nelas atuaram por ordem cronológica, com a data de suas nomeações. Cabe alertar que as datas apresentadas possuem uma discrepância de mais ou menos um ano em relação à data real, em decorrência da peculiaridade desse tipo de publicação. Não foram usados os dados dos relatórios da Inspetoria em todos os casos pelo fato de que só passaram a ser feitos a partir de 1855 e por não informarem o endereço das escolas com regularidade. As datas que foram retiradas do Almanak estão sinalizadas pela sigla AL.

Quadro 13 - Endereço das escolas públicas primárias da freguesia de Santa Rita

\begin{tabular}{|c|c|c|c|}
\hline $\begin{array}{l}\text { Escola do sexo mas- } \\
\text { culino }\end{array}$ & $\begin{array}{l}\text { Professores com data } \\
\text { de nomeação }\end{array}$ & $\begin{array}{l}\text { Escola do sexo } \\
\text { feminino }\end{array}$ & $\begin{array}{l}\text { Professoras com data } \\
\text { de nomeação }\end{array}$ \\
\hline $\begin{array}{l}1^{\text {a }} \text { cadeira } \\
\text { Rua da Imperatriz, } 42 \\
\text { (AL, 1844) } \\
\text { Rua da Imperatriz, } \\
121 \text { (AL, 1852) } \\
\text { Largo da Imperatriz, } \\
121 \text { (AL, 1856) } \\
\text { Largo da Imperatriz, } \\
125 \text { (AL, 1866) } \\
\text { Rua Nova do Prín- } \\
\text { cipe, esquina com a } \\
\text { da Imperatriz (AL, } \\
\text { 1868) } \\
\text { Rua Nova do Prín- } \\
\text { cipe, 125 (AL, 1871) } \\
\text { Rua Nova do Prín- } \\
\text { cipe, 80 (AL, 1873) } \\
\text { Rua Nova do Prín- } \\
\text { cipe, 80 e Rua da } \\
\text { Imperatriz, 125 (AL, } \\
\text { 1874) } \\
\text { Rua do Príncipe, } 80 \\
\text { (AL, 1875) } \\
\text { Rua da Imperatriz, } 70 \\
\text { (AL 1876) } \\
\text { Edifício da Rua da } \\
\text { Harmonia, (AL, } \\
1878 \text { ) } \\
\text { Edifício da Rua da } \\
\text { Harmonia, 62 (AL, } \\
1879 \text { ) - Onde hoje } \\
\text { funciona o Centro } \\
\text { Cultural José Boni- } \\
\text { fácio. }\end{array}$ & $\begin{array}{l}1^{\text {a }} \text { cadeira } \\
1837 \text { - Candido } \\
\text { Matheus de Faria } \\
\text { Pardal } \\
1874 \text { - Januário dos } \\
\text { Santos Sabino }\end{array}$ & $\begin{array}{l}\text { 1a cadeira } \\
\text { Rua dos Pescadores, } 59 \\
\text { (AL, 1844) } \\
\text { Rua das Violas, } 121 \text { (AL, } \\
1847 \text { ) } \\
\text { Rua das Violas } 141 \text { (AL, } \\
1850 \text { ) } \\
\text { Rua d’Alfandega, } 133 \\
\text { (AL, 1853) } \\
\text { Rua do Fogo, } 32 \text { (AL, } \\
\text { 1856) } \\
\text { Rua das Violas, 95(AL, } \\
1858 \text { ) } \\
\text { Rua da Conceição, } 7 \\
\text { (AL, 1861) } \\
\text { Rua da Imperatriz, } 88 \\
\text { (AL, 1862) } \\
\text { Rua Nova do Príncipe, } \\
\text { 80 (AL, 1863) } \\
\text { Rua da Imperatriz, } 103 \\
\text { (AL, 1868) } \\
\text { Praça Municipal, 1 (AL, } \\
\text { 1874) } \\
\text { Rua da Imperatriz, 65 } \\
\text { (AL, 1880) }\end{array}$ & $\begin{array}{l}1^{\text {a }} \text { cadeira } \\
1837 \text { - Francisca de } \\
\text { Paula de Moraes e Lima } \\
\\
\text { 1871 - Maria José dos } \\
\text { Santos Lara }\end{array}$ \\
\hline
\end{tabular}




\begin{tabular}{|c|c|c|c|}
\hline $\begin{array}{l}\text { 2a cadeira } \\
\text { Rua da Saúde, } 170 \\
\text { (1858) } \\
\text { Largo de Santa Rita, } 12 \\
\text { (AL, 1874) } \\
\text { Rua dos Andradas, } 87 \\
\text { (AL, 1879) } \\
\text { Rua da Prainha, } 138 \\
\text { (AL, 1882) } \\
\text { Rua S. Joaquim, } 132 \\
\text { (AL, 1889) vaga }\end{array}$ & $\begin{array}{l}\text { 2a cadeira } \\
1858 \text { - José Bernardes } \\
\text { Moreira } \\
1889 \text { - Vaga (AL) }\end{array}$ & $\begin{array}{l}\text { 2a cadeira } \\
\text { Rua do Propósito, } 19 \\
\text { (1858) } \\
\text { Rua do Livramento, } \\
21 \text { (AL, 1861) } \\
\text { Rua do Livramento, } \\
64 \text { (AL, 1868) } \\
\\
\text { Preenchida (s/e), (AL, } \\
1872) \\
\text { Rua do Livramento, } \\
122(\text { AL, 1873) } \\
\text { Rua do Livramento, } \\
130(\text { AL, 1875) } \\
\text { Edifício da Rua da } \\
\text { Harmonia, 62(AL, } \\
1878)- \text { Mesmo } \\
\text { prédio da } 1^{a} \text { escola de } \\
\text { meninos. }\end{array}$ & $\begin{array}{l}\text { 2a cadeira } \\
1858 \text { - Delphina Rosa } \\
\text { da Silva Vasconcellos } \\
1866 \text { - Alcida Brande- } \\
\text { lina da Costa Seixas } \\
1871 \text { - Vaga (AL) } \\
1871 \text { - Thereza Leopol- } \\
\text { dina de Araujo } \\
\text { (Depois passa a se cha- } \\
\text { mar Thereza Leopoldina } \\
\text { de Araujo Jacobina) } \\
\text { 1881 - Amélia Emilia da } \\
\text { Silva Santos }\end{array}$ \\
\hline $\begin{array}{l}3^{\text {a }} \text { cadeira - 1871 AL } \\
-- \\
\text { Rua Senador Pompeu, } \\
23 \text { (AL, 1882) } \\
\text { Rua Imperatriz, 1 (AL, } \\
1889)\end{array}$ & $\begin{array}{l}3^{\text {a cadeira }} \\
1871 \text { - Vaga (AL) } \\
1877 \text { - Não mencionada } \\
\text { (AL) } \\
1878 \text { - Agostinho José } \\
\text { Soares Brazil (AL) }\end{array}$ & $\begin{array}{l}3^{\text {a cadeira - }} \\
\text { Praça Municipal 1D } \\
(1872) \\
\text { Largo de Santa Rita, } 14 \\
\text { (AL, 1874) } \\
\text { Rua da Saúde, } 109 \text { (AL, } \\
\text { 1878) } \\
\text { Rua dos Ourives, } 185 \\
\text { (AL, 1789) }\end{array}$ & $\begin{array}{l}3^{\text {a }} \text { cadeira } \\
1871 \text { - Josepha Tho- } \\
\text { mazia da Costa Passos } \\
1872 \text { - Luiza Joaquina } \\
\text { de Queiroz Paiva } \\
\text { Mendes }\end{array}$ \\
\hline
\end{tabular}

Fonte: Quadro elaborado pela autora com base nos relatórios da IGIPSC, documentos manuscritos do AGCRJ e no Almanak Laemmert.

Os diversos endereços que cada escola ocupou mostram que a mudança frequente devida à falta de prédios escolares fazia com que professores, alunos e pais/encarregados ficassem sujeitos às especulações imobiliárias da época. Escolas e seus atores se viam obrigados a mudar de prédio por motivos variados como inadequação ao espaço (quando não era possível nenhuma forma de ajuste), insalubridade, barulho, má localização, aumento do aluguel, muito dos quais vinham conjugados.

Mas ao mesmo tempo em que a escola mudava de endereço várias vezes, o uso do prédio ocupado pela escola também poderia ter concomitantemente várias finalidades. Uma busca no Almanak Laemmert pelo endereço Largo ou Rua da Imperatriz, n. ${ }^{\circ} 121$, no período em que a escola estava instalada nele, mostra que o local era utilizado como moradia, comércio, oficina e escola. $\mathrm{O}$ uso do prédio como escola pode ser visto antes mesmo da instalação da escola 
pública no endereço. Cabe observar que a pesquisa no Almanak indica que os endereços Rua da Imperatriz, n. ${ }^{\circ} 121$, e Largo da Imperatriz, n. ${ }^{\circ} 121$, tratam-se do mesmo lugar. Com exceção da escola, que informava o endereço de forma padronizada, Gregório Corelli que também fazia uso do espaço, ora informava o Largo, ora a Rua, mantendo sempre o mesmo número 121, bem como o endereço do professor Pardal, quando mencionado em outras ocupações.

Quadro 14 - Endereço Largo/Rua da Imperatriz, n. 121 no Almanak Laemmert (1852 a 1860)

\begin{tabular}{|c|c|}
\hline ANO & Usos do endereço Largo/Rua da Imperatriz, 121 \\
\hline 1852 & -- \\
\hline 1853 & Gregório Corelli - preparador de objetos de História Natural \\
\hline 1854 & $\begin{array}{l}\text { Gregório Corelli - preparador de objetos de História Natural, "com uma riquíssima coleção dos } \\
\text { três reinos da natureza”. } \\
\text { Gregório Corelli - pintor de paisagem e retratista }\end{array}$ \\
\hline 1855 & -- \\
\hline 1856 & -- \\
\hline 1857 & -- \\
\hline 1858 & $\begin{array}{l}\text { Residência de David Petra de Barros - capitão-tenente do Corpo da Armada Nacional e } \\
\text { Imperial }\end{array}$ \\
\hline 1859 & $\begin{array}{l}\text { Francisco José Loureiro aparece na lista de farmácias e boticas com este endereço, sendo que sua } \\
\text { residência era na Rua do Costa. }\end{array}$ \\
\hline 1860 & Residência de David Petra de Barros - capitão de fragata \\
\hline 1861 & $\begin{array}{l}\text { Escritório do médico Antônio José Moreira Guimarães } \\
\text { Escritório do médico Emílio Gonzaga } \\
\text { Farmácia de Antonio Maurício de Carvalho }\end{array}$ \\
\hline 1862 & $\begin{array}{l}\text { Farmácia de Antonio Maurício de Carvalho } \\
\text { Oficina do carpinteiro de José Fernandes do Couto }\end{array}$ \\
\hline 1863 & $\begin{array}{l}2^{\circ} \text { andar - endereço do secretário da Companhia de Estrada de Ferro de D. Pedro II José } \\
\text { Ignácio de Mesquita } \\
\text { Armazém de mantimentos secos de Joaquim José Monteiro de Faria } \\
\text { Oficina do carpinteiro de José Fernandes do Couto } \\
\text { No }^{\circ} 121 \text { A - João José Gonçalves (Oficina de funileiros, latoeiros, fundidores e picheleiros) }\end{array}$ \\
\hline 1864 & $\begin{array}{l}\text { Armazém de mantimentos secos de Joaquim José Monteiro de Faria } \\
\text { Oficina do carpinteiro de José Fernandes do Couto } \\
\text { Oficina do carpinteiro de Joaquim Alves da Silva }\end{array}$ \\
\hline 1865 & $\begin{array}{l}\text { Armazém de mantimentos secos de Joaquim José Monteiro de Faria } \\
\text { Oficina do carpinteiro de Joaquim Alves da Silva }\end{array}$ \\
\hline
\end{tabular}

Fonte: Quadro elaborado pela autora com base no Almanak Laemmert. 
Contrastando os quadros, observa-se que a posição geográfica da escola, os usos do prédio e os indivíduos que o ocuparam colocam em evidência o espaço que pode ser apreendido a partir de diferentes perspectivas, como a dos sujeitos da cidade, a dos profissionais da escola e a do público atendido. No âmbito dos indivíduos que não eram professores, alunos ou seus encarregados, mas que tinham relação com o endereço, se destaca o artista italiano Gregório Corelli, que parecia estar com condições difíceis de vida, a considerar pela realização de um espetáculo beneficente, organizado por João Caetano, em prol do artista. Teria o professor Pardal cedido uma parte do prédio para abrigar as atividades de Corelli? Pardal havia se formado pela Academia de Belas Artes e, por isso, existia a probabilidade do professor ter contato com pessoas do meio. Corelli também mudou de endereços várias vezes, conforme registros do Almanak e a nota de jornal acerca do espetáculo beneficente informa que Corelli estava residindo no endereço da "loja da moradia de Mme Dejean" (Diário do Rio de Janeiro, 03 ago. 1857).

No caso dos profissionais da escola, nas fontes pesquisadas, observa-se uma série de conexões entre o professor Pardal e seus colegas da mesma freguesia, algumas sinalizadas no capítulo I. José Bernardes Moreira, que passou a ocupar a segunda cadeira de Santa Rita criada em 1858, atuou com Pardal em bancas examinadoras e comissões de avaliação. Francisca Paula de Moraes e Lima, professora da escola de meninas da mesma freguesia. Josepha Thomazia da Costa Passos era casada com o filho de um ex-adjunto da escola de Pardal. João José Moreira, professor da freguesia de Santana, mas cuja escola, entre 1857 a 1877, ocupou prédio na Rua da Princesa, na freguesia de Santa Rita, foi signatário do Manifesto dos professores de 1871. Ele participava de comissões com Pardal, como a que causou polêmica por reprovar um compêndio para uso nas escolas, e ambos compunham mesa diretiva da Academia Pedagógica. $\mathrm{O}$ adjunto José Antônio Campos Lima teve o exame para ingresso no $3^{\circ}$ ano avaliado por Pardal e José Bernardes Moreira. O mesmo ocorre em relação às freguesias próximas. Luiz Thomaz de Oliveira, professor da freguesia da Candelária, também estava na mencionada comissão de avaliação de livro. Marcos Bernardino da Costa Passos professor da freguesia de Sacramento tinha sido adjunto de Pardal. Tais professores não apenas se conheciam, mas tinham conexões que se materializaram no movimento docente, na aprendizagem do ofício, na cultura material escolar por meio da aprovação ou rejeição de obras pedagógicas para adoção das escolas públicas. 
No universo de famílias que buscaram ou tiveram que submeter seus filhos e tutelados à escolarização no prédio da Rua da Imperatriz, n. ${ }^{\circ}$ 121, cabe indagar: quantos meninos eram e de onde vinham para aprenderem as primeiras letras na Escola de Santa Rita? O primeiro mapa de matrícula, constando uma listagem de alunos da $1^{\text {a }}$ Escola de Santa Rita, foi localizado durante a pesquisa no AGCRJ data de julho de 1854. Não obstante as "Providências" de 1836 terem instituído anteriormente a organização de mapas como parte da burocracia escolar, a data do documento coincide com o ano da reforma da instrução na Corte em 1854 que determinou a obrigatoriedade da confecção de mapas de matrículas, sendo alguns com periodicidade trimestral e outro anual, a serem remetidos aos delegados da instrução de suas respectivas freguesias. No fim de cada trimestre os professores deveriam remeter "um mapa nominal dos alunos matriculados, com declaração de sua frequência e aproveitamento; e no fim do ano um mapa geral, compreendendo o resultado dos exames, e notando d'entre os alunos os que se fizeram recomendáveis por seu talento, aplicação e moralidade" (Art.66).

Importante peça para compreender o funcionamento escolar, os mapas de frequência, segundo Vidal (2008 , p. 43), eram um expediente similar aos mapas estatísticos que "despontaram, no início do século XIX, como dispositivo de governo, fundando-se em uma prática escriturística que, ao mesmo tempo, nomeava, classificava e hierarquizava os sujeitos e a realidade social”. Para Vidal, ao preencherem os mapas, os professores renovavam táticas de sobrevivência profissional, por meio das estratégias de escrita, garantindo a manutenção das escolas e o recebimento de salários. Também construíam "identidades ao trabalho docente e à infância escolarizada”, normatizando o exercício profissional e o aluno. Vidal também elenca um conjunto de reflexões possíveis a partir dos mapas:

[...] a análise dos mapas de frequência permite desenhar aspectos da experiência coletiva de ser professor na primeira metade do século XIX, ela, também, oferece-nos pistas sobre a experiência individual e coletiva de ser aluno - as burlas realizadas; as sociabilidades; as dificuldades de aprendizagem, entre outros -, e das intricadas relações entre escola e sociedade no período (Vidal, 2008, p. 65).

Com intuito de apreender tais questões, bem como de acompanhar a movimentação de matrículas e dos sujeitos escolares da $1^{\text {a }}$ escola de meninos da freguesia, selecionei um conjunto de cinco mapas trimensais que datam de $10 / 01 / 1855$ até $25 / 01 / 1856$ - percorrendo aproximadamente o transcurso de 
um ano. Os mapas contêm os campos: nomes dos alunos, idade, nome dos pais ou encarregados, naturalidade, endereço, data da matrícula, grau de instrução na entrada, grau de instrução na atualidade, inteligência, aplicação, moralidade, faltas no trimestre e observações. A partir das informações organizei uma listagem geral como o nome de todos os alunos matriculados (apêndice 6). Foi possível observar que, no decorrer de um ano, houve um total de 202 matrículas. No gráfico a seguir, podemos visualizar o total de alunos de cada mapa. Para efeito de comparação, os dados de 1854 e de 1857 também foram incluídos no gráfico.

Gráfico 2 - Total de alunos em cada mapa de matrícula

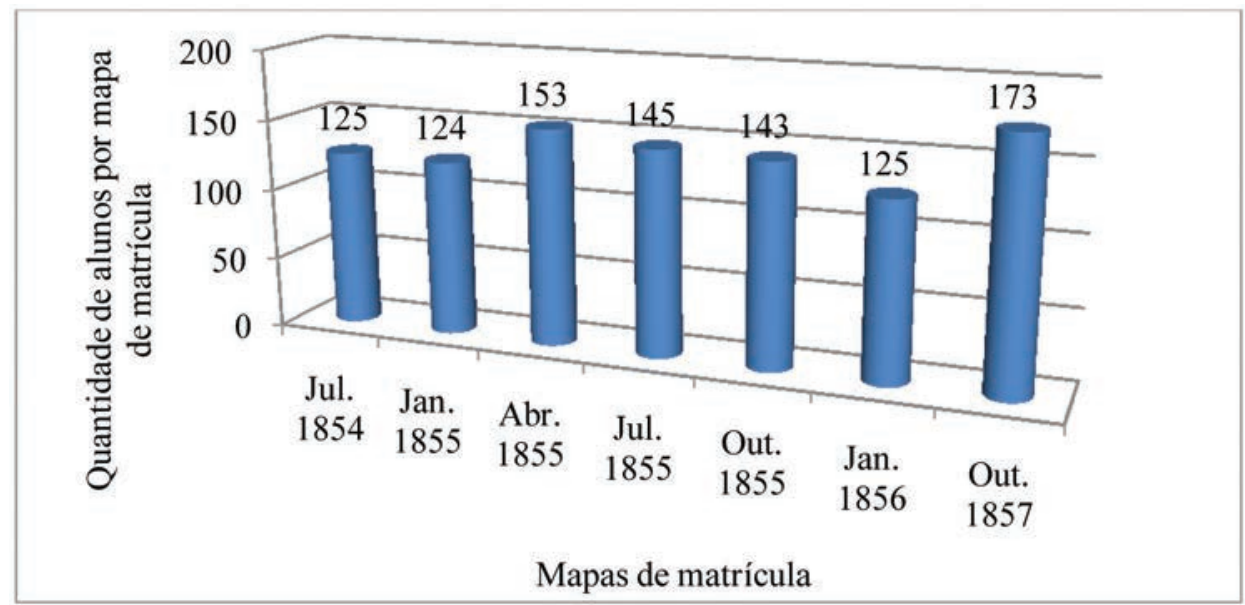

Fonte: Gráfico elaborado pela autora com base nos mapas de matrícula de 1854 a 1857 localizados no AGCRJ.

Observa-se que ocorreu uma oscilação no número de matrícula, mas o total se manteve acima dos 120 alunos em cada ano ou trimestre. Um número significativamente alto para uma escola que não funcionava em prédio próprio e que mesclava o ensino mútuo e o simultâneo. 
Figura 19 - Mapa trimensal de matrícula da Escola Pública de Santa Rita de 12 de julho de 1855 (AGCRJ)

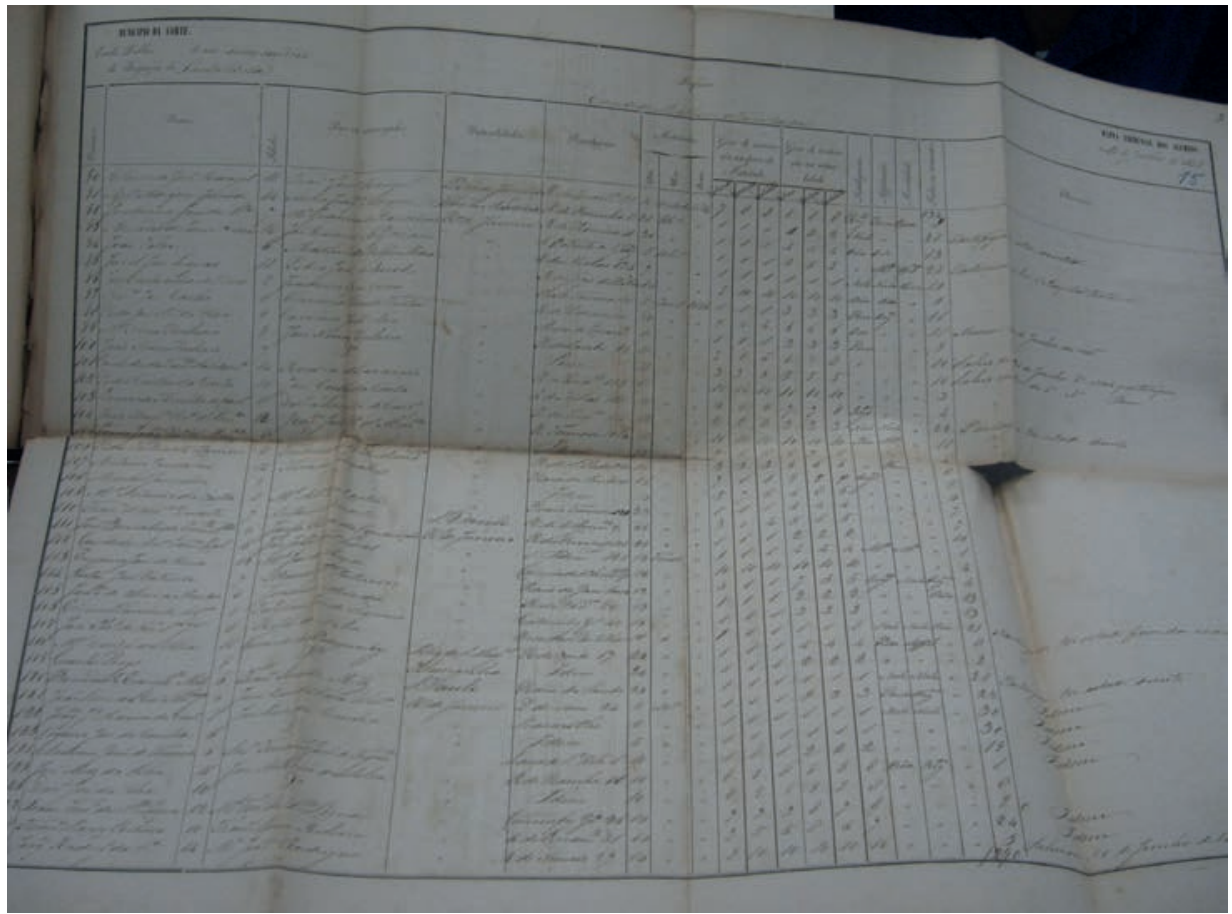

Fonte: Foto da autora.

A faixa etária dos alunos listados se estendia dos 5 aos 15 anos de idade, distribuídos conforme indicado no gráfico 3. Corresponde ao intervalo de idade permitido pelo Regulamento de 1854: "Art. 70. Às lições ordinárias das escolas não poderão ser admitidos alunos menores de 5 anos, e maiores de 15.” 
Gráfico 3 - Idade dos alunos no ato da matrícula entre janeiro de 1855 e janeiro de 1856

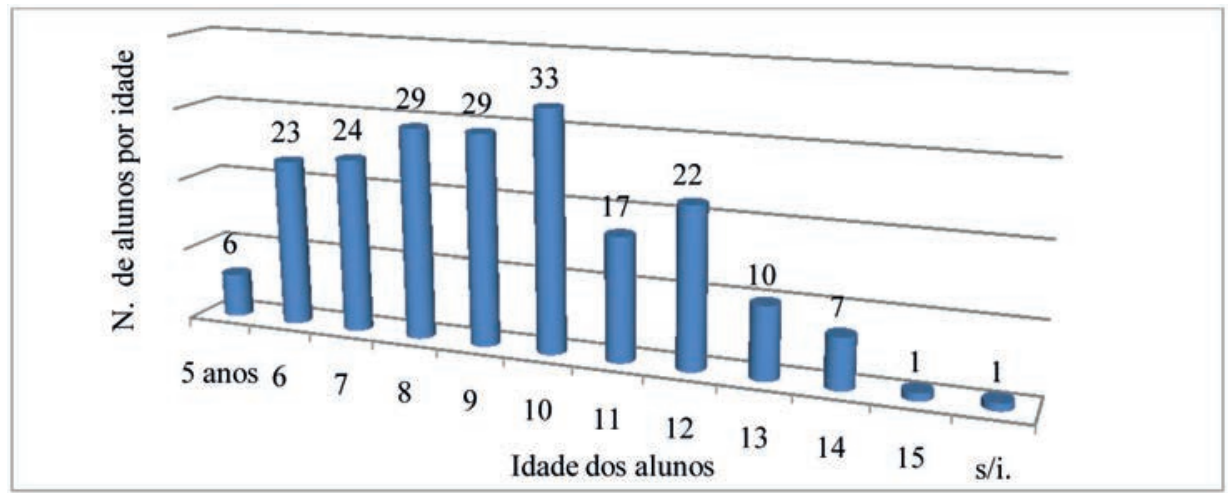

Fonte: Gráfico elaborado pela autora com base nos mapas de matrícula de 1854 a 1857 localizados no AGCRJ.

Havia uma concentração maior de alunos entre seis e doze anos de idade, sendo a mais alta a faixa etária dos dez anos, e uma queda entre os mais novos e os mais velhos. Pode-se cogitar um retardamento na iniciação da escolarização, bem como sua interrupção, em razão da iniciação ou participação das crianças no mundo do trabalho ou das famílias não verem necessidade na continuidade dos estudos, após a aquisição dos rudimentos da leitura e da escrita, conforme sugerido pelos relatos dos professores.

Faria Filho e Bertucci (2009), em uma análise das contribuições de Thompson para uma história social da escolarização, assinalam que "as idades escolares, inventadas e reinventadas sucessivamente pela escola, remetem continuamente para os novos modos de produção de identidades sociais e emergência de novas tecnologias de controle das diversas gerações e das relações entre gerações.” (p. 20). Alertam que a recusa da frequência, o encurtamento ou o alargamento da permanência na instituição escolar "não podem ser vistos apenas como o resultado da ação dos imperativos escolares, mas também como uma forma como os alunos e suas famílias interpretam a importância da escola no conjunto de suas vidas" (p. 19). Igualmente ressaltam que a "experiência de ir para a escola nunca foi a mesma para meninos e meninas, alunos/as e professores/as" (p. 19). Segundo os autores, para os meninos, o tempo escolar "compete com o tempo livre das brincadeiras ou o trabalho fora de casa”, e, no caso das meninas, "concorre com o aprisionamento no trabalho da casa sob supervisão direta ou indireta da mãe" (p. 19). 
A maior parte dos alunos iniciou os estudos em 1854 e em 1855. Nesse grupo havia meninos de idade entre 5 e 15 anos, sendo cinco com 14 anos e um com 15 anos de idade. Mas, alguns meninos faziam o trajeto em direção à escola da freguesia havia vários anos. Três alunos tinham matrícula desde 1849 , ou seja, estavam na listagem havia pelo menos seis anos. Eram os dois irmãos de sobrenome Gomes da Costa e o menino Alfredo Candido Pereira de Souza.

O que seis anos de matrícula em uma escola poderia indicar? Todos os três alunos haviam iniciado os estudos na $1^{\text {a }}$ classe de leitura, de escrita e de contas. Amâncio Lourenço Gomes da Costa estava na $10^{\text {a }}$ e última classe quando saiu da escola, em 1855, e o motivo registrado no mapa era de que iria seguir estudos superiores. Era classificado como aluno de muita inteligência, boa aplicação e moralidade. Seu irmão, Vicente Lauro, com a mesma avaliação escolar, em 1858, aos prováveis 15 anos, tornou-se aspirante do Quartel da Companhia de Aspirantes a Guardas-Marinhas e depois soldado do Corpo de Artilharia de Mato-Grosso, quando sua mãe pediu sua baixa ao Ministério da Guerra, em 1860, como veremos adiante.

Alfredo de Souza, no mapa de 1856, era classificado como $9^{a}$ classe de leitura, $8^{\text {a }}$ de escrita e de contas, com regular inteligência e aplicação, e boa moralidade. Ele perdeu o pai (que era solteiro segundo jornais) em 1858 e tornou-se guarda do Corpo de Artilharia da Guarda Nacional. Os irmãos Gomes da Costa concluíram os estudos da escola primária e Alfredo, apesar de adiantado, não sabemos se fez o mesmo.

Os seis anos de escolaridade permitiram a Amâncio vislumbrar estudos superiores e a Vicente a carreira militar, aparentemente interrompida a pedido da mãe. Quanto a Alfredo, não foi possível localizar mais detalhes sobre suas ocupações, mas os anúncios de 1858, acerca de arremate do espólio de seu falecido pai, mostram que a família tinha vários escravizados, animais e móveis de valor, bem como as "taxas" das barreiras do comércio, barca de Ubá e Fonte do Desengano (apêndice 7).

Os Gomes da Costa apresentavam como endereço o Morro do Livramento e Alfredo Candido Pereira de Souza, a Rua da Pedreira da Conceição (depois se mudando para Rua Nova do Príncipe, ainda em 1855), áreas próximas à escola. No entanto, o perímetro da área de residência de alunos que buscavam a escola pública do professor Pardal era mais alargado, extrapolando os limites da própria freguesia de Santa Rita. 
A maior parte dos alunos morava nas imediações da escola e do Livramento, seja no próprio morro, na rua ou na ladeira que levam o mesmo nome. O Livramento aparece como endereço de 24 meninos e 17 residências - o endereço não corresponde ao número de residências, pois alguns eram irmãos ou parentes. Entre as ruas do entorno da escola, a Rua da Princesa agregava mais meninos (16), com dez residências. A partir da listagem, também organizei um quadro com os logradouros registrados, indicando quantas residências estavam situadas em cada um deles, permitindo entender a distribuição geográfica desse grupo de alunos, pais e encarregados.

Quadro 15 - Ruas das residências organizadas por ordem de quantidade de alunos

\begin{tabular}{|c|c|c|c|}
\hline & Logradouro & $\begin{array}{l}\mathrm{N}^{\circ} \mathrm{de} \\
\text { alunos }\end{array}$ & $\begin{array}{l}\mathrm{N}^{\circ} \text { de } \\
\text { residên- } \\
\text { cias }\end{array}$ \\
\hline 1 & Rua da Princesa & 16 & 10 \\
\hline 2 & $\begin{array}{l}\text { Rua do Livra- } \\
\text { mento }\end{array}$ & 9 & 5 \\
\hline 3 & $\begin{array}{l}\text { Morro do Livra- } \\
\text { mento }\end{array}$ & 8 & 6 \\
\hline 4 & $\begin{array}{l}\text { Rua da Impe- } \\
\text { ratriz }\end{array}$ & 7 & 6 \\
\hline 5 & Rua da Saúde & 7 & 4 \\
\hline 6 & $\begin{array}{l}\text { Rua do Jogo da } \\
\text { Bola }\end{array}$ & 7 & 4 \\
\hline 7 & $\begin{array}{l}\text { Rua da Alfan- } \\
\text { dega }\end{array}$ & 6 & 5 \\
\hline 8 & $\begin{array}{l}\text { Rua da Harmo- } \\
\text { nia }\end{array}$ & 6 & 3 \\
\hline 9 & Rua das Violas & 6 & 5 \\
\hline 10 & Rua da Pedreira & 5 & 5 \\
\hline 11 & Rua da Prainha & 5 & 4 \\
\hline 12 & $\begin{array}{l}\text { Ladeira do } \\
\text { Livramento }\end{array}$ & 4 & 4 \\
\hline 13 & Praia da Saúde & 4 & 3 \\
\hline
\end{tabular}

\begin{tabular}{|c|l|c|c|}
\hline & Logradouro & $\begin{array}{l}\mathbf{N}^{\circ} \text { de } \\
\text { alunos }\end{array}$ & $\begin{array}{l}\mathbf{N}^{\circ} \text { de } \\
\text { residên- } \\
\text { cias }\end{array}$ \\
\hline 14 & Rua da Vala & 2 & 2 \\
\hline 15 & Rua de S. Pedro & 2 & 2 \\
\hline 17 & $\begin{array}{l}\text { Rua de S. Pedro } \\
\text { (C.N.) }\end{array}$ & 2 & 2 \\
\hline 18 & Rua do Aljube & 2 & 2 \\
\hline 19 & Rua do Fogo & 2 & 2 \\
\hline 20 & Rua do Nuncio & 2 & 1 \\
\hline 21 & $\begin{array}{l}\text { Rua do Pedre- } \\
\text { gulho }\end{array}$ & 2 & 1 \\
\hline 22 & Rua do Regente & 2 & 2 \\
\hline 23 & $\begin{array}{l}\text { Rua do S. dos } \\
\text { Passos }\end{array}$ & 2 & 2 \\
\hline 24 & $\begin{array}{l}\text { Rua do Saco } \\
\text { d'Alferes }\end{array}$ & 2 & 1 \\
\hline 25 & Rua do Saco & 2 & 2 \\
\hline 26 & $\begin{array}{l}\text { Travessa das } \\
\text { Mangueiras }\end{array}$ & 2 & 1 \\
\hline
\end{tabular}




\begin{tabular}{|c|c|c|c|c|c|c|c|}
\hline 27 & Rua de S. Diogo & 4 & 4 & 48 & $\begin{array}{l}\text { Campo de S. } \\
\text { Cristóvão }\end{array}$ & 1 & 1 \\
\hline 28 & Rua do Príncipe & 4 & 4 & 49 & $\begin{array}{l}\text { Escadinha do } \\
\text { Tijolo, Saúde }\end{array}$ & 1 & 1 \\
\hline 29 & $\begin{array}{l}\text { Beco das Parti- } \\
\text { lhas }\end{array}$ & 3 & 2 & 50 & $\begin{array}{l}\text { Ladeira de João } \\
\text { Homem }\end{array}$ & 1 & 1 \\
\hline 30 & $\begin{array}{l}\text { Catumby } \\
\text { Grande }\end{array}$ & 3 & 2 & 51 & Largo de S. Rita & 1 & 1 \\
\hline 31 & $\begin{array}{l}\text { Largo da Impe- } \\
\text { ratriz }\end{array}$ & 3 & 2 & 52 & Livramento & 1 & 1 \\
\hline 32 & $\begin{array}{l}\text { Rua da Can- } \\
\text { delária }\end{array}$ & 3 & 1 & 53 & $\begin{array}{l}\text { Morro de Paula } \\
\text { Mattos }\end{array}$ & 1 & 1 \\
\hline 33 & $\begin{array}{l}\text { Rua do Coito } \\
\text { (Rua do Costa?) }\end{array}$ & 3 & 3 & 54 & Pedra do Sal & 1 & 1 \\
\hline 34 & $\begin{array}{l}\text { Rua Estreita de } \\
\text { S. Joaquim }\end{array}$ & 3 & 2 & 55 & Praia do Saco & 1 & 1 \\
\hline 35 & Rua Formosa & 3 & 2 & 56 & $\begin{array}{l}\text { Rua da Lampa- } \\
\text { dosa }\end{array}$ & 1 & 1 \\
\hline 36 & $\begin{array}{l}\text { Rua Larga de } S . \\
\text { Joaquim }\end{array}$ & 3 & 3 & 57 & $\begin{array}{l}\text { Rua da Pedreira } \\
\text { Conceição (?) }\end{array}$ & 1 & 1 \\
\hline 37 & São Cristóvão & 3 & 1 & 58 & $\begin{array}{l}\text { Rua da Provi- } \\
\text { dencia }\end{array}$ & 1 & 1 \\
\hline 38 & $\begin{array}{l}\text { Beco de João } \\
\text { Ignacio }\end{array}$ & 2 & 1 & 59 & $\begin{array}{l}\text { Rua de S. Lou- } \\
\text { renço }\end{array}$ & 1 & 1 \\
\hline 39 & Gamboa & 2 & 2 & 60 & Rua de Sant'Ana & 1 & 1 \\
\hline 40 & Ilha das Cobras & 2 & 2 & 61 & $\begin{array}{l}\text { Rua do Bom-Jar- } \\
\text { dim }\end{array}$ & 1 & 1 \\
\hline 41 & $\begin{array}{l}\text { Largo da Prai- } \\
\text { nha }\end{array}$ & 2 & 2 & 62 & $\begin{array}{l}\text { Rua do Sabão } \\
\text { (C.N.) }\end{array}$ & 1 & 1 \\
\hline 42 & Lazareto & 2 & 1 & 63 & Rua do Sabão & 1 & 1 \\
\hline 43 & Mato Grosso & 2 & 2 & 64 & $\begin{array}{l}\text { Rua do SS Sacra- } \\
\text { mento }\end{array}$ & 1 & 1 \\
\hline 44 & Morro da Saúde & 2 & 1 & 65 & Rua dos Ourives & 1 & 1 \\
\hline 45 & $\begin{array}{l}\text { Morro do } \\
\text { Valongo }\end{array}$ & 2 & 1 & 66 & Rua do Aterrado & 1 & 1 \\
\hline 46 & $\begin{array}{l}\text { Praia da Gam- } \\
\text { boa }\end{array}$ & 2 & 2 & 67 & $\begin{array}{l}\text { Travessa do } \\
\text { Mato Grosso }\end{array}$ & 1 & 1 \\
\hline 47 & Praia Formosa & 2 & 2 & 68 & Sem endereço & 12 & - \\
\hline
\end{tabular}

Fonte: Quadro elaborado pela autora com base nos mapas de matrícula de 1854 a 1857 localizados no AGCRJ. 
Para compreender melhor a distribuição das residências fiz um agrupamento por proximidade de logradouros, no qual registro o nome dos alunos, pais e encarregados, bem como a numeração dos endereços, com o intuito de observar possíveis relações de vizinhança (apêndice 7). A seguir apresento no mapa um esquema de agrupamento de residências que permite visualizar melhor essa distribuição geográfica dos alunos.

Figura 20 - Esquema de agrupamento dos endereços dos alunos a partir da Planta da Muito leal e heroica cidade de São Sebastião do Rio de Janeiro de 1852

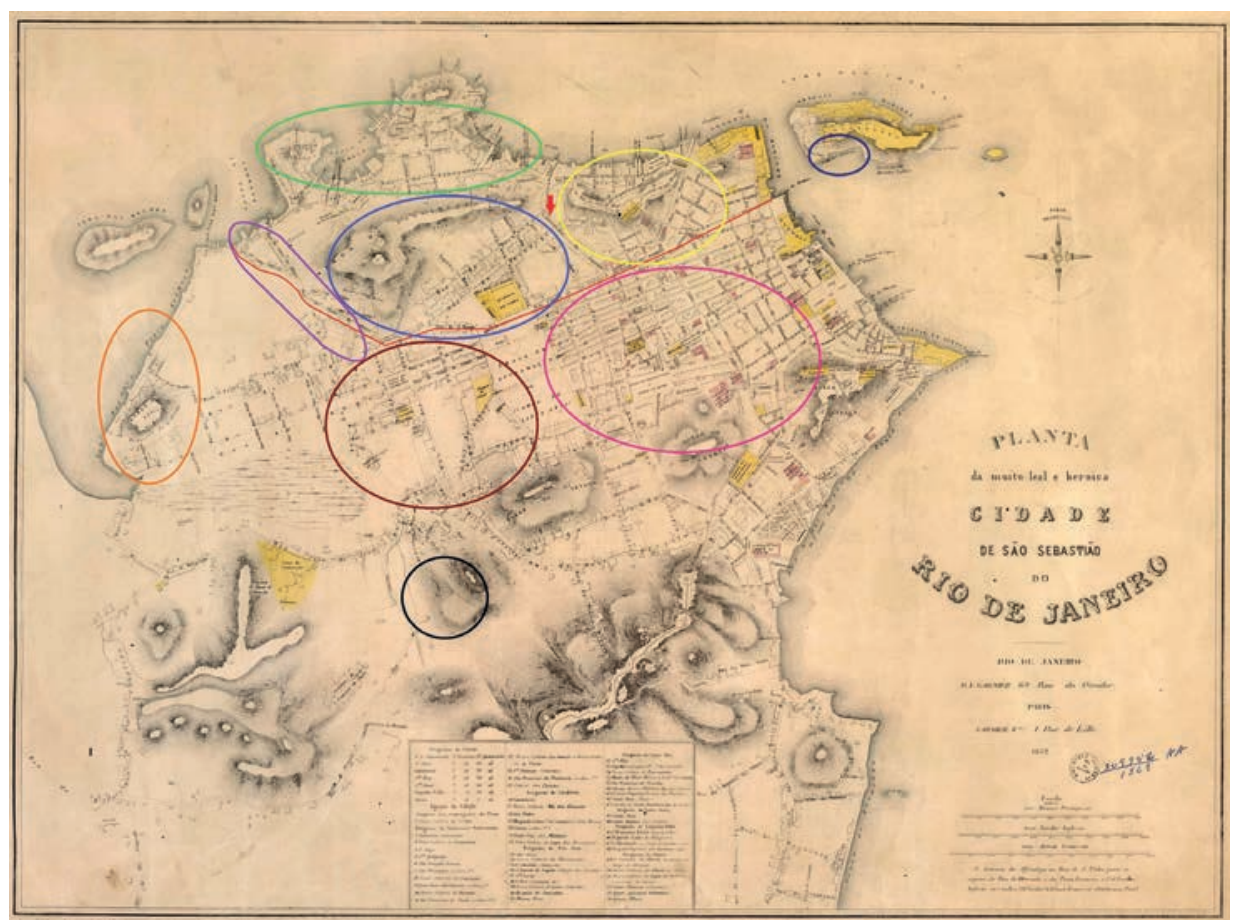

Fonte: Biblioteca Nacional.

Legenda - Número de alunos por localidade

Imediações do largo da Imperatriz e Morro do Livramento: 59 alunos

Região situada entre as ruas de São Joaquim e Morro de Santo Antônio: 38

Região em torno do Morro da Conceição: 29

Região Portuária em frente ao Morro do Livramento: 26

O Região da Cidade Nova: 15

O Região do Saco do Alferes: 6

Praia Formosa: 2

O Ilha de Cobras: 2

O Morro de Paula Mattos: 1

Obs.: Um total de 24 alunos não entrou nesse esquema. Nove alunos por residirem fora da área mapeada; três por residirem em rua não localizada; e outros doze alunos não tiveram seus endereços registrados. 
O que mais se sobressai na distribuição das residências, e que pode ser visualizado pelo esquema apresentado, é o fato da escola de Santa Rita receber vários alunos da sua freguesia, mas também de toda a região central da cidade e até mesmo de áreas mais afastadas, que não estão contempladas nesse mapa. Importa ressaltar que havia mais cinco escolas públicas para meninos nessa parte da cidade - as das freguesias de Santana, Sacramento, Candelária, São José e Santo Antonio (criada em 1855) no período retratado. Poderia esta situação sinalizar uma preferência dos pais pela escola do professor Pardal em relação às outras?

Figura 21 - Distritos administrativos em 1870

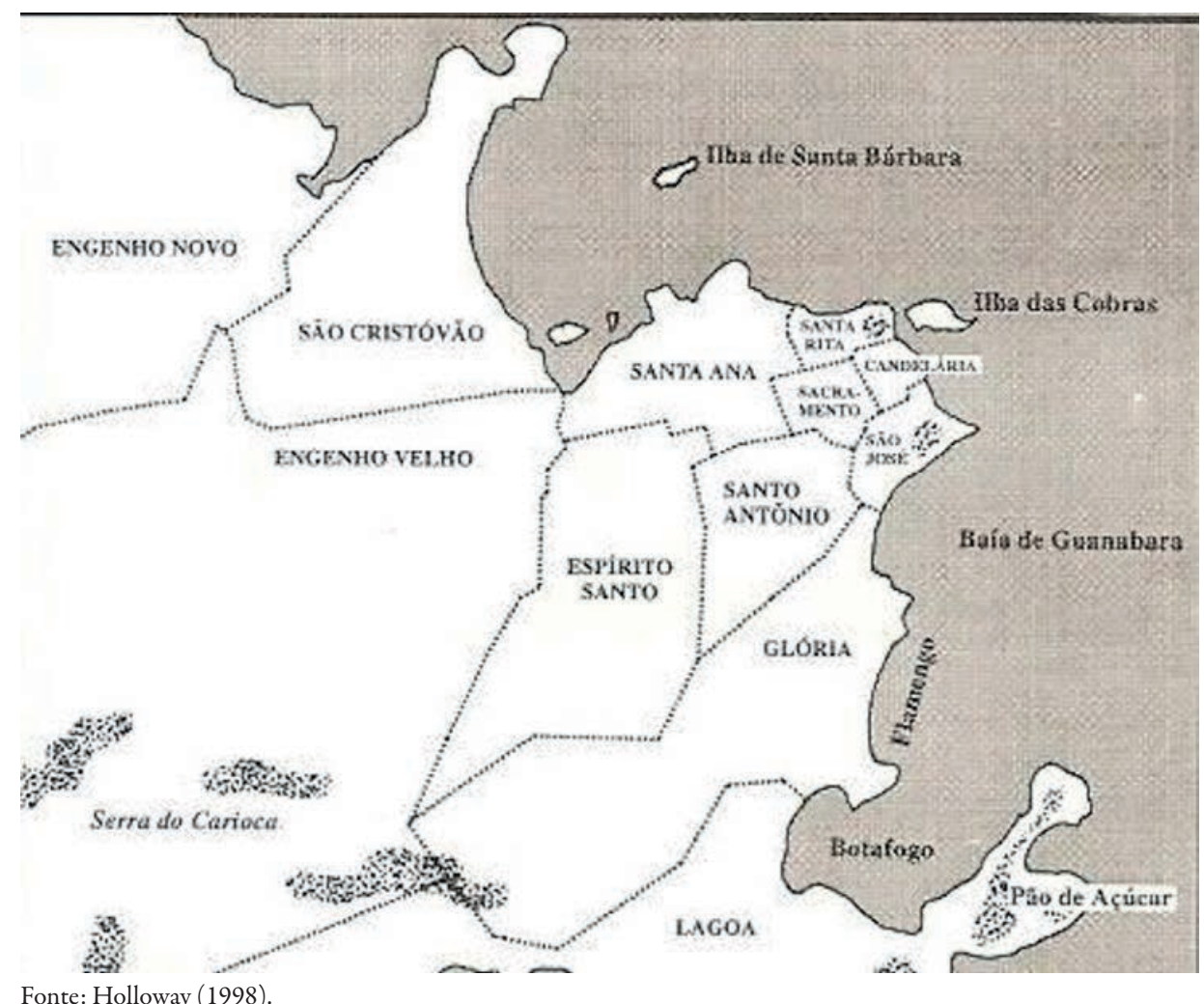

A suposição de que as famílias procediam a uma escolha da instituição que iria ensinar aos seus filhos as primeiras letras é uma variável a ser considerada e nos aponta importantes questões sobre o papel das famílias na escolarização dos filhos. A existência desse tipo de prática na Corte está assinalada no relatório 
da "Comissão visitadora das escolas públicas e estabelecimentos particulares" que alegava, entre as razões apresentadas para justificar a realização das aulas em uma só sessão, que:

Nem sempre são os meninos de cada freguesia os que frequentam as escolas das mesmas; os pais conforme as simpatias, as relações, ou a confiança que têm num ou n’outro professor, para ele é que mandam seus filhos, às vezes de muito longe, e para estes é penoso percorrer 4 vezes por dia essa grande distância debaixo de sol ou de chuva, acontecendo, por conseguinte, que deixarão de ir, as mais das vezes, à aula da tarde (Relatório da IGIPSC, anexo 7, 1873, p. 54).

Munhoz (2012) observou fenômeno similar em Paranaguá, onde famílias optaram por transferir seus filhos quando houve a criação de uma segunda cadeira. A autora trabalhou com a hipótese de que a preferência das famílias pelo novo professor se deu pelo fato dele ser um padre, uma vez que a religião se associava a uma expectativa de qualidade de ensino. Nesse sentido, a postura das famílias também contribui para compreendermos a posição da escola na sociedade. Seria a condição da escola dirigida por Pardal atraente para os responsáveis pelos alunos que, por exemplo, residiam na freguesia de São Cristóvão, Santo Antônio e da região chamada de Saco do Alferes, que eram áreas distantes da escola?

Por outro lado, observam-se muitos endereços próximos e a proximidade dos números de certas casas em um mesmo logradouro indica que vários alunos eram vizinhos. João Miguel Salgueiro (7 anos), Simeão Joaquim do Nascimento (10), Alfredo da Sa Serra (6) e o lisboeta Antonio M. da Silveira (10) tinham como endereço a Ladeira do Livramento, nos números 2, 11, 13 e 15. Percebe-se que três deles moravam praticamente um ao lado do outro. Infelizmente, não foi possível localizar mais informações acerca dos responsáveis por meio da pesquisa nos periódicos, apenas o rumo tomado por alguns alunos.

$\mathrm{Na}$ rua da escola, da Imperatriz, moravam o baiano Agostinho Borges da Cunha (7 anos), Jesuíno José Pires (11), Manoel Machado Fagundes (8), Euclides da Fonseca Saldanha (14), os meninos Leopoldo Augusto da Câmara Lima (9) e Leopoldo Thimoteo de Carvalho (8), nos números 2, 17, 30, 113 e 114, e também João Baptista d'A. Coelho ( 6 anos) cujo endereço aparece sem indicação de número, mas que provavelmente deveria ser o número 107 , onde funcionava o armazém de secos e molhados de seu responsável, João Baptista Coelho. O já mencionado pai de Manoel Machado Fagundes também possuía 
armazém de secos e molhados no mesmo endereço da residência. $\mathrm{O}$ responsável por Leopoldo Lima e Leopoldo de Carvalho era "fiel" de obras da Câmara Municipal e depois se tornou escriturário da Diretoria das obras municipais, e o pai de Agostinho Borges da Cunha era ferreiro, trabalhava no Arsenal de Guerra, mas veio a falecer no final de 1855. Comerciante, funcionário público e ferreiro. Três atividades distintas de sujeitos que moravam na mesma rua, cujos filhos frequentavam a mesma escola.

O logradouro com mais alunos em situação de vizinhança é a Rua da Princesa (dos Cajueiros), onde residiam dezesseis alunos (ver apêndice 8). Ela começava na Rua da Imperatriz e terminava na Rua Nova do Príncipe. Os alunos Antônio Cosme Monteiro (5 anos); Joaquim José Alves (9), Firmino de Aquino Brandão (11) e Manoel Theodoro de Lima Ferreira (8) moravam nos números 5, 19, 22 e 24; João José Barbosa (7) e Antonio Bernardes de Monteaury (11) nos números 38 e 40; José Bernarbé do Espírito Santo no número 105; os irmãos Francisco José Ferreira Villaça (7) e João Ferreira Villaça (6), no número 150; os irmãos Francisco da Rocha Paranhos (10) e João Silvestre da Rocha Paranhos (9) no 154, e os cinco irmãos Ferreira Leal no número 156. A ocupação das quatro famílias identificadas também era bem diversificada. Havia procurador, despachante de casa comercial, contínuo (administração pública) e proprietário de pedreira, por exemplo.

Outros exemplos de residência na mesma rua que chamam atenção são aqueles em que o próprio número da casa era igual. Como era o caso dos alunos Zacharia José de Carvalho, Francisco Alves da Silva e André Avelino de Carvalho, cujo logradouro era a Rua do Jogo de Bola - que segundo Rios Filho (2000) possuía esse nome em razão dos jogos praticados por "capoeiras e vagabundos". A residência dos três ficava no número 8 , mas tinham responsáveis diferentes. Seria possível cogitar que o endereço fosse um cortiço? Embora tivessem responsáveis diferentes (Leonarda Mariana da Silva, Delfino José da Silva, João José de Carvalho), Zacharia e André possuíam o mesmo sobrenome que o terceiro responsável, e Francisco o mesmo que os dois primeiros, sugerindo que fossem da mesma família. Apesar do estigma trazido por Rios Filhos acerca dos seus frequentadores, os mapas de matrícula de Pardal, que registram mais quatro alunos residentes nessa rua, informam que os meninos tinham boa moralidade, com exceção de José dos Santos, considerado “irregular” pelo professor.

A rua da escola desembocava na Rua Estreita de São Joaquim onde, no número 28, residiam os alunos Francisco Lopes Barbosa ( 5 anos) e João Francisco Coelho Pereira (12) e o que chama atenção aqui é que o responsável por Francisco 
era um padre de mesmo nome, Francisco Lopes Barbosa, e a responsável por João era uma mulher, Deolinda Rosa. O endereço era de propriedade do próprio padre. Ele comprou metade do sobrado de Thomaz Alves de Souza Bastos e de sua mulher em um processo de venda iniciado em 1842 (Diário do Rio de Janeiro, $19 \mathrm{dez} .1842$ ). O padre, que era vigário da Vila de Iguassu, onde também era vereador da Câmara Municipal, faleceu em 1855, conforme indica nota de arremate de três escravizados do seu espólio divulgado no Correio Mercantil (25 out. 1855). O arremate do sobrado na Rua Estreita da São Joaquim foi anunciado no ano seguinte no mesmo periódico (06 jun. 1856). O aluno Francisco saiu da escola, alegando ir para outra da freguesia, e João faleceu em setembro de 1855.

Em outro caso, dois alunos, Sergio Neves Gonçalves (8 anos) e Carlos Rodrigues de Faria (6), tinham responsáveis diferentes e residiam no número 125 do Largo da Imperatriz, mesmo endereço em que anos mais tarde seria instalada a escola, transferida do Largo da Imperatriz, n. ${ }^{\circ}$ 121. Uma busca no Almanak Laemmert pelo número 125 mostra que várias pessoas já haviam apresentado o lugar como sua residência. Por outro lado, o acompanhamento da trajetória de vida de Luiz Rodrigues de Faria, responsável por Carlos Rodrigues de Faria, mostra que ele mudava de endereço com muita frequência, apesar de trabalhar em ocupações que lhe davam certa estabilidade: amanuense do Consulado da Corte e depois, escrivão do depósito da Marinha.

Casos como o do aluno Perciliano das Chagas Oliveira (7 anos), cujo responsável era o carpinteiro Leopoldino das Chagas Oliveira, que residia na Rua do SS. Sacramento, n. ${ }^{\circ}$ 4, mesmo endereço de Eusébio de Queiroz, inspetor da Instrução, e de outros endereços que coincidem com os de estabelecimentos divulgados no Almanak Laemmert - como o do aluno Luis Giraud, cujo responsável era Giraud Henrique, que residia no mesmo número que o médico Soares Ribeiro e seu filho, tesoureiro das alfaias, na Rua dos Ourives, n. ${ }^{\circ} 25$-, também chamam a atenção e podem indicar o tipo de relações, posições sociais e agências que tais sujeitos possuíam na cidade.

O campo "residência" dos mapas nos permite observar questões que mostram a complexidade da sociedade da época. O processo de escolarização e a necessidade de aprendizagem das primeiras letras faziam conviver sob o mesmo teto, diariamente, durante algumas horas, os moradores de uma rua conhecida pela capoeira e vadiagem, os tutelados de um padre que possuía escravizados, os filhos de comerciantes, de artesãos e de funcionários públicos de baixo escalão. A variedade de ocupações desse conjunto de responsáveis, tratada brevemente 
nessa parte que visa compreender a distribuição geográfica dos alunos, sinaliza algumas hipóteses a serem exploradas no próximo item.

\section{Encarregados da matrícula, sujeitos da cidade}

Uma análise das famílias dos alunos torna-se indispensável para observar a dinâmica do local e da escola. A investigação em torno das ocupações, atividades e de outros dados diversos acerca dos pais ou encarregados dos alunos permite examinar a maneira como as famílias se inseriam na sociedade e como essa inserção levou-os a buscarem escolarização para os filhos ou tutelados. Ao abordar novos sujeitos e problemas da micro-história italiana, Espada Lima discute como a família se tornou eixo central de análise na compreensão da sociedade camponesa. Em que pese a diferença da realidade no caso brasileiro, as discussões trazem contribuições para este estudo. Questionar os modelos e superar os estudos das famílias como eram realizados pela chamada demografia histórica, segundo Lima, consiste numa dessas reflexões para as quais seria preciso compreender como os ciclos familiares ligavam-se ao ciclo de desenvolvimento e reprodução da sociedade. Assim, não era a família como instituição, "núcleo biológico", que interessava para a análise histórica, mas como um "núcleo de um sistema de relações” (Lima, 2009).

Com intuito de compreender uma parte das histórias de vida dos alunos, familiares e encarregados e seus "sistemas de relações", igualmente procurei rastrear o "fio do nome" (Ginzburg, 1991), utilizando, inicialmente, o Almanak Laemmert. Posteriormente, com o acesso aos periódicos do século XIX de modo digitalizado pela Biblioteca Nacional, foi possível ampliar as fontes e obter maior número de dados. Para identificar os indivíduos foi imprescindível realizar o cruzamento das informações obtidas nos jornais com aquelas fornecidas pelos mapas de matrículas, como idade, endereço e naturalidade. Em contrapartida, o enorme quantitativo de dados referentes a um mesmo nome - mas não necessariamente a mesma pessoa - prejudicou a identificação de alguns sujeitos. Assim, apesar do rastreamento do nome de um universo de quase 100 famílias, várias não foram incluídas no quadro de ocupações e atividades pela dificuldade de confirmação da identidade (apêndice 7).

O procedimento de rastrear nomes impôs a reflexão de outra problemática: as práticas de nomeação no Brasil do século XIX. Segundo Rowland, em ensaio do caso português, as práticas de nomeação possibilitavam que os nomes adquirissem um significado, contribuindo para o estabelecimento de uma iden- 
tidade social diante de outras pessoas ou grupos. $\mathrm{O}$ autor afirma, apoiado nos estudos de Vasconcellos (Antroponimia Portuguesa, 1928), que "o nome passa a ter simultaneamente uma dimensão social e uma dimensão moral, articulando as identidades pessoal e social dos indivíduos e contribuindo, assim, para a constituição social e moral da pessoa" (2008, p. 18).

Rowland destaca que a Contra-Reforma Católica e o Concílio de Trento tiveram participação acentuada nos processos de nomeação na Europa. Ao tentar regulamentar o sacramento do matrimônio, foi estipulado que cada pároco deveria manter um livro de registro de batismo e um de matrimônio. Segundo ao autor, quando a igreja instituiu "um registo nominativo de todos os seus paroquianos, tendo em vista a sua fiscalização e identificação genealógica, acabou por dar a todos os nomes um carácter público e contribuiu para a padronização das práticas de nomeação" (2008, p. 32).

No entanto, apesar da tentativa de padronização dos registros de batismo e casamento, Monteiro (2008), em estudo sobre os sistemas de transmissões de nomes nas elites em Portugal, aponta que os sobrenomes usados em Portugal eram aqueles considerados mais importantes. $\mathrm{O}$ autor menciona a que a única disposição legal existente era as Ordenações do Reino de Portugal (compilação de 1603, Filipinas), que vigorou até o século XIX tanto em Portugal quanto no Brasil:

[...] o assunto era aflorado, concretamente no título 92 do livro 5, intitulado "Dos que tomam insígnias de armas, e dom, ou apelidos, que lhes não pertencem”. Aí se estipulava, de permeio com muitas outras disposições, que se podiam tomar as armas do pai ou da mãe "e se quiserem tomar somente [estremes] as armas da parte de suas mães, podê-lo-ão fazer”, admitindo-se também que alguém fosse chefe de mais do que uma linhagem, o que pressupunha que, pelo menos de uma delas, o fosse por via feminina (2008, p. 50, aspas do autor).

Monteiro relata que tal prática chocava famílias que vinham de países em que os nomes se transmitiam apenas por via masculina e cita um relatório diplomático francês de 1864, no qual consta a surpresa com o fato de que fidalgos portugueses usavam o nome de suas mães quando eram melhores.

E, poucos anos volvidos (1701), registra-se num escrito inglês que se reporta à população portuguesa em geral: "quando casa, a mulher não toma o nome do marido, antes neste particular existe uma grande liberdade para que as pessoas 
tomem os nomes que lhes agradarem e, por vezes, dois irmãos do mesmo pai e mãe têm apelidos diferentes" (2008, p. 50, aspas do autor). ${ }^{2}$

O autor também ressalta que as mulheres nunca "tomavam o apelido do marido”, pois não era prática na elite aristocrática portuguesa. Prática que parece também se dar no grupo investigado neste estudo. A maior parte do conjunto de responsáveis pelos alunos da escola de Santa Rita era formada por homens, mas havia uma significativa presença de mulheres (55), todavia os mapas de matrículas não registraram os sobrenomes de muitas delas.

Monteiro também remete ao caso brasileiro, uma vez que o mesmo padrão poderia ser encontrado nas famílias paulistas dos séculos XVI, XVII, XVIII, com base na genealogia reunida por Pedro Tasques de Almeida Leme (1714[?]-1777):

Num total de 645 casamentos com dois ou mais filhos dos quais se conhecem os sobrenomes, os que produziram para cima de 3800 descendentes legítimos, observamos que apenas em $8,2 \%$ dos casos todos os filhos partilhavam o mesmo sobrenome ou conjugação de sobrenomes. Ou seja, em quase $92 \%$ tinham conjugações de apelidos diferentes e em mais de três quartos do total não tinham sequer um apelido em comum. As elites paulistas partilhavam, assim, de forma notória, o modelo de comportamento das elites reinóis. Pode sustentar-se, assim, que, nessa matéria, os modelos portugueses foram transpostos e retomados pelas elites do Brasil colonial (p. 52).

Apesar de o estudo ser, sobretudo, acerca das famílias das elites, o autor traz algumas questões para os casos populares. Uma das discussões era como nomes de famílias das "mais seletas fidalguias" se tornaram comum na população.

O sobrenome podia ser tomado de uma alcunha (em gerações ulteriores eventualmente transformado em apelido), ter uma origem toponímica (o que parece ser frequente até muito tarde), ser constituído por um segundo nome próprio, ter uma base patronímica ou, por fim, retomar apelidos, tomados dos progenitores, dos padrinhos ou até (no caso de criados ou de escravos) do senhor (p. 54).

${ }_{2}$ A citação entre aspas feita por Monteiro foi extraída de Cox, Tomas e Macro, Cox. Relaçâao do Reino de Portugal, 1701 (coord. de Maria Leonor Machado de Sousa). Lisboa: Biblioteca Nacional, 2007, p. 280. 
A mudança nas práticas de nomeação em Portugal começou no século XIX, protagonizada pelos grupos familiares em processo de mobilidade social ascendente, mais abertos aos valores e comportamentos associados à cultura francesa. A emergência de um novo modelo reforçou a autoridade paternal, sem que as referências maternas desaparecessem (Monteiro, 2008).

O caso dos escravos e libertos também deve ser considerado como parte da lista de nomes da população matriculada nas escolas da Corte. Em estudo sobre práticas sociais e parentesco entre os escravos na fazenda de Santa Cruz no Rio de Janeiro, Carlos Engemann (2002, p. 96) destaca que "se os homens organizam seu espaço por meio de suas relações socioculturais, a expressão social dessa relação pode ter se dado pela troca de sobrenomes”. Alerta, ao discutir a adoção do sobrenome dos senhores pelos escravos, que "antes que se pense apenas na adesão ou devoção desses aos seus senhores, é possível postular que essa foi uma 'herança' tomada ao antigo senhor. Um nome, uma identidade no mundo luso-colonial” (p. 94, aspas do autor).

Tais reflexões trazidas por Rowland, Monteiro e Engemann tornam-se importantes para entender a dinâmica de nomeação das famílias, cujos filhos ou tutelados acham-se registrados nos mapas de matrículas, como o fato de que o último nome do filho não ser sempre o mesmo do pai, apesar da comprovação da paternidade - ou ao menos sua assunção - obtida por outras fontes. O próprio caso do professor Pardal se enquadra nesta questão, pois seu pai se chamava Matheus Henriques de Faria e sua mãe Elisa Vieira da Silva, podendo assinalar a adoção do sobrenome pertencente a alguém de importância para a família.

Outras vezes, a questão era o uso do mesmo nome completo por duas pessoas no interior da mesma família. O caso da família Ferreira era emblemático. O pai se chamava José Joaquim Ferreira Leal e os meninos registrados em seu nome eram: José Antonio Ferreira Leal, Antonio Joaquim Ferreira Leal, Joaquim José Ferreira Leal, João Antonio Ferreira Leal e Candido Antonio Ferreira Leal. Não bastasse a similaridade dos prenomes, durante a pesquisa sobre os rumos tomados pelo ex-aluno Antonio Joaquim Ferreira Leal, uma série de dados levantados pareceriam não fazer sentido. O problema apenas foi compreendido com o aprofundamento da investigação e com auxílio da nota no Diário do Rio de Janeiro da missa fúnebre do patriarca da família, José Joaquim Ferreira Leal (no qual constava o nome de pessoas da família e seu grau de parentesco) e das listas de qualificação de votantes de 1876 e 1877 . Na nota, consta que o patriarca tinha um irmão chamado Antonio Joaquim Ferreira Leal e ambos eram filhos 
de José Ferreira Leal. Portanto, havia o ex-aluno chamado Antonio Joaquim, que se tornou professor, e o seu tio homônimo, que era proprietário, e ambos constavam nas listas de votantes.

Nesse caso, as relações de parentesco puderam ser identificadas, mas o emprego do termo "encarregado" - no mesmo campo dos "pais" - nos mapas de matrícula torna ainda mais complexa a análise, pois sugere uma relação sem parentesco com o aluno matriculado. Pode-se cogitar que esse indivíduo fosse uma espécie de protetor, tutor ou mesmo alguém com posição privilegiada na sociedade, a quem os pais poderiam recorrer no intento de garantir uma vaga na escola desejada. Parece ser o caso do Visconde de Baependy - à época, deputado na Assembleia Geral Legislativa -, que consta no campo de pais ou encarregados duas vezes em referência a dois alunos estrangeiros, um da Alemanha, Carlos Prigs, e outro da Ilha de São Miguel (Açores), Manoel Correa da Silva. Por que um visconde se encarregaria da matrícula de dois meninos estrangeiros? Poderia ser ele um agenciador de menores nos moldes discutidos por Martinho (1992) em seu estudo sobre os caixeiros no Rio de Janeiro? A autora aponta que os agenciadores traziam meninos de fora, geralmente de Portugal, pagando suas passagens e mantendo-os em casa até que encontrassem trabalho em algum estabelecimento comercial. As passagens deveriam ser ressarcidas e havia uma cobrança de taxa. Os dois meninos foram matriculados na primeira classe, sendo possível que o alemão não soubesse português. Por outro lado, ter na lista de matrícula um encarregado com título de nobreza poderia representar, para um professor, alguma distinção, troca de favores e também evidenciar as conexões por ele estabelecidas.

No entanto, Carlos e Manoel não eram os únicos alunos estrangeiros. Embora, a grande maioria dos alunos fosse registrada no campo "naturalidade" como sendo do Rio de Janeiro e outros de São Paulo (3), Porto Alegre (1), Bahia (1) e Ceará (1), havia alunos de Lisboa (1), Porto (1), Ilha da Madeira (3), além da Ilha de São Miguel (1) e Alemanha (1), já mencionados. Martinho (1992) também assinala que alguns meninos vinham de Portugal já destinados a estabelecimentos de parentes. Na mesma esteira de reflexão, Vidal (2008b) afirma que, na segunda metade do século XIX, uma onda migratória de galegos e portugueses do Norte de Portugal se deu em direção à América Latina, tendo como um dos destinos, o Brasil. Apoiada em Alves (1994), Vidal igualmente assinala que até 1870 a idade de maior frequência dos emigrantes portugueses era de 13 e 14 anos e que boa parte se destinava às casas de comércio.

Desse modo, chama atenção o fato do aluno de Lisboa, Francisco Ferraz de Macedo (10 anos), ter como responsável Antonio Ferraz de Macedo, proprietário 
de armarinho; de Antonio Marques Junior (Ilha da Madeira), cujo responsável era Anna Joaquina Marques, residir em um endereço, Rua da Prainha, n. ${ }^{\circ} 8$, registrado no Almanak Laemmert como lugar onde também funcionavam três estabelecimentos - uma loja de fazenda e de roupas de João Ferreira da Cruz \& C., um armazém de fazendas de Manoel Joaquim dos Reis e um armazém de materiais para obra de Antonio Teixeira de Barros (Al, 1854); de Francisco Antonio Pereira (8 anos) e Manoel Francisco Pereira (10), ambos da Ilha da Madeira. Francisco teve como primeiro responsável Belmiro Borges Pereira e, posteriormente, Antonio Francisco Pereira, o mesmo encarregado de Manoel. O encarregado Belmiro apresenta como endereço nos mapas de matrícula a Rua da Alfândega, n. 38 que, conforme consta no Almanak Laemmert, em 1854, era a residência de E. Volckmar, negociante estrangeiro de importação e exportação e vice-presidente da Sociedade Alemã de Beneficência.

Entre os nomes registrados nos mapas de matrícula, cabem algumas observações acerca do caso de dois alunos. Um deles, de oito anos, estava sem o nome completo e, em cinco mapas, foi registrado apenas como "Amador", tendo como responsável Francisco José da Silva Santos. O outro, Isidoro Gomes de Faria, nos dois mapas de matrícula em que esteve presente, teve como único dado registrado seu nome completo, sem constar idade, pai, encarregado ou endereço. A ausência desses dados poderia apontar uma situação "irregular" na escola ou na sociedade, como, por exemplo, no caso de escravizados ou filhos de relaçóes ilícitas. O nome Isidoro Gomes de Faria foi localizado na lista de alunos externos que concluíram os estudos primários na escola do Arsenal da Marinha (Diário do Rio de Janeiro, 23 dez. 1864), mas não há nenhuma outra informação que permita confirmar tratar-se da mesma pessoa, embora, seja sugestivo pelo fato desse nome não ser muito comum.

O trabalho de rastreamento e de garimpagem dos nomes registrados nos mapas de matrícula podem ser vistos na sistematização feita no apêndice 7 . Nele apresento o conjunto de informações obtidas dos sujeitos pesquisados - alunos, pais e encarregados - como ofício, ocupação, participação em associações, cargos ocupados, atividades realizadas e um conjunto diversificado de dados a respeito da vida destes sujeitos.

No entanto, é importante problematizar o quadro de ocupações dos pais organizado a partir de fontes como o Almanak Laemmert e a imprensa periódica. Tomando de empréstimo uma reflexão de Espada Lima (2006) acerca da pesquisa de Giordano Levi, podemos observar que é um quadro incompleto e limitado 
na medida em que o Almanak, por exemplo, privilegiava os comerciantes, proprietários, funcionários da máquina administrativa do governo, associações e indivíduos com peso suficiente para ter seu nome publicado nas páginas desse veículo de propaganda. Mas, por outro lado, também permite "lançar luz sobre o universo de estratégias locais de poder e de relações clientelares” (2006, p. 253) que se pretende colocar em evidência neste estudo.

Ambos os veículos, conforme já assinalado, fazem parte de um processo de escrituração sobre o outro no século XIX e apontam os modos de inscrição dos sujeitos e sobre os sujeitos. Dessa forma é possível observar que os mais pobres ou membros das classes populares aparecem em relatos de crimes e processos, como o carpinteiro Leopoldino das Chagas Oliveira, como veremos ainda neste capítulo. Em torno dos mais abastados prolifera uma escriturística não só nos veículos, mas nas instâncias, como no caso do atuante funcionário público Domingos Thimoteo de Carvalho. Por outro lado, essa escriturística marca também os pertencimentos sociais, como no caso do ex-aluno Manuel Nunes Pinheiro, intensamente envolvido com atividades associativistas. Personagens que possuíam relações com a Escola Pública de Santa Rita e que permitem operar com três tipos sociais para compreensão da organização social da cidade e do poder no período, como veremos adiante.

O recurso da pesquisa na imprensa periódica permite ampliar as possibilidades de investigação, mas ainda assim apresenta certas restrições no que concerne à presença de nomes das classes populares. Uma delas sendo a dificuldade de confirmar a identificação dos sujeitos em alguns casos, como em autos de prisão em que as notas não traziam mais do que o nome completo como informação pessoal. Por causa da possibilidade de homônimos, notas restritas como essas foram descartadas da pesquisa.

Em razão disso, é preciso cautela na análise do resultado do levantamento, bem como evitar generalizações a respeito da configuração do grupo atendido pela escola. Os sujeitos identificados pela imprensa periódica constituem parte autêntica do corpo discente, porém não podem ser usados para determinar o caráter social, econômico e cultural do alunado como um todo, mas apenas em parte. Dessa maneira, devem ser considerados os relatos dos professores, delegados da instrução e demais agentes do governo, registrados na documentação encontrada em arquivos e relatórios a respeito da população atendida, como as famílias pobres que, por sua condição social, não se tornam objeto de registro na imprensa ou aparecem com poucas informações, por vezes imprecisas, o que 
impossibilita a confirmação da identidade. A frequência de alunos de origem pobre pode ser confirmada por meio de relatos e documentos, como, por exemplo, os vários ofícios enviados por professores contendo listas de crianças pobres para receberem vestuário e o relatório da "Comissão visitadora das escolas públicas” de 1873, no qual os relatores afirmam que:

Entre nós, em regra geral, os ricos pagam a um mestre que vem dar em casa o primeiro ensino a seu filho; o remediado manda os filhos para um colégio particular onde recebem a instrução primária e secundária; o pobre esse é que se utiliza da escola pública, e são justamente esses os meninos que não primam pela educação, e que poucas vezes encontram na família os elementos necessários para formação de um bom caráter moral e religioso (Relatório da Comissão, anexo 3 do Relatório da IGIPSC, p. 39).

No mesmo relatório, ao tratar do problema da divisão das aulas em duas sessões que faz com que os alunos não retornem para assistir a aula da tarde, alega-se que:

Para as famílias pobres, onde a mais restrita a economia é assunto de suprema necessidade, torna-se penoso dividir o jantar comum antecipando o dos meninos que tem de ir para a escola, acontecendo, pois, que ou estes deixam de frequentar a aula de tarde, ou irão para ela sem ter tomado a necessária refeição, o que lhes deve causar sérias perturbações de saúde (Relatório da Comissão, anexo 3 do Relatório da IGIPSC, p. 54).

O professor Costa e Cunha, em 1872, ano em que estava regendo interinamente a cadeira de Santana, embora fosse favorável à coeducação dos sexos, questiona se a escola brasileira e o próprio povo tinham condições de lidar com ela. Ao alertar para os riscos que considerava existir, acabou por nos fornecer alguns aspectos do público atendido nas escolas públicas, confessando até mesmo a presença de escravizados, apesar de proibida por lei:

Nossa escola pública, como se sabe, está aberta para todos, graças às instituições sábias e livres que nos regem, e tanto tem ali entrada o menino das famílias livres como o das libertas e até das cativas; ora, seja qual for o estado ou a classe do homem livre, 
este não vê jamais com bons olhos seu filho em comum com o escravo de ontem, e, se assim é para o filho, que diremos da filha?

De sobejo sabemos que o menino, filho do próprio escravo, de bons costumes, é mais digno e estimável do que outra criança de melhor ou mais elevada condição, mas viciosa e perversa; assim pensamos nós outros, assim pensam os filósofos, os filantropos, mas o povo não é filósofo, nem filantropo, - eis aí tudo (Cunha. Coeducação dos sexos - Discurso relativo ao terceiro ponto, Conferências Pedagógicas, p. 3, Relatório da IGIPSC, 1872-2A).

Caso similar de alunos filhos de libertos e de escravizados foi localizado por Barros (2005) na Província de São Paulo no relatório de um professor que se queixava de "certos negrinhos que por ahi andão, filhos de Africanos Livres que matriculão-se mas não frequentam a escola com assiduidade, que não sendo interessados em instruir-se, só frequentariam a escola para deixar nella os vicios de que se achão contaminados" (p. 49). Segundo Barros, o professor não discordava que essas crianças fossem educadas. O problema estava em frequentarem a mesma escola onde estavam os "bons alunos". A diferença entre os dois casos residia na forma de abordar a questão por meio do critério de moralidade. Enquanto o professor de São Paulo era avesso à situação, o professor da Corte, apesar de concordar que era algo mal visto, asseverava que o filho do escravo de bons costumes poderia ser mais digno e estimável que a criança de condição mais elevada viciosa e perversa.

Tais relatos, juntamente com o fato da Escola Pública da freguesia de Santa Rita receber filhos ou tutelados de comerciantes, empregados públicos, militares, artistas, denotam a complexidade do público atendido pelo professor Pardal. O resultado da pesquisa nos periódicos também permite observar essa complexidade e os dados organizados em torno de pais e encarregados (apêndice 7) demonstram que exerciam um conjunto diverso de ocupações como sapateiro, cabeleireiro, caixeiro, militares, empregados públicos (amanuenses, contínuos, arruadores, praticantes), negociantes, artesãos, entre outros, e que participavam uma série de atividades que mostravam o envolvimento de tais sujeitos na vida econômica, social, cultural e política da cidade.

Luiz Rodrigues de Faria, pai de Carlos Rodrigues de Faria, de seis anos de idade em 1855, era amanuense da Mesa do Consulado da Corte, cujo primeiro registro localizado data de 1845 no Almanak Laemmert. Em 1857, passou a constar como escrivão do almoxarifado da Marinha. Nomeado capitão da segunda 
companhia da Guarda Nacional em 1841, foi dispensado do cargo em 1848. Fez parte do conselho de jurados da Corte em vários julgamentos. Em 1844, estava na lista de eleitores da freguesia de Santana. Em 1854, constava como secretário adjunto da Sociedade de Baile Sylphide e, em 1857, numa lista de irmãos e devotos que contribuíram com donativos para o traslado da imagem do Senhor do Bonfim para Irmandade Nosso Senhor do Bonfim (Correio Mercantil, 11 dez. 1857). Mudou de endereço muitas vezes, conforme mostram os registros do Almanak, e morreu em 1899 (Jornal do Brasil, 24 nov. 1899).

O percurso da vida do empregado público Luiz forneceu elementos para organizar a análise das atividades das famílias dos alunos. Luiz passou pelo funcionalismo público de baixo escalão, Guarda Nacional, júri da Corte, atuou no processo eleitoral e em sociedades. Com exceção da profissão, que não era compartilhada por todos, a vida desse pai ou encarregado consegue resumir os processos pelos quais estiveram envolvidos, em maior ou menor grau, vários dos sujeitos identificados em diferentes momentos de suas trajetórias de sobrevivência, ao mesmo tempo em que se cruzam com a trajetória do professor da escola de seus filhos e tutelados. Nesse sentido, apresento a seguir uma reflexão que começa por abordar diferentes ocupações dos pais e que depois que se agrupa em torno dos processos eleitorais, do aparato de repressão (Guarda Nacional, instituições militares, sistema policial, júri) e do envolvimento em sociedades, irmandades e demais instituições de sociabilidade.

\section{Entre negócios, artes e agências}

Em fragrante - Às 11 horas da noite de anteontem o preto Francisco, escravo de F. Batista, foi preso na ocasião em que galgava o telhado da casa n.181 da Rua da Gamboa, onde reside Theodoro Jansen Muller.

Diário do Rio de Janeiro (8/12/1875)

Theodoro Muller era pai de um aluno de mesmo nome. Não foi localizado nenhum registro de que tivesse escravos, mas, por viver em uma sociedade escravista, Theodoro, mesmo que fosse abolicionista, não poderia evitar passar por situações ligadas ao modo como funcionava a escravidão, da qual faziam parte a própria fuga e a prisão de escravizados que tiveram como cenário o telhado de sua residência. 
Não foi possível, por meio das notas de jornais, identificar a cor das personagens investigadas, embora seja conhecida a presença de libertos e até mesmo de cativos frequentando as escolas da Corte. Por outro lado, o comprometimento de pais e encarregados (e de ex-alunos) com o regime escravista é algo notável. Pelo menos onze tiveram escravos. $\mathrm{O}$ arremate de espólio foi um recurso que permitiu identificar vários casos.

Outras maneiras de identificação se deram por meio da venda de escravos (Matheus de Oliveira Borges, Diário do Rio de Janeiro, 11 jan. 1853); de anúncios de escravos fugidos (João Luis Pereira de Souza, Correio Mercantil, 03 mar. 1856); noticiário sobre acidentes, como o escravo remador que quase morreu afogado em um acidente com bote (escravo do mestre de embarcação Pedro José d'Azevedo, Diário do Rio de Janeiro, 04 out. 1864) e outro atropelado por um Tilbury (escravo do comendador Bernardo Gomes Braga, Correio Mercantil, 08 abr. 1860); anúncio de libertação de escravos (Manoel Ferreira dos Santos Lima, Mercantil, 19 abr. 1884); convocação de indivíduos intimados a entregarem seus escravos para serem alforriados pelo fundo de emancipação (Adriano José da Silva Braga, Gazeta da tarde, 11 fev. 1885); bem como lista de passageiros de embarcações.

O caso do mestre de embarcação Pedro José d'Azevedo chama atenção pelo fato dele ter sido responsável por uma viagem para Angola em 4/12/1839 (Diário do Rio de Janeiro, 05 dez. 1838). Pedro era encarregado do aluno Jacob José Lopes, filho de outro mestre de embarcação de mesmo nome. O pai Jacob consta, por exemplo, como mestre da embarcação vinda do Zaire em 05 de dezembro de 1839, um dia após a partida de Pedro para Angola (O Despertador, $06 \mathrm{dez}$. 1839). Tais informações sugerem que ambos poderiam estar envolvidos com o tráfico negreiro.

A centralização das análises no regime escravocrata, conforme apontam alguns pesquisadores, obliterou por muito tempo a investigação em torno dos trabalhadores pobres e livres no Império e suas estratégias de se inserir no mundo do trabalho (Dias, 1998; Badaró Mattos, 2004 e 2007; Carvalho Costa, 2012). No entanto, conforme assinala Badaró Mattos, "trabalhadores escravizados e livres conviviam lado a lado, nas ruas, moradias e locais de trabalho das maiores cidades brasileiras" (2007, p. 4). E ao compartilhar uma série de espaços, em tais circunstâncias, Badaró Mattos defende que não poderia ser considerado estranho que esses trabalhadores, fossem eles escravizados ou livres, "também compartilhassem valores, hábitos, vocabulário, experiências enfim, inclusive de 
organização e de luta, ainda que as diferenças entre sua condição jurídica criassem distâncias significativas" (2007, p. 4).

O pesquisador aponta, apoiado em dados de Eulália Lobo, que "em 1822 eram 30 os ramos artesanais e 233 os artesãos localizados na cidade, enquanto em 1852, contavam-se 46 ramos e 991 oficiais e artesãos" (p. 235). No final de 1850, houve uma diminuição dos artesãos decorrente do declínio da corporação, mas provavelmente em razão da absorção desses trabalhadores autônomos pelas fábricas, oficinas e pelo processo manufatureiro. Nas fábricas, era possível encontrar escravizados e livres, estrangeiros e nacionais, homens e mulheres, adultos e crianças, dividindo as tarefas de produção.

No caso dos pais e encarregados investigados, vários tiveram registros no Almanak Laemmert constando em ocupações como sapateiro, cabeleireiro, costureira, relojoeiro, carpinteiro, ferreiro, boticário, caixeiro, mestres de embarcação, negociantes e donos de armarinhos de fazenda/roupa, de armazéns de secos e molhados, armazém de materiais para obra, proprietário de pedreira. Ocupações que mais tarde também foram assumidas por filhos ou tutelados.

Em outros casos, com a morte dos responsáveis e o arremate do espólio para pagamento de dívidas ou com a falência dos negócios, os filhos tiveram que buscar alternativas para seu sustento. Também houve situações em que a busca por outra ocupação não teve relação com a falência do negócio. Foi o caso do arremate do espólio do português Antonio Ferraz de Macedo, dono de armarinho e de loja de fazenda e roupa, atividade geralmente associada aos imigrantes portugueses, da mesma forma que os armazéns de secos e molhados (Martinho, 1992). Antonio faleceu em 1871 e a massa falida foi arrematada no mesmo ano. No entanto, seu filho Francisco já estava cursando a Faculdade de Medicina, formando-se farmacêutico em 1867 e médico em 1873. Foi bem sucedido na carreira, tornando-se especialista em antropologia criminal (ver apêndice 7).

Nas famílias dos que se mantiveram na ocupação, podemos citar o pai de Manoel Nunes Pinheiro, José Nunes Pinheiro, que era sapateiro listado no Almanak Laemmert. Exercia sua atividade no mesmo endereço fornecido nos mapas de matrícula da escola de Santa Rita e sua produção era voltada para o público masculino. Não foram localizadas muitas informações sobre José, assim como de outros pais artesãos, mas, por outro lado, seu filho que também seguirá a carreira de "artista” aparece em várias notas de jornais em razão de sua intensa atuação nas associações de cunho operário, como será abordado mais adiante. Parece que ambos tiveram experiências distintas com suas ocupações, talvez 
motivadas pelas mudanças na dinâmica econômica, social e política do país que se desenrolou nas décadas seguintes e que propiciaram ao ex-aluno ter um outro tipo de engajamento na sociedade.

A única mulher cujo ofício pôde ser identificado foi Fortunata Maria de Mendonça. Ela aparece no Almanak Laemmert de 1856, na lista de modistas e costureiras. A identificação das mulheres nas notas de jornais é mais difícil em razão dos nomes que eram muito comuns, tornando complicado distinguir quem seria quem, mas isso não significa que as mulheres não exercessem atividades remuneradas, nem que as mulheres de famílias mais abastadas vivessem na passividade (Dias, 1995). Os nomes que compunham a lista de modistas e costureiras do Almanak Laemmert nos dão noção da quantidade expressiva de mulheres nessa ocupação somente na região central da cidade. A presença feminina também pode ser observada na administração de irmandades, da qual a costureira Fortunata também fez parte.

Dias (1995) chama a atenção para o conjunto de mulheres que assumiam negócios e respondiam por dívidas dos maridos após ficarem viúvas, bem como faziam requerimentos nos processos de herança, alegando possuírem capacidade financeira e administrativa de gerir bens e cuidar de empréstimos. Situação similar pode ser vista na Província de Minas Gerais, bem como mulheres chefiando domicílios e responsáveis pelo sustento da família (Gouvea, 2003). Desse modo, Gouvea (2003, p. 4), alerta que

[...] ao se analisar a posição da mulher na sociedade mineira oitocentista cabe dar destaque às complexas relaçóes entre os domínios público e privado, não entendendo a inserção feminina no espaço doméstico como expressão de uma vivência restrita aos cuidados com a casa e a educação dos filhos, mas a uma indiferenciação entre os serviços domésticos e as atividades remuneradas tidas como femininas, atividades que engendram uma relação com o domínio público da vida social.

No caso dos pais e encarregados homens que faleceram, foi possível identificar algumas esposas cuidando dos seus inventários como Anna Rosa de Jesus Leal, viúva de José Joaquim Ferreira Leal, proprietário de uma pedreira (Diário do Rio de Janeiro, 04 abr. 1864, 11 jun. 1864), e Maria Rita dos Santos Ferraz de Macedo, viúva do já mencionado português Antonio Ferraz de Macedo, que, mesmo sem saber escrever, dirigiu uma petição ao juiz de direito requerendo declarar falência dos negócios do falecido e convocando os credores para nome- 
ação. O documento foi redigido pelo filho, ex-aluno de Pardal, que assina "Por minha mãe, por não saber escrever” (Diário do Rio de Janeiro, 19 set. 1871). Se a viúva não estivesse à frente dos procedimentos necessários para cuidar da "massa falida" do falecido esposo, o filho não precisaria informar que escrevia por ela, pois ele mesmo poderia ter assumido a tarefa.

\section{Votantes, eleitores e partidários: a participação em processos eleitorais e ativi- dades correlatas}

Contínuo da alfândega, fundidor da Casa da Moeda, ajudante do Correio da Corte, amanuense da Secretaria de Estado dos Negócios do Império, empregado do Quartel General da Marinha, guarda da Alfândega. Estas são algumas das ocupações exercidas no "serviço público" pelos pais e encarregados dos alunos da Escola Pública de Santa Rita.

A existência de vários empregados públicos traz à tona a necessidade de discutir a categoria e um aspecto do funcionalismo público no século XIX que tem a ver a configuração do sistema eleitoral que ajuda a compor. Carvalho (2007) em sua conhecida obra $A$ construção da ordem, ao tratar da estratificação do funcionalismo público, alerta

O que não se mencionava no Império era o serviço público como fonte de emprego para a população pobre urbana, em parte talvez por não se considerarem empregados públicos os operários do Estado (os próprios serventes eram pagos com verba de material), em parte pela pequena agressividade desses grupos na época (p. 165).

Apesar de Carvalho mencionar a existência significativa deles, o autor parece não atribuir importância política aos cargos de baixo escalão na "construção da ordem”. No entanto, em pesquisa sobre votantes pobres no Império, Dias (1998), ao chamar a atenção para o fato de que a visão que consolidava a hegemonia política das elites no Império na historiografia impossibilitava "documentar a pluralidade, as diferenças, os regionalismos, as conjunturas que envolviam modos de sobrevivência de grupos sociais oprimidos" (p. 57), faz a crítica de que tal concepção 
[...] ocultou por completo a possibilidade do desvendar da experiência de grupos não determinantes nem hegemônicos e das vicissitudes pelas quais passaram no processo de sua nova inserção nas sociedades locais, regionais, para não nos remetermos de novo à própria hegemonia do poder que constituía o país, a nação, o governo (p. 59).

Em tais circunstâncias se inscreve a questão da inserção dos homens livres no eleitorado pobre, abrindo "espaços para estudo das tensões sociais ocasionadas pela sua resistência à política de dominação” (p. 61), perante a qual Dias defende a necessidade de relativizar certos conceitos como o de "clientela paternalista". Para ela, "a condição subalterna e subordinada dos homens livres na sociedade escravista é indiscutível, porém as relações de dependência no conjunto da população dos marginalizados era certamente mais fluida do que deixam entrever alguns autores" (p. 62).

Dessa forma, a mobilidade da população livre dentro no perímetro urbano - costume antes típico das zonas rurais, as chamadas "roças volantes" - é um sintoma desta questão que se transformava "em recursos de resistência à fixação, à dependência pessoal, ao trabalho permanente” (p. 62), ou seja, homens livres sem propriedade viviam em trânsito. O empregado público Luiz Rodrigues de Faria, por outro lado, tinha trabalho permanente, mas seu endereço se alterava com muita frequência. Não tinha residência fixa por muito tempo. Entre as muitas explicações possíveis, a falta de imóveis acessíveis financeiramente poderia ser considerada, mas talvez dependesse de favores pessoais ou investisse em um jogo de favores, mudando conforme fosse mais conveniente.

Visto como problema, essa prática conduz à questão da consolidação do sistema de controle social tornando-se "preocupação das autoridades locais, das juntas de qualificação [de votantes], dos juízes de fora e chefes de polícia em registrar mudanças de domicílio" (Dias, 1998, p. 63), o que funcionava também como um modo de estender as malhas do poder central. Nesse sentido,

É de particular interesse estudar o fenômeno de arregimentação dessa população pelas elites dominantes e a construção paulatina de recursos administrativos e de leis para cooptá-los à população do Império como cidadãos pobres, porém efetivamente integrados no sistema político, na medida em que formalmente podiam votar (Dias, 1998, p. 67-68). 
Para a autora, o patronato interferiu na arregimentação da população pobre por distribuir empregos públicos e criar laços de clientela pessoal, mas ele era contido pelo número menor de cargos públicos nas localidades e províncias, “assim meeiros, escrivães, pequenos funcionários, porteiros e guardas de registro não chegavam a ter a importância decisiva que tinham na Corte” (p. 70).

A ideia de que tais empregados tinham maior importância na Capital do Império nos atenta para a quantidade de sujeitos cooptados na população pobre para ocuparem cargos considerados menores da administração na Corte:

Em 1864, comentava Alexandre Ferreira Soares o número elevado de pequenos funcionários públicos empregados pelo governo no arsenal da marinha, no Ministério da Guerra, na alfândega, no consulado, na tipografia imperial. Eram o núcleo dos cooptados dentre a massa de desfavorecidos e, com o tempo, definiriam-se como uma classe urbana de intermediários entre os escravos, os libertos trabalhadores de construção, os carregadores, os artesãos mais ou menos qualificados e os operários das manufaturas locais que contratavam trabalhadores nacionais. O poder público arregimentava a população local, os libertos, os mestiços, em vez de recorrer, como fazia a maioria das indústrias, ao trabalho dos imigrantes estrangeiros (Dias, 1998, p. 70).

A inserção de tais sujeitos no processo eleitoral remete à Constituição de 1824 que instituiu as eleições primárias, indiretas, em que votantes, qualificados, escolhiam eleitores. Estes, por sua vez, nas eleições de segundo grau, votavam para o Senado, Câmara dos deputados e Assembleias Provinciais. No âmbito local, também eram eleitos os vereadores e os juízes de paz.

A Constituição de 1824 estabeleceu a idade mínima de 25 anos (21 para casados, militares, clérigos e bacharéis) e instituiu o critério de renda mínima anual de 100 mil réis por ano para ser votante e 200 mil para ser eleitor. A partir da reforma de 1846 , o cálculo passou a ser em prata, o que equivalia ao dobro desses valores. Não havia exigência de alfabetização, mas era necessário realizar a qualificação dos votantes que se dava previamente ao dia das eleições, por meio de uma junta formada em cada paróquia, presidida pelo juiz de paz.

[...] na eleição primária, da qual participavam votantes pobres, as juntas de qualificação sempre representaram o modo como os proprietários e chefes políticos eleitorais manipulavam o poder local, de modo que os costumes de violência eleitoral e de 
recrutamentos arbitrários, que já tinham raízes na sociedade colonial, persistiriam até que a crise da escravidão impôs a necessidade de novos recursos para atrair o trabalhador livre (Dias, 1998, p. 71).

Alguns sujeitos investigados neste estudo compuseram as juntas, participando ativamente da qualificação dos votantes, ou seja, avaliando o direito de votar dos que poderiam ser considerados cidadãos. No mesmo conjunto de pessoas ligadas à escola havia, portanto, aquelas que podiam ser votantes, aquelas que avaliavam quem podia votar, os que não votavam e os que podiam ser eleitores, cujos filhos e tutelados compartilhavam a mesma sala de aula de primeiras letras.

Entretanto, Dias lembra que, em 1881, a lei Saraiva extinguiu as eleições primárias de votantes pobres e proibiu o voto do analfabeto. Carvalho (2007) destaca que o índice de participação nas eleições caiu drasticamente, somente sendo recuperado em 1945. Mas, até 1881, quando houve uma série de mudanças, muitos pais e encarregados do ano de 1855 estiveram envolvidos com o processo eleitoral na Corte, assim como o professor Pardal que era eleitor, constava nas chapas para voto dos votantes, votava nas eleições de segundo grau, participava das mesas de qualificação e esteve envolvido em episódio de violência na disputa entre partidos durante as eleições em 1868, como veremos adiante.

Entre aqueles que foram localizados apenas nas listas de qualificação de votantes estão o já mencionado Luiz Rodrigues de Faria; José Florencio de Lemos, 58 anos, empregado público (Diário do Rio de Janeiro, 25 jul. 1876); Theodoro Jansen Muller, 57 anos, empregado público, (Diário do Rio de Janeiro, 15 jul. 1876); Manoel José da Rocha Paranhos, 66 anos, empregado público (Diário do Rio de Janeiro, 05 fev. 1877); e Diogo Manoel Gaspar, 63 anos, proprietário (Diário do Rio de Janeiro, 05 fev. 1877). No caso de ex-alunos, o número é bem maior, 21 votantes, dentre os quais apenas cinco eram empregados públicos.

No entanto, também havia pais que pareciam estar no mesmo patamar político que Pardal, compondo chapa de eleitores, ainda que por partidos diferentes, e fazendo parte das mesas de qualificação, como Domingos Thimoteo de Carvalho, Francisco Joaquim de Nazareth, Joaquim José Pereira de Almeida e Francisco Xavier da Silva Moura. Outros estavam bem acima, eram políticos estabelecidos, como o conselheiro Manoel de Campos Melo e o Visconde de Baependy que haviam exercido, entre outros postos, a presidência de províncias.

Domingos Thimoteo de Carvalho ocupou mais de um cargo público na Câmara Municipal: foi nomeado "fiel das obras" em 1853 (Correio Mercantil, 
03 nov. 1853), depois escriturário da Diretoria das obras municipais (Boletim da Câmara, 1863, p. 15), oficial (Almanak Popular do Rio de Janeiro, 1878) e escriturário da repartição de aferição ( $O$ Cruzeiro, 02 nov. 1878). Também fazia parte dos quadros de repressão. Foi tenente da Guarda Nacional, inspetor de quarteirão da freguesia de Santa Rita (AL, 1854), juiz de paz da mesma freguesia (Gazeta de Notícias, 03 mar. 1878) e membro do júri da corte (O Cruzeiro, 02 ago. 1878). No âmbito social, foi secretário da mesa de fundação da Irmandade Santa Rita de Cássia (Gazeta de Notícias, 24 maio 1878).

Domingos aparece ao lado do professor Pardal em 1852, como suplente dos eleitores da freguesia de Santa Rita, convocados para instalação da mesa eleitoral para escolha de vereadores da Câmara Municipal e de juízes de paz (Correio Mercantil, 11 ago. 1852). Em 1855, foi secretário da junta de qualificação da freguesia de Santa Rita (Diário do Rio de Janeiro, 25 jan. 1855; A Actualidade, 23 jan. 1872). Em 1871, esteve como suplente de secretário, cujo titular era Francisco Xavier da Silva Moura, pai de outro aluno da turma de 1855. Francisco nas eleições de 1872 se tornou presidente da mesa paroquial - da qual Domingos foi secretário -, mas foi denunciado por ser morador da Rua de Todos os Santos que ficava na freguesia de Inhaúma, o que, portanto, o impediria de estar na presidência da mesa de Santa Rita (A Reforma, 12 set. 1872).

Domingos ainda exerceu outras atividades eleitorais como a de "escrutador" da mesa qualificação (Diário do Rio de Janeiro, 09 set. 1856; A Actualidade, 18 jan. 1864) e presidente da mesa qualificação de votantes da freguesia de Santa Rita (A Actualidade, 19 jan. 1874). Em 1863, tentou impedir uma infração à lei durante a contagem das cédulas da eleição (Constitucional, 12 ago. 1863). Cabe ressaltar que tais cargos foram ocupados por ele mais de uma vez, o que evidencia que o envolvimento de Domingos nos processos eleitorais teve uma significativa duração.

Domingos e Pardal estiveram juntos quando disputavam as eleições pela freguesia de Santa Rita, mas a partir de 1856, Pardal passa a aparecer como candidato pela freguesia de Santana, onde também encontraria, como adversários políticos sujeitos com os quais teve conexão a partir da escola. Depois passou a disputar pela freguesia do Engenho Novo, para onde se mudou após se aposentar.

No entanto, a primeira nota de jornal localizada durante a pesquisa com o nome de Pardal nos processos eleitorais data de 24 de dezembro de 1850 (Correio Mercantil) em que ele já aparece nas listas de eleitores, como suplente, o que demonstra que sua atuação nos processos eleitorais é mais antiga. Nos anos que 
se seguiram, o professor ora aparecia como eleitor, ora como suplente, ou como membro das mesas eleitorais (escrutador e mesário). Algumas notas referem-se a ele como eleitor pelo Partido Conservador, mas nas suas primeiras aparições localizadas nos jogos eleitorais, como a do ano de 1856, Pardal constava na lista de Zacharias de Góes e Vasconcellos, político liberal, o que demonstra o complexo jogo partidário da época. O resultado da votação elegeu Pardal juntamente com Zacharias, Francisco Joaquim de Nazareth, Visconde de Itaboraí (que tinha sido inspetor da instrução da Corte até o ano anterior, 1855, quando assumiu o cargo Eusébio de Queiroz), e Porfírio José da Rocha, médico e juiz de paz, com o qual se indispôs Francisco Nazareth no ano seguinte. Indisposições e misturas que podem ser compreendidas no âmbito da política de conciliação iniciada em 1853, abarcando os partidos Liberal e Conservador. Pardal aparecia novamente na chapa de Zacharias em 1860, em uma lista publicada - supostamente como provocação - pelo jornal Correio Mercantil e intitulada "Chapa Policial de Santana” (22 dez. 1860), talvez pela quantidade de pessoas que ocupavam cargos do aparato de repressão do Estado.

No âmbito partidário, cabe destacar que, até 1864, havia dois partidos, o Conservador e o Liberal, quando então surgiu o Partido Progressista, que se dissolveu em 1868. Parte dos progressistas formou o Partido Republicano, em 1870. Segundo Carvalho (2007), resumidamente, o Partido Conservador era composto pela "aliança da burocracia com o grande comércio e a lavoura de exportação; o Partido Liberal era a aliança dos profissionais liberais urbanos com a agricultura de mercado interno e de áreas mais recentes de colonização" (p. 408). O Partido Liberal tinha como principal demanda maior descentralização do Estado. Na década de 1860, novas reivindicações concernentes às liberdades civis, participação política e reforma social passaram a fazer parte da sua pauta. O Partido Conservador primava pela centralização política, fortalecimento do poder moderador, controle da magistratura e da polícia. Em sua curta vida, o Partido Progressista foi influenciado pelo conservador dissidente Nabuco de Araújo que almejava reformar os processos judiciários, separar as funções judiciais e policiais, além da demanda de maior descentralização. Em 1868, seu programa continha a abolição do Conselho de Estado, da Guarda Nacional, da vitaliciedade do senado, da escravidão e pedia a eleição direta e universal. O Partido Republicano reivindicava o federalismo, "verdade democrática”, representação, direitos e liberdades individuais (Carvalho, 2007).

Essa breve descrição dos partidos se faz necessária para compreender a dinâmica da participação dos sujeitos investigados nas eleições na Corte e as 
tensões, conflitos e violências que faziam parte do processo eleitoral, bem como dá a ver as intricadas relações existentes entre sujeitos que tinham conexões com a Escola Pública de Santa Rita e seu professor. No final da década de 1860 e início da de 1870, quando Pardal estava vinculado ao Partido Conservador, o tio homônimo de Antonio Joaquim Ferreira Leal foi eleito juiz de paz pelo Partido Liberal na freguesia de Santana (Correio Mercantil, 20 set. 1868) e, como "proprietário", constava na lista do Partido Liberal que garantia ser de "liberais distintos" (A Reforma, 18 ago. 1872). Pardal parecia ter uma relação mais íntima com a família Ferreira Leal, mas isto não impediu que nessa relação alguns pudessem estar em lados opostos nas eleições, nem que estivessem juntos na mesma nota de jornal para convidarem amigos e parentes para missa de sétimo dia de José Joaquim Ferreira Leal, pai do aluno Antonio Joaquim e irmão de um adversário político de Pardal.

Entre pais e encarregados eleitores, havia os que constavam na lista de eleitores governistas (Francisco Xavier da Silva Moura na freguesia de Santa Rita, Diário do Rio de Janeiro, 15 dez. 1860); na lista de eleitores do Partido Liberal (Manoel de Campos Mello, Correio Mercantil de 04 ago. 1849, Joaquim José Pereira d'Almeida, Diário do Rio de Janeiro de 01 nov. 1856 e Francisco Joaquim de Nazareth, os três na freguesia de Santana, Correio Mercantil de 02 ago. 1849); e na chapa do Partido Progressista (Joaquim José Pereira d'Almeida, Diário do Rio de Janeiro, 05 ago. 1863).

A polêmica na qual esteve envolvido Francisco Joaquim de Nazareth o motivou a publicar uma nota no Correio Mercantil (11 fev. 1855). Francisco questionava a postura do presidente da junta eleitoral, Porfírio José da Rocha, por não ter aceitado a lista do $2^{\circ}$ distrito de Santana, enviada por seu respectivo juiz de paz. O presidente considerava que tal procedimento não era da competência desse juiz, pois julgava que isto deveria ter sido feito pelo juiz anterior. No final, Porfírio decidiu aceitar a lista, mas a confusão parece ter custado o emprego de Francisco. Coincidentemente, em 1857, Francisco foi suspenso do cargo de escrivão do juizado da freguesia de Santana pelo juiz de paz Porfírio José da Rocha (Correio Mercantil, 09 jan. 1857).

Anos depois, em outra situação que sugere que havia sido reintegrado ao cargo, uma nota denuncia que a demissão do escrivão do juizado de paz da freguesia de Santana, Francisco Nazareth, seria uma "injusta e acintosa vingança" (Diário do Rio de Janeiro, 19 fev. 1861). Apesar de nesse momento o juiz de paz ser outro, a nota anônima alega que questóes políticas estavam envolvidas 
na demissão, em especial membros do Partido Conservador: "Continuem os homens da ordem em seu caminho desonesto; satisfaçam seus rancores; tudo lhes é lícito fazer, contanto que seus caprichos triunfem, já que perderam a eleição”. Entretanto, a carreira profissional e política de Francisco não pôde continuar por muito tempo em razão da sua morte, ocorrida pouco mais de um ano após a demissão (Diário do Rio de Janeiro, 11 maio 1862).

Segundo Graham (1995) as eleições mobilizavam o interesse da maioria da população masculina e o resultado "era que as eleições podiam ser eventos populares onde os líderes locais reafirmavam sua preeminência ante uma ampla audiência” (p. 359, tradução nossa). ${ }^{3}$ Pardal poderia ser considerado um líder local? Graham também assinala que, apesar dos candidatos a deputados receberem votos apenas dos eleitores, faziam isso por meio de cartas dirigidas aos mesmos e também aos "membros notáveis do povo, cada patrão local demonstrava sua importância induzindo aos votantes, seus clientes, a participar em tumultuosas manifestações” (p. 359, tradução nossa). ${ }^{4} \mathrm{O}$ resultado disso poderia terminar em alegria generalizada ou em confrontos armados.

Um artigo veiculado pelo Diário do Povo (24 set. 1868) nos relata um pouco dessa situação ao criticar o modo violento como os "eleitores conservadores", tendo como exemplo os da freguesia de Santana - a maioria empregados públicos, entre os quais constava Pardal -, agiram no dia da eleição, coagindo em favor de seus candidatos para eleição de deputado. A vertente política do jornal pode explicar o tom áspero do artigo de acusação aos eleitores que

[...] coadjuvados pelo inspetor geral de obras públicas bacharel Bulhões e seu caudatário Molina de Távora, que ostensivamente faziam pressão na porta da igreja sobre os empregados de sua repartição; sendo aliás todos eles empregados públicos, mais ou menos dependentes do governo.

Não foram somente sobre os empregados públicos, a coação também caiu sobre "votantes operários e guardas nacionais". O relato vai ao encontro da reflexão de Dias sobre a participação de votantes pobres e empregados públicos de baixo escalão que tinham um papel importante nas disputas eleitorais, o que

3 No original: "era que las elecciones podían ser eventos populares donde los líderes locales reafirmaban su preeminência ante uma amplia audiência”.

4 No original: "miembros notables del pueblo, cada patrón local demostraba su importancia induciendo a los votantes, sus clientes, a participar en tumultuosas manifestaciones". 
pode ser confirmado pela quantidade de sujeitos mobilizados e pelo tamanho da violência empregada para obrigar os indivíduos a votarem nas suas chapas.

Os chefes do partido conservador João e Antonio Mello, Castellões e Figanière, montados nesses notáveis caudatários, e auxiliados pelos majores Campos, comandante de urbanos, e Veiga, comandante do batalhão de Santana, postaram-se ao lado da urna e forçavam os votantes operários e guardas nacionais a lançarem nela as listas que por eles ali mesmo lhes eram dadas.

"Montados nos caudatários", referindo-se aos dois subdelegados de polícia e dez inspetores de quarteirão listados nominalmente, entre outros não citados, nomeados pela "política decaída”, juntamente com outros seis inspetores que "andavam publicamente dentro da igreja com os chapéus cheios de chapas, impondo e ameaçando por ordem e nome do governo", o artigo recrimina o que chamou de "bacanal eleitoral" promovido pelos eleitores e seus auxiliares que desceram até a mais "abjeta corrupção”.

Se partido fosse forte como se diz e se julga, para obter um triunfo legítimo, não precisaria descer até onde chegou; não se auxiliaria de facínoras, capoeiras, réus de polícia, urbanos e guardas disfarçados; não daria o triste espetáculo que horrorizou a todos os habitantes da Corte [...].

O Diário do Povo termina afirmando que o triunfo não foi do Partido Conservador, mas da "fraude de aventureiros ignóbeis que queriam aparentar prestígio e influencia”. Apesar da violência ocorrida, os liberais comemoraram a vitória nas eleições, o que demonstra que, mesmo com agressões, havia resistência por parte dos eleitores coagidos. O que chama bastante atenção ao longo do artigo consiste no levantamento nominal dos sujeitos do aparato de repressão mobilizados para a força-tarefa empreendida pelo Partido Conservador, procedimento possível em razão de suas posições na máquina do governo:

Dispondo de todos os recursos que suas posições oficiais lhes traziam; auxiliados pela polícia de então, que por uma das maravilhas comuns do atual reinado era quase a sua totalidade a mesma de hoje, tentaram derrotar os liberais que resistiram e triunfaram $[\ldots]$. 
Tal acontecimento ilustra o fato de que os processos eleitorais tinham íntima relação com o aparato policial e repressor, bem como com a Igreja, local onde eram realizados os escrutínios. Era no seu interior, portanto, que aconteciam os atos de intimidações, violência e conflitos, durante a eleição que, ironicamente, tinha o trabalho iniciado após uma missa rezada pelo pároco responsável.

\section{Pais e encarregados no aparato de repressão: Guarda Nacional, instituiçôes militares, polícia e o júri da Corte}

"Portando duas pistolas e um sabre, um apito para chamar reforço preso à jaqueta azul do uniforme firmemente abotoada e chapéu azul alto, sobressaindo à distância, os soldados militares patrulhavam as ruas em pequenas unidades" (Holloway, 1997, p. 165). A descrição da indumentária ajuda apreender as maneiras de se tentar homogeneizar a postura dos sujeitos da polícia militar em serviço, mas quanto à situação social, segundo Holloway, o que se observa é que se tratava de homens de diversas origens. Nesse sentido, insere-se o alistamento de escravizados que se passavam por libertos e que

[...] sugere a existência de considerável diversidade étnica e racial nas fileiras da Polícia Militar, que aceitava indiscriminadamente negros e mulatos, juntamente com os de origem europeia, inclusive muitos portugueses de nascimento. [...] $\mathrm{O}$ que os soldados de polícia tinham em comum, além de saúde razoavelmente boa e condição livre, era a origem na extremidade inferior da pirâmide social - a mesma categoria social que era o alvo principal da ação policial (p. 163).

Alguns sujeitos pesquisados tinham ligações tanto com os processos eleitorais quanto com o aparato de repressão. Ligações que também se davam no âmbito da governança. Segundo Dias (1998), a partir de 1846, as juntas de qualificação de votantes passaram a controlar também o recrutamento: "os vadios, os pobres, os desocupados, os que não tinham sequer condições de ser votantes, eram recrutados para o exército de linha” (p. 68). Recrutamento que fazia parte do protocolo de uma série de instituições.

Os anos situados entre 1833 e 1841 foram considerados por Holloway (1997) um período de transição no aparato de repressão no Rio de Janeiro. Para o autor, em 1833, as três vertentes formadas com a instalação da Secretaria de Polícia - a Guarda Nacional, a Polícia Militar e as primeiras instâncias judiciais 
(juízes de paz, seus inspetores de quarteirão e chefes de polícia) - partilhavam funções e tinham limites imprecisos de autoridade, gerando tensões e disputas entre os grupos de repressão.

A Polícia, criada em 1831 para substituir a Guarda Real de Polícia, tinha muitos problemas para preencher suas fileiras, mas sua força tinha grande valor para o governo. No ano de 1833, sua "principal tarefa política, pelo menos na capital do Império, era garantir que as eleições para vereadores da cidade, juízes de paz e membros do Colégio Eleitoral correspondessem de maneira favorável aos interesses da facção no poder" (Holloway, 1997, p. 152). Apesar do uso "partidário",

As rivalidades políticas atingiam um ponto crítico nas eleições para a Câmara Municipal da cidade e os cargos de juízes de paz, quando então patrulhas da Polícia Militar montavam guarda para impedir que grupos de partidários, muitas vezes armados de porretes, ferissem os eleitores que se opunham a "seus sentimentos" (p. 154, aspas do autor).

Segundo o autor, a reforma de 1841 alterou a estrutura institucional do sistema de policiamento da cidade e despojou de autoridade política os juízes de paz, que não poderiam mais acusar nem sentenciar. Seu sucessor funcional em termos de autoridade e território foi o subdelegado de distrito. Cada província teria um chefe de polícia. No Rio de Janeiro, ele era nomeado pelo Imperador e prestava contas ao Ministro da Justiça, indicando os delegados e subdelegados, a serem nomeados também pelo Imperador, e estes últimos indicavam os inspetores de quarteirão para serem submetidos à aprovação do chefe de polícia.

Pela reforma de 1841, os chefes de polícia, delegados e subdelegados tinham plena autoridade, no âmbito das violações das posturas municipais e de todas as contravenções, para expedir mandados de busca e apreensão, efetuar prisões, incriminar formalmente, determinar fiança, conduzir audiências judiciais sumárias, pronunciar sentença e supervisionar a punição - tudo isso sem a intervenção de qualquer outra autoridade (Holloway, 1997, p. 158).

Os subdelegados eram distribuídos pelos distritos e podiam nomear "oficiais de justiças" para assisti-los ou para agradar amigos com um cargo que não era remunerado, mas que dispensava do serviço na Guarda Nacional. Entretanto, a 
menor divisão administrativa era o quarteirão, do qual um morador era nomeado “inspetor de quarteirão", também não remunerado e subordinado aos subdelegados, cujo papel era "ficar alerta às atividades suspeitas, maléficas ou ilegais em sua jurisdição local, efetuar prisões em flagrante e atender ao pedido de ajuda de outras autoridades, quando necessário" (p. 161).

Francisco Xavier da Silva Moura, várias vezes mencionado neste estudo, foi suplente do subdelegado da freguesia de Santa Rita (1874), assim como o professor Pardal, suplente do subdelegado do $2^{\circ}$ distrito da freguesia de Santana (Diário do Rio de Janeiro, 24 set. 1861). No ano seguinte, Pardal assumiu a condição de subdelegado e publicou nota sobre dia e horário de atendimento do posto, e o local, sua residência na Rua da Imperatriz, n. ${ }^{\circ} 125$, ou seja, o mesmo endereço da escola (Correio Mercantil, 16 set. 1862).

À condição singular do professor Pardal nesse momento se atribui grande poder simbólico. A combinação entre escola, subdelegacia de polícia e residência aproxima ainda mais os vínculos existentes na convenção estipulada entre os sujeitos que educam e os que devem ser educados, os que vigiam e os que devem ser vigiados, os que punem e os que devem ser punidos. Cabe lembrar que os sujeitos do aparato da instrução pública podiam recorrer àqueles do aparato policial para fiscalizar e obrigar aos pais e tutores a enviarem seus filhos para a escola. Mas, e se os aparatos coexistissem no mesmo espaço? Nesse caso, o professor Pardal encarnava na mesma pessoa, sem sair de casa, as funções de ensinar, vigiar e punir, constituindo de tal forma uma primorosa tríade de ações que iam perfeitamente ao encontro dos esquemas da governabilidade engendrados pelo Estado Imperial.

Para realizar tal tarefa, o professor contava com o auxílio dos inspetores de quarteirão. Das listas dos mapas de matrículas de 1855, nenhum pai ou encarregado esteve sob a chefia de Pardal na função de subdelegado de Santana, mas cabe destacar a presença de um colega, também professor público primário ocupando, a função de inspetor de quarteirão na freguesia nesse período, Antônio Estevão da Costa e Cunha. Colegas de profissão, mas com outra condição hierárquica no aparato policial da cidade.

No entanto, foi possível encontrar pais e encarregados nomeados para a função de inspetor de quarteirão na freguesia de Santa Rita: Francisco Xavier da Silva Moura (1850), Domingos Thimoteo de Carvalho (1854) - ambos, como pode ser visto no levantamento da pesquisa, exerceram juntos mais de uma atividade - e Manoel Antonio Mafra (1862). 
Entre outras forças de apoio à polícia estavam "vigias de parques, fiscais do comércio e guardas de edifícios públicos e outras instalações, cuja autoridade era muito restrita. Os guardas municipais não estavam integrados na hierarquia da polícia, embora pudessem ser considerados auxiliares" (Holloway, p. 165). Fizeram parte de tais cargos Domingos Monteiro da Silva, primeiro como guarda da Alfândega (Diário do Rio de Janeiro, 18 abr. 1846) e depois guarda vigia da freguesia de Santana (Boletim da Ilustrissima Câmara Municipal, 1862, p. 15; Correio Mercantil, 14 maio 1863); João José Rebello, guarda de segunda classe da Alfândega da Corte (Correio Mercantil, 05 fev. 1858); João Luis da Costa Oliveira consta como guarda da Alfândega de primeira classe em 1858 (Correio Mercantil, 05 fev. 1858), mas há uma nota de jornal de 1851 sobre uma apreensão de dez carneiros na Praia do Peixe feita por ele, enquanto guarda da Alfândega (Diário do Rio de Janeiro, 05 set. 1851).

O responsável pelo aluno Luís Antunes Ferreira, João José Alves Ferreira, foi fiscal de várias freguesias. A primeira identificada foi a de São José, na qual tinha como suplente o professor público primário da escola da freguesia de Sacramento Polycarpo José Dias da Cruz (Diário do Rio de Janeiro, 08 mar. 1855). Depois aparece como fiscal da freguesia de Santana (O Correio da Tarde, 16 fev. 1857), assinando vários anúncios nos jornais a respeito das normas estabelecidas pela Câmara em vários quesitos, bem como anúncios de arremates, como o do "cavalo russo pombo pintado" apreendido no Campo do Senado (O Correio da Tarde, 19 nov. 1857) e a norma de proibição do entrudo em fevereiro de 1857 . Nessa última nota, informa as multas aos infratores, a punição de prisão para os escravos e a ameaça de inutilização das "laranjas de entrudo" que eram feitas de cera com perfume, nem sempre agradável, lançadas em "guerras" e comumente atiradas nos transeuntes ( $O$ Correio da Tarde, 17 fev. 1857). No caso desse festejo, João José estava do lado de quem deveria proibir o evento, mas, como veremos no próximo item, ele também esteve do lado de quem organizava e anunciava festas populares.

Em 1858, João José foi nomeado fiscal de Sacramento, cuja posse foi anunciada em nota assinada por "Os justos do Sacramento", direcionada ao vereador da freguesia. A nota o agradecia por nomear um fiscal que "tantos serviços prestou na freguesia de Santana" e assim não consentir que o antigo fiscal, "barra de chumbo revestida de autoridade", "percorresse as ruas armado de bengalão insultando, provocando, desrespeitando tudo como um possesso, sem rédeas, sem governo, sem temor!" (Correio Mercantil, 27 maio 1858). João José parece ter construído uma boa fama ou reunido bons contatos, a contar pela 
nota e pela apresentação concedida por João Caetano dos Santos, no Teatro de S. Pedro de Alcântara, em benefício da viúva e dos filhos, após sua morte (Correio Mercantil, 22 fev. 1859). Uma ação de caridade que certamente fracassaria caso houvesse antipatia da parte do público, como no caso do antigo fiscal execrado pelos moradores de Sacramento.

Outra força auxiliar da polícia era a Guarda Nacional, criada em 1831 para substituir as milícias paramilitares, com o dever de defender a Constituição, a integridade da Nação e ajudar o Exército na defesa das fronteiras do país (Holloway, 1997). O serviço não era remunerado e as dispensas eram decididas por juntas presididas pelos juízes de paz, o que dava aos ricos e poderosos, seus filhos e protegidos grandes chances de serem dispensados. Dessa forma, emergia uma incongruência, pois o "serviço na guarda visava a estender a responsabilidade pela defesa da propriedade e da ordem social aos membros da sociedade que tinham interesse em manter o status quo" (p. 89), mas, na prática, essas pessoas evitavam o serviço e com isso

No Rio, esse ônus recaiu de forma desproporcional sobre pequenos comerciantes, artesãos, empregados de escritório e demais membros da pequena burguesia, que eram economicamente privilegiados no contexto relativo da sociedade, mas não tinham influência, diretamente ou por meio de algum pistolão, para obter a dispensa (p. 89).

A nomeação também atingiu os sujeitos da escola de Santa Rita. No conjunto estudado, havia capitão, tenente, sargento e alferes. Entre os pais e encarregados, Luiz Rodrigues da Silva foi capitão da segunda companhia da Guarda Nacional da Corte (Diário do Rio de Janeiro, 06 out. 1841); Alexandre Soares Pinheiro, relojoeiro, tenente da Guarda Nacional (Diário do Rio de Janeiro, 14 jun. 1839); Domingos Thimoteo de Carvalho, tenente secretário do conselho de qualificação da Guarda Nacional da Ilha do Governador (Diário do Rio de Janeiro, 20 mar. 1851); Francisco José Ferreira Villaça, $1 .^{\circ}$ sargento do 4. ${ }^{\circ}$ batalhão da Guarda Nacional (Diário do Rio de Janeiro, 16 nov. 1844) e pede para ser nomeado alferes da Guarda Nacional da Corte (Diário do Rio de Janeiro, 15 nov. 1847); Joaquim José Pereira d'Almeida, alferes do corpo de cavalaria da Guarda Nacional (Diário do Rio de Janeiro, 05 dez. 1839); Visconde de Baependy, 
tenente-coronel da Guarda Nacional (1832); ${ }^{5}$ Comendador Bernardo Gomes Braga, capitão da Guarda Nacional (AL, 1857).

Importa considerar, também, a instância responsável por julgar aqueles que eram acusados ou presos pelos agentes de repressão e que poderiam ser levados ao Júri da Corte. O conselho de jurados fazia parte da organização judiciária instituída pelo Código do Processo Criminal de 29 de Novembro de 1832 e reformada em 1841 (Flory, 1986).

Eram julgados aptos para serem jurados os que pudessem ser eleitores, soubessem ler e escrever, tivessem rendimento anual de quatrocentos mil reis, ou emprego público, ou o dobro do valor quando o rendimento proviesse do comércio ou indústria. As listas de jurados eram organizadas pelos delegados de polícia e enviadas ao juiz de direito que com o promotor público e o presidente da Câmara Municipal formavam uma junta de revisão para compor uma lista geral dos jurados, excluindo os indivíduos conceituados por não terem bom senso, integridade e bons costumes, e os condenados por determinados crimes (Flory, 1986).

Flory (1986) aponta que, no Código de 1832, o sistema de jurado, marca do liberalismo, foi considerado um princípio de participação popular aplicado ao judiciário e visto como um ataque à elite judicial. Com a reforma de 1841, os reformadores conservadores procuraram assegurar que a maioria dos jurados estivessem dominados por proprietários de terra e por servidores públicos, em razão dos laços de dependência com o governo, o que se refletia na seleção dos jurados, que se dava em todos os níveis por pessoas nomeadas pelo governo.

Alguns pais e encarregados responsáveis por vigiar e com atribuição de efetuar prisões, como juiz de paz, inspetores de quarteirão, vigias e membros da Guarda Nacional, também fizeram parte do júri da Corte - como o já mencionado Domingos Thimoteo de Carvalho, que ao longo de anos foi eleitor, membro de juntas de qualificação, escrutador de mesa eleitoral, tenente da Guarda Nacional, juiz de paz, inspetor de quarteirão, fiscal e oficial da Câmara Municipal. Domingos estava comprometido com vários níveis do governo da população, das eleições ao aparato policial, passando pelo julgamento no sistema judiciário. Reflexão similar pode ser atribuída ao professor Pardal que também participava dos conselhos de jurados. Desse modo, pode-se acrescentar mais um verbo às atuações de Pardal na sociedade: ensinar, vigiar, punir e julgar.

5 Site da Câmara dos Deputados, Presidentes da Câmara dos Deputados, disponível em http://www2.camara.leg.br/a-camara/conheca/historia/presidentes/braz_gamal.html. Acesso em 14 fev. 2020. 
Entre os pais, foi possível identificar um que passou pelo júri não como jurado, mas como réu. O caso do carpinteiro Leopoldino das Chagas Oliveira, pai de Perciliano das Chagas Oliveira, que na época tinha nove anos, recebeu um longo relato no jornal Correio Mercantil (24 set. 1857), na sessão chamada "Crônica Judiciária”. O relato começa em tom jocoso:

Acabei de tratar do processo de um carpinteiro, e vou ocupar-me do de outro carpinteiro, e, coincidência notável, ambos acusados do mesmo crime!

A história que vou contar agora é muito curiosa, e se deu água pela barba ao acusado Leopoldino das Chagas e Oliveira, vai pôr meia dúzia por aí às carreiras. Aqui realiza-se a verdade do adágio - vira-se o feitiço contra o feiticeiro (grifos no original).

O autor do texto relata que Joaquim Proença contratou Leopoldino para fazer uma obra por $600 \$ 000$ e solicitou também algumas madeiras no valor de $250 \$ 000$. Proença conseguiu de Leopoldino um recibo para apresentar ao seu padrinho e obter a quantia, já que não a possuía naquele momento. Leopoldino encomendou as madeiras a uma terceira pessoa, Manoel Joaquim Nogueira. Uma vez que não havia recebido o dinheiro de Proença, avisou a Manoel para não entregar a encomenda mesmo que apresentasse o tal recibo que ele havia passado de boa fé. Proença foi buscar as madeiras, mas Manoel já prevenido não as entregou. No mesmo dia, Proença foi à delegacia dar queixa contra Leopoldino por crime de estelionato. Feito o processo, foi emitido o mandado de prisão de Leopoldino que, ao ser abordado por "filantes" de Proença, implorou para não ser mandado para "correção" e acordou o pagamento de 1:000\$ para ser "deixado em paz”. Ele se dirigiu, então, à botica do irmão no Engenho Velho, com o qual não conseguiu a quantia, e depois encontrou um amigo que o forneceu $900 \$$. De posse do valor, Proença se reuniu na casa de José Thomaz de Aquino, onde fez um "contrato" em que registra que "conchavado, contratado e convencionado" com Leopoldino, desistia da queixa contra o carpinteiro por este ter vendido a ele madeira que não tinha sido paga, "salvando deste modo de uma prisão na casa de detenção a um brasileiro pai de família”.

Pelo relato, podemos ver o sufoco pelo qual passou o carpinteiro diante de um empregador que agia de má fé, contra o qual parecia estar impotente ou em desigualdade de condições para requerer justiça. Nesse caso, a solução encontrada foi pagar para não ser denunciado por um crime que não cometeu, contando 
com a ajuda de laços de solidariedade e, com isso, evitar um prejuízo maior, ser condenado, preso e impossibilitado de ganhar o sustento de sua família.

O relator descreve que Leopoldino "supôs-se escapo; mas a justiça que não faz contratos, fez-lh'o passar pelo desgosto que ele com razão procurou evitar. Levou-o a correção, e dali ao júri”. Ele então transcreve resumidamente o que ocorreu na sessão. O promotor destruiu a alegação de Leopoldino de que teria passado o recibo de boa fé, "para o que convinha considerá-lo muito simplório, senão estúpido”. Mas, Dr. Russell -provavelmente um advogado - examinou peça por peça dos autos e "deixou a toda luz a inocência de Leopoldino e a imoralidade que ressumbra do processo, que pasmou a todos”. O juiz de direito, de acordo com o voto unânime do conselho de jurados, absolveu o carpinteiro.

Apesar dos prejuízos que teve por ter sido preso, o final terminou a favor de Leopoldino, graças à astúcia do Dr. Russell e a decisão do júri. Chama atenção o empenho em inocentar um trabalhador que não tinha recursos nem para pagar o "suborno". A crônica traz a lista dos jurados que compunham o conselho que absolveu Leopoldino. Na lista não havia nenhum dos personagens investigados na pesquisa, embora também pudesse ser composto por outros trabalhadores, ou empregados públicos de baixo escalão, possivelmente mais sensibilizados com o problema, como os vários outros pais que fizeram parte do conselho de jurados: o fiscal de freguesia João José Alves Ferreira, o guarda da alfândega Domingos Monteiro da Silva, o escrivão Francisco Joaquim de Nazareth, o reposteiro Francisco José Ribeiro de Oliveira, o arruador Manoel José de Serpa, o mestre de embarcação Jacob José Lopes, o cabelereiro José Pinto Ramos, o escrivão Jacintho de Souza Ribeiro Guimarães e o empregado público (cargo específico não localizado) José Florencio de Lemos.

A presença repetitiva dos nomes de alguns pais ou encarregados nos leva a refletir, a partir de Carvalho (2007), que ocupar vários postos em diferentes locais traria experiência política. A mesma prática poderia se dar em escala reduzida, pois é possível observar sujeitos transitando por diferentes funções não apenas no âmbito da freguesia que residiam, mas também em outras. A circulação geográfica e a alternância de cargos em pequena escala trariam uma expertise administrativa e política em nível local e poderiam ser encaradas, por tais sujeitos, como importantes conquistas ou satisfazer as ambições daqueles que eram impedidos de almejar altos postos, em razão de sua condição social e econômica. Embora não tivesse poder suficiente para uma grande mobilidade social, poderiam adquirir importância, liderança ou distinção locais. 
Por outro lado, como Ilmar Mattos (1994) assinala, importava integrar segmentos sociais subalternos nas instituições que o Império forjava, como a Guarda Nacional ou "faze-lo participar das associações políticas que procuravam estender os braços do partido representado pela Coroa” (p. 268), ou seja, difundir a "civilização" consistia em garantir a adesão a uma ordem

[...] de um determinado conjunto de homens livres que não derivavam diferentemente dela, embora dela não deixassem de depender: notários e subdelegados de polícia; pequenos comerciantes e empregados públicos; clérigos e professores; e até mesmo um Cândido Neves - personagem do conto 'Pai contra Mãe' de Machado de Assis - que, premido pela pobreza, tornara-se 'pegador de escravos fugidos', passando a sentir-se 'bastante rijo para por ordem à desordem' (p. 269, aspas do autor).

O levantamento em torno dos pais e encarregados dos alunos da escola de Santa Rita mostra que vários estavam comprometidos com a política de governo da cidade, em menor ou maior grau de atuação, como no caso daqueles que ocuparam diferentes funções do aparato político e repressivo da Corte. Muito possivelmente, nesse conjunto de famílias, estavam aqueles a quem se destinava o controle e a vigilância e aqueles que eram responsáveis por mantê-los, cujos filhos dividiam, durante algum tempo, o mesmo espaço de experiência escolar.

"Para maior brilhantismo": espaços de sociabilidade, festejos e organização coletiva

Figura 22 - Anúncio da Irmandade do Divino Espírito-Santo

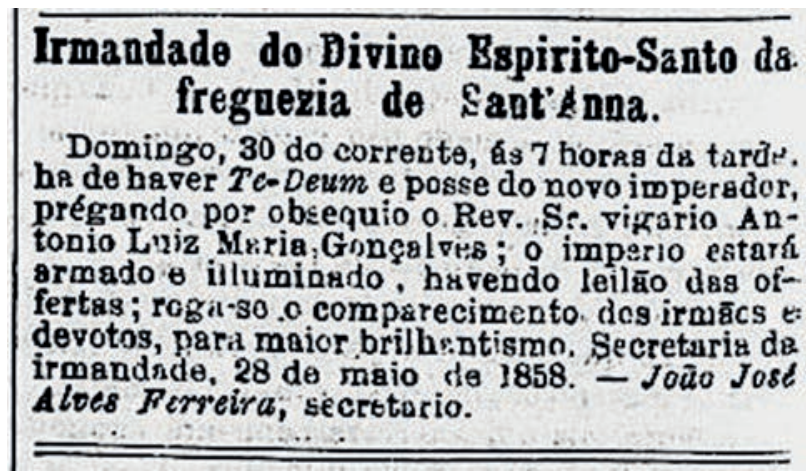

Fonte: Correio Mercantil, 28/05/1858, BN. 
O anúncio convite de que o "império estará armado e iluminado" (Correio Mercantil, 28 maio 1858) foi assinado pelo secretário da Irmandade do Divino Espírito-Santo da freguesia de Santana, João José Alves Ferreira, já mencionado como o fiscal que anunciou a proibição do entrudo em 1857. Da mesma irmandade fazia parte a costureira Fortunata Maria de Mendonça, responsável pelo aluno Pedro Fortunato Lamin, e que nela ocupara os cargos de "juíza da sagrada família” e de zeladora.

Confrarias, irmandades, ordens terceiras, devoções entre outras organizações de caráter religioso faziam parte do cotidiano de alguns pais e encarregados. Podiam reunir sujeitos de diferentes grupos sociais podendo nelas se estabelecer “solidariedade verticais" e também servir como associações de classe, profissão, nacionalidade e etnia (Abreu, 1999). A Irmandade do Divino Espírito-Santo era formada por pessoas de variadas situações sociais como médicos, comerciantes, carpinteiros e funcionários públicos, assinala Abreu.

Em geral, tais instituições possuíam o intuito de incentivar a devoção a um santo e procuravam atuar com fins beneficentes. As irmandades, organizadas por leigos, e as ordens terceiras, subordinadas às ordens religiosas, com maior poder e dinheiro tinham hospitais e atividades voltadas para o atendimento à população pobre.

A Confraria dos Mártires São Gonçalo Garcia e São Jorge, da qual era cobrador o cabeleireiro José Pinto Ramos, era uma irmandade de negros (Mattos, 2004), o que poderia a nos levar pensar que José também o fosse. No entanto, no caso de outra irmandade negra, a Irmandade de Santo Elesbão e Santa Efigênia, Reis (1996) assinala que os africanos oriundos da Costa da Mina, Cabo Verde, Ilha de São Tomé ou de Moçambique serviam como juízes, enquanto o cargo de tesoureiro seria sempre ocupado por um branco. Diante disso, torna-se complicado arriscar uma afirmação.

Embora tivessem finalidades diferentes, tanto a Irmandade do Divino Espírito-Santo da freguesia de Santana quanto a Confraria dos Mártires São Gonçalo Garcia e São Jorge estiveram ligadas por um tempo. Quando a Igreja Matriz da Irmandade foi demolida, ela se instalou provisoriamente na Igreja da confraria (AL, 1858).

As festas, no entanto, eram o momento máximo dessas instituições, fossem elas grandes ou pequenas, e João e Fortunata participavam de um grande evento que, segundo Abreu (1999), era considerado como o mais concorrido na cidade até meados do século XIX. A Festa do Divino Espírito-Santo da Irmandade de 
Santana ocupava uma imensa área no campo de mesmo nome, com barracas, atrações, como leilões de prendas e fogos, danças, música e público. Durante a festa, o imperador do Divino era escolhido, um menino menor de doze anos, e construído um império para abrigar o patrocinador das festividades.

As festas eram frequentadas por variados tipos. Ancorada em Moraes Filho, Abreu (1999) relata a presença da plebe, burguesia, escravos, aristocratas, homens de letras e fortes indícios de que a festa criava a oportunidade de encontro dos habitantes da cidade, inclusive mulheres,

Mais do que o encontro, favorecia a mistura dos escravos com os livres pobres, confundindo e difundindo entre si, independentemente da situação jurídica, gostos estéticos e práticas culturais diferentes, abrindo a possibilidade para se criar sempre algo diferente e novo (p. 102).

Foi nesse sentido que Abreu, em sua pesquisa sobre festas religiosas e cultura popular no Rio de Janeiro ao longo do século XIX, escolheu a festa do Divino Espírito Santo como eixo, para compreender "o exercício da religiosidade popular e sua relação dinâmica, criativa e política com os diferentes segmentos da sociedade, seus próprios pares, representantes do poder, autoridades locais, setores eruditos e reformadores católicos e protestantes" (p. 37-38), em um período atravessado pelos impasses entre um projeto político imperial de civilização europeizante e a prática de manifestações culturais vistas como perigosas e atrasadas.

Dessa forma, chama atenção o fato de João José ser também fiscal da freguesia de Santana, visto que os fiscais eram os auxiliares da Câmara Municipal no controle das condutas desordeiras e que a Câmara era responsável por autorizar a realização de festas na cidade (Abreu, 1999). Os fiscais recebiam parcos vencimentos, mas deviam saber ler e escrever para dar conta do regime de escrituração do serviço. Será que o fato de haver um fiscal na organização da festa conferia maior confiabilidade ao evento? Seria essa uma estratégia das irmandades para manutenção das festas ou mera coincidência? $\mathrm{O}$ fato é que no grupo pesquisado havia mais dois membros de outras irmandades que também ocupavam cargos de vigilância e repressão, como Domingos Thimoteo de Carvalho, fiscal suplente da freguesia de Santa Rita e oficial da Câmara Municipal; e Manoel Antonio Mafra, inspetor de quarteirão freguesia de Santa Rita (quadro 16). 


\section{Quadro 16 - Irmandades e Confrarias}

\begin{tabular}{|c|c|c|}
\hline N. & Nomes & Instituições e cargos \\
\hline 1 & $\begin{array}{l}\text { Adriano José da Silva } \\
\text { Braga }\end{array}$ & $\begin{array}{l}\text { Mesário da Irmandade do Santíssimo Coração de Jesus na igreja matriz } \\
\text { de S. José (AL, 1869). }\end{array}$ \\
\hline 2 & Belmiro Borges Pereira & "Andador" da Venerável Confraria da Imaculada Conceição (AL, 1853). \\
\hline 3 & $\begin{array}{l}\text { Domingos Thimoteo } \\
\text { de Carvalho }\end{array}$ & $\begin{array}{l}\text { Irmão vigário (AL, 1864) e irmão de Capela da Irmandade do Senhor } \\
\text { Santo Cristo dos Milagres (Diário de Notícias, } 21 \text { jun. 1871); } \\
\text { Secretário da mesa de fundação da Irmandade Santa Rita de Cassia } \\
\text { (Gazeta de Notícias, } 24 \text { maio 1878). }\end{array}$ \\
\hline 4 & $\begin{array}{l}\text { Florenciana Candida } \\
\text { Gomes da Costa }\end{array}$ & $\begin{array}{l}\text { Secretária da Irmandade do Senhor Santo Cristo dos Milagres, da fre- } \\
\text { guesia de Santa Rita (várias edições do Correio Mercantil de 1858). }\end{array}$ \\
\hline 5 & $\begin{array}{l}\text { Fortunata Maria de } \\
\text { Mendonça }\end{array}$ & $\begin{array}{l}\text { Juíza da Sagrada família da Irmandade do Divino Espírito Santo da } \\
\text { freguesia de Santana (AL, 1857, p. 193); } \\
\text { Zeladora da Irmandade do Divino Espírito Santo da freguesia de San- } \\
\text { tana (AL, 1858). }\end{array}$ \\
\hline 6 & $\begin{array}{l}\text { Francisco Joaquim de } \\
\text { Nazareth }\end{array}$ & $\begin{array}{l}\text { Secretário da irmandade que organizou a festa da Virgem Santíssima } \\
\text { Senhora da Conceição (Diário do Rio de Janeiro, } 13 \text { dez. 1851); } \\
\text { Secretário da Irmandade do Santíssimo Sacramento (Diário do Rio de } \\
\text { Janeiro, } 14 \text { dez. 1860). }\end{array}$ \\
\hline 7 & $\begin{array}{l}\text { Jacintho de Souza } \\
\text { Ribeiro Guimarães }\end{array}$ & $\begin{array}{l}\text { Irmão de capela da Irmandade de Santo Antonio dos Pobres e Nossa } \\
\text { Senhora dos Prazeres (AL, 1860). }\end{array}$ \\
\hline 8 & João José Alves Ferreira & $\begin{array}{l}\text { Consultor da Irmandade de Nosso Senhor do Bonfim (AL, 1857); } \\
\text { Escrivão (AL, 1857) e secretário da Irmandade do Divino Espírito Santo } \\
\text { da freguesia de Santana (Diário do Rio de Janeiro, } 19 \text { abr. 1858); } \\
\text { Anúncio de missa fúnebre de João promovida pela Ordem Terceira da } \\
\text { Imaculada Conceição (Diário do Rio de Janeiro, } 26 \text { nov. 1858). }\end{array}$ \\
\hline 9 & José Pinto Ramos & $\begin{array}{l}\text { Mesário da administração da Devoção de Nossa Senhora da Piedade } \\
\text { (Diário de Notícias, } 14 \text { out. 1886); } \\
\text { Cobrador da Confraria dos Mártires São Gonçalo Garcia e São Jorge } \\
\text { (Diário de Notícias, } 30 \text { ago. 1886). }\end{array}$ \\
\hline 10 & Luiz Rodrigues de Faria & $\begin{array}{l}\text { Na lista de irmãos e devotos que contribuíram com donativos para } \\
\text { o traslado da imagem do Senhor do Bonfim para Irmandade Nosso } \\
\text { Senhor do Bonfim (Correio Mercantil, } 11 \text { dez. 1857). }\end{array}$ \\
\hline 11 & Manoel Antonio Mafra & $\begin{array}{l}\text { Tesoureiro da Devoção Nossa Senhora da Conceição em São Francisco } \\
\text { na Prainha (Correio Mercantil, } 24 \text { set. 1857). }\end{array}$ \\
\hline 12 & $\begin{array}{l}\text { Manoel Ferreira dos } \\
\text { Santos Lima }\end{array}$ & $\begin{array}{l}\text { Definidor da Venerável Ordem Terceira de São Francisco da Penitência } \\
\text { (AL, 1873); } \\
\text { Mesário da Confraria Nossa Senhora das Dores da Candelária (AL, } \\
\text { 1874). }\end{array}$ \\
\hline
\end{tabular}

Fonte: Quadro elaborado pela autora com base nas informações levantadas nos jornais da Hemeroteca Digital da Biblioteca Nacional. 
Podemos observar pelo quadro que tais sujeitos ocupavam posições distintas dentro das irmandades e que alguns eram membros de mais de uma entidade. Segundo Reis (1996), o corpo dirigente das irmandades era chamado de mesa, da qual faziam parte juízes e provedores, que eram considerados os dirigentes máximos, e escrivães e tesoureiros que também tinham grande poder. Os outros cuidavam "da organização de festas e funerais, coleta de esmolas, assistência aos doentes, administração da capela e do culto divino” (p. 4). É bastante provável que vários outros pais e encarregados também tivessem sido membros de irmandades, mas não aparecem nesse conjunto de fontes de pesquisadas por não fazerem parte dos quadros administrativos.

A inserção nas irmandades consistia numa oportunidade de frequentar um espaço de estabelecimento de laços de solidariedade, numa forma de garantir assistência em momentos difíceis e por vezes um lugar de reconhecimento social numa sociedade hierarquizada e excludente (Oliveira, 1998). Para a Igreja, as irmandades representavam um conjunto de fiéis importantes para sua afirmação perante o Estado e, segundo Oliveira (1998, p. 3), para o Estado, "representavam uma perspectiva na manutenção da ordem social na medida em que dirigiam a vida dos fiéis dentro dos preceitos da religião oficial". No entanto, o autor assinala que a autonomia das irmandades preocupava as autoridades eclesiásticas e do governo, pois sustentavam uma perspectiva leiga e tradicional da religião que os eclesiásticos procuravam "depurar" e que o Estado procurava modernizar, alterando espaços e costumes que desestruturavam práticas costumeiras. Nesse jogo entre poder temporal e poder espiritual, as irmandades procuravam viver nos espaços intersticiais entre Estado e Igreja aproveitando-os para afirmar sua autonomia (Oliveira, 1998).

Alguns desses sujeitos também estavam envolvidos com outros espaços de sociabilidade, como sociedades de caráter cultural ou mutualista. Era outra maneira de assegurar alguma proteção e auxílio ou um caminho para participar mais ativamente na vida política, econômica e social da cidade. $\mathrm{O}$ professor Pardal também era membro de algumas dessas instituições listadas no quadro a seguir, como a Imperial Sociedade Amante da Instrução, a Sociedade Auxiliadora da Indústria Nacional e a Imperial Companhia de Seguro Mútuo contra fogo. 


\section{Quadro 17 - Sociedades e associações}

\begin{tabular}{|c|l|l|}
\hline N. & Nome & Instituição \\
\hline 1 & $\begin{array}{l}\text { Francisco Joaquim de } \\
\text { Nazareth }\end{array}$ & $\begin{array}{l}\text { Escriturário da Imperial Sociedade Amante da Instrução (Diário } \\
\text { do Rio de Janeiro, 05 ago. 1855). }\end{array}$ \\
\hline 2 & $\begin{array}{l}\text { Francisco Pereira da } \\
\text { Silva Vidal }\end{array}$ & $\begin{array}{l}\text { Membro da diretoria da Companhia Resgate Militar (Gazeta de } \\
\text { Notícias, 11 jul. 1876). }\end{array}$ \\
\hline 3 & João José Rebello & Sócio da Sociedade Alpha-literária (O Globo, 17/02/1875). \\
\hline 5 & $\begin{array}{l}\text { Joaquim Cosme } \\
\text { Monteiro }\end{array}$ & $\begin{array}{l}\text { Conselheiro da Imperial Sociedade Auxiliadora das Artes mecâ- } \\
\text { nicas e Liberais e Beneficente (Diário do Rio de Janeiro, 13 mar. } \\
1877) .\end{array}$ \\
\hline 6 & $\begin{array}{l}\text { Luiz Rodrigues de } \\
\text { f'Almeida }\end{array}$ & $\begin{array}{l}\text { Membro de loja maçônica (Boletim do Grande Oriente do } \\
\text { Brasil, 1878, p. 418). }\end{array}$ \\
\hline 7 & $\begin{array}{l}\text { Manoel Antonio } \\
\text { Safra }\end{array}$ & $\begin{array}{l}\text { Secretário adjunto da Sociedade de Baile Sylphide (AL, 1854). } \\
\text { Sete de Setembro com reunião na Rua de Mato-Grosso (Diário } \\
\text { do Rio de Janeiro, 11 out. 1863). }\end{array}$ \\
\hline 9 & $\begin{array}{l}\text { Theodoro Jansen } \\
\text { Manoel Ferreira dos }\end{array}$ & $\begin{array}{l}\text { Mordomo da Sociedade Portuguesa de beneficência (Diário do } \\
\text { Rio de Janeiro, 03 set. 1874); } \\
\text { Sócio da Comissão Central Portuguesa de Socorros (Diário do } \\
\text { Rio de Janeiro, 28 abr. 1874); } \\
\text { Membro de loja maçônica (Boletim do Grande Oriente do } \\
\text { Brasil, 1875); } \\
\text { Sócio da Associação Promotora da Instrução de Meninos (Diário } \\
\text { do Rio de Janeiro, 09 jun. 1875); } \\
\text { Conselheiro da Imperial Companhia de Seguro Mútuo contra } \\
\text { fogo (AL, 1885). }\end{array}$ \\
\hline $\begin{array}{l}\text { Sócio efetivo da Sociedade Auxiliadora da Indústria Nacional } \\
\text { Vice-presidente do Club Guarany (Diário de Notícias, 22 jun. } \\
1871) .\end{array}$ \\
\hline
\end{tabular}

Fonte: Quadro elaborado pela autora com base nas informações levantadas nos jornais da Hemeroteca Digital da Biblioteca Nacional.

Instituições que também promoviam eventos, como a de Manoel Antonio Mafra. Enquanto secretário da Sociedade Patriótica Sete de Setembro, cujas reuniões se davam na rua onde residia (como não há o número, não é possível ter certeza se acontecia em sua própria residência), convocou as pessoas para o toque da alvorada do dia 7 de setembro, na "varanda iluminada" instalada no Morro do Jogo da Bola (Correio Mercantil, 06 jul. 1863). O evento seria seguido de missa na 
capela de São Francisco da Prainha, onde funcionava a Devoção Nossa Senhora da Conceição, da qual também fazia parte. Na nota, Mafra também convocou as sociedades de música a estarem presentes no evento. Podemos igualmente observar que o trânsito dos sujeitos por diferentes instituições favorecia o intercâmbio de atividades realizadas por elas. Tal evento, por exemplo, mobilizou os membros da Sociedade Patriótica, da Sociedade Musical Monarquista e da Capela São Francisco da Prainha e ainda procurava mobilizar outras por meio da nota de jornal.

Para Viscardi (2004), as associações cumpriram um papel fundamental na sociedade civil, pois proporcionavam amparo aos desvalidos, garantiam aposentadoria aos trabalhadores, ainda que parcial: "se constituíam como espaços de lazer e solidariedade, contribuíam como reforço de identidades coletivas e chegavam até a funcionar como instrumentos facilitadores do processo de construção de cidadania” (p. 100).

Cabe lembrar que José Pinto Ramos, que consta no quadro das irmandades, mas não neste último, era cabeleireiro dos Teatros de São Pedro e de Santa Theresa, o que de certa forma o inseria na convivência desse espaço artístico. $\mathrm{O}$ teatro também poderia ser utilizado com fins beneficentes, como a já mencionada apresentação beneficente no Teatro São Pedro de Alcântara em favor da viúva de João José Alves Ferreira e filhos, e a apresentação em benefício da Associação de Socorros Mútuos Liga Operária (Gazeta de Notícias, 24 set. 1882). Coincidentemente ou não, os filhos ou tutelados que foram identificados teriam participação maior nas sociedades e associações do que nas irmandades.

A subscrição de listas e abaixo-assinados era outra prática recorrente da época e da qual tomaram parte alguns sujeitos (quadro 18). As listas localizadas tinham intuitos diversos, como fazer arrecadação para a festa de chegada das majestades, encanamento do Rio Maracanã e estátua equestre de D. Pedro I, para a qual o professor Pardal constituiu sua própria lista, contando inclusive com o nome de vários alunos. Pardal tinha interesses na organização da lista, mas ao fazer seus alunos participarem também propiciou uma oportunidade de iniciá-los nas agências sociais, na prática de organização coletiva em prol de um objetivo comum, bem como dos usos da leitura e escrita na sociedade. 
Quadro 18 - Listas e abaixo-assinados

\begin{tabular}{|c|c|c|}
\hline N. & $\begin{array}{l}\text { Nome dos pais/ } \\
\text { encarregados }\end{array}$ & Lista e abaixo-assinados \\
\hline 1 & $\begin{array}{l}\text { José Joaquim Ferreira } \\
\text { Leal }\end{array}$ & $\begin{array}{l}\text { Lista para estátua equestre de D. Pedro I, lista do professor } \\
\text { Pardal (Diário do Rio de Janeiro, } 22 \text { dez. 1855); } \\
\text { Lista para festejar a chegada de suas majestades imperiais (Cor- } \\
\text { reio Mercantil, } 30 \text { abr. 1860). }\end{array}$ \\
\hline 2 & $\begin{array}{l}\text { Manoel Machado } \\
\text { Fagundes }\end{array}$ & $\begin{array}{l}\text { Abaixo-assinado contra fechamento do cemitério de São Fran- } \\
\text { cisco de Paula no Catumby (Correio Mercantil, } 22 \text { ago. 1851). }\end{array}$ \\
\hline 3 & $\begin{array}{l}\text { Alexandre Soares } \\
\text { Pinheiro }\end{array}$ & $\begin{array}{l}\text { Lista em favor das vilas de Diamantina e do Príncipe (Diário do } \\
\text { Rio de Janeiro, } 20 \text { mar. 1834). }\end{array}$ \\
\hline 4 & $\begin{array}{l}\text { Theodoro Jansen } \\
\text { Muller }\end{array}$ & $\begin{array}{l}\text { subscritor da lista de donativos para festa de chegada de suas } \\
\text { majestades imperiais (Correio Mercantil, } 30 \text { abr. 1860); } \\
\text { Solenizar a chegada de suas majestades imperiais (Gazeta de } \\
\text { noticias, } 29 \text { ago. 1877). }\end{array}$ \\
\hline 5 & $\begin{array}{l}\text { Manoel José da } \\
\text { Rocha Paranhos }\end{array}$ & $\begin{array}{l}\text { subscritor da lista de donativos para festa de coroação de Pedro } \\
\text { II (Diário do Rio de Janeiro, } 19 \text { jul. 1841). }\end{array}$ \\
\hline 6 & $\begin{array}{l}\text { Jacintho de Souza } \\
\text { Ribeiro Guimarães }\end{array}$ & $\begin{array}{l}\text { Abaixo-assinado de moradores contra a calha de despejos } \\
\text { construída em frente às suas residências na Rua de Santa Luzia } \\
\text { (Correio Mercantil, } 11 \text { nov. 1863). }\end{array}$ \\
\hline 7 & $\begin{array}{l}\text { Joaquim José Pereira } \\
\text { d'Almeida }\end{array}$ & $\begin{array}{l}\text { Subscrição de lista de oficiais da guarda nacional para a constru- } \\
\text { ção de um arco luminoso para chegada do imperador (Diário do } \\
\text { Rio de Janeiro, } 17 \text { abr. 1846); } \\
\text { Subscritor da lista para estatua equestre de D. Pedro I (Diário do } \\
\text { Rio de Janeiro, } 15 \text { mar. 1856). }\end{array}$ \\
\hline 8 & $\begin{array}{l}\text { Manoel José de } \\
\text { Serpa }\end{array}$ & $\begin{array}{l}\text { Morador de São Cristóvão que subscreveu lista para “encana- } \\
\text { mento do Maracanã” (Diário do Rio de Janeiro, } 23 \text { set. 1830); } \\
\text { Doação de } 5 \% \text { do salário para defesa dos portos (Diário do Rio } \\
\text { de Janeiro, } 20 \text { jan. 1863). }\end{array}$ \\
\hline 9 & $\begin{array}{l}\text { Leopoldino das } \\
\text { Chagas Oliveira }\end{array}$ & $\begin{array}{l}\text { subscrição de lista promovida pela Imperial Sociedade Auxilia- } \\
\text { dora das Artes mecânicas e Liberais e Beneficente para Estátua } \\
\text { Equestre de D. Pedro I (Correio Mercantil, } 14 \text { mar. 1855). }\end{array}$ \\
\hline 10 & $\begin{array}{l}\text { Luiz Antonio da } S^{a} \\
\text { Beltrão }\end{array}$ & $\begin{array}{l}\text { Para estátua equestre de D. Pedro I, lista do professor Pardal } \\
\text { (Diário do Rio de Janeiro, } 22 \text { dez. 1855). }\end{array}$ \\
\hline
\end{tabular}

Fonte: Quadro elaborado pela autora com base nas informações levantadas nos jornais da Hemeroteca Digital da Biblioteca Nacional.

A organização de uma lista, por Pardal, em favor da estátua equestre do ex-Imperador Dom Pedro I sugere algumas questões, como os interesses políticos que poderiam estar envolvidos em uma demonstração pública de apoio à figura de um representante do regime monárquico e a capacidade de recrutar pessoas para apoiar algo. Mas a aceitação dos pais a subscreverem uma lista 
também sugere outros interesses. Ter seus nomes numa lista como essa ou para os festejos da chegada da família imperial pode representar a adesão ao regime monárquico e, portanto, à ordem instituída, corroborando para a construção de uma imagem de boa conduta e moralidade, necessária para exercer certas atividades e, inclusive, entrar em determinadas irmandades e associações, ou mesmo receber benefícios ou a "caridade" de instituições. Oliveira (1998) ressalta que, na segunda metade do Oitocentos, o discurso filantrópico incorporou a noção de benemerência, ou seja, o pobre deveria ser merecedor do benefício. Tal perspectiva foi assumida por irmandades como a Ordem Terceira da Imaculada Conceição, da qual fazia parte o fiscal João José Alves Ferreira, que passou a exigir das "desvalidas", desejosas de serem admitidas no asilo, um atestado de boa conduta emitido pelo inspetor de quarteirão (Oliveira, 1998).

Por outro lado, ter seu nome em listas reivindicatórias, como a realizada contra o fechamento do cemitério de São Francisco de Paula, contra a calha de despejos construída em frente às suas residências ou a favor do encanamento do Rio Maracanã, mostra que tais sujeitos buscavam intervir nos "problemas da ordem" existente, contra as quais estavam insatisfeitos. A intervenção requeria organizar o procedimento reivindicatório; mobilizar sujeitos; escrever seu próprio nome em um documento ou, no caso dos que não soubessem, recorrer a quem pudesse fazê-lo; entregar o documento à autoridade competente; e até mesmo publicá-lo nos jornais, instrumento que serviu de fonte para o quadro em questão. Várias etapas a cumprir que mobilizaram moradores, ajudaram a constituir um sentimento de coletividade e de atuação na localidade em que viviam, uma agência e experiência coletiva, enfim "para maior brilhantismo" na cidade.

Observa-se que os pais e encarregados analisados estavam intensamente comprometidos com as redes existentes na sociedade da Corte. Envolvidos social e politicamente no governo, na economia, na cultura, nos espaços de sociabilidade e de solidariedade, tinham sua parcela de participação na ordem, ou desordem, da cidade, subvertendo-a, contornando-as, adquirindo experiências diversas, criando agências nas contingências, na emergência de um campo para mudança, disputa e resistência. 
O mapeamento das atividades mostra também a rede de relações estabelecida pelo professor Pardal com vários desses sujeitos na cidade, evidenciando conexões sociais, culturais, políticas. O fato do nome dele constar na nota de missa fúnebre de José Joaquim Ferreira Leal demonstra que algumas relações eram muito próximas e que mesmo com a morte dos pais iriam continuar com os filhos, como veremos a seguir.

As informações analisadas apontam para os modos de participação que sujeitos da escola engendravam na cidade, suas maneiras de se inserir em diferentes lugares, o trabalho que executavam, espaços sociais frequentados e atividades realizadas para se sustentar e se divertir. Mostram, assim, um panorama das experiências de uma vida dinâmica, cujo cotidiano era permeado de estratégias de sobrevivência, tensões, contradições e festividades na Capital do Império, e da qual faziam parte o professor, seus alunos e seus responsáveis. A dinâmica também nos dá a ver os outros espaços de aprendizado no entorno da Escola Pública de Santa Rita.

\section{"Sabe ler": os rumos e percursos de ex-alunos}

Figura 23 - Jorge Augusto Corrêa, ex-aluno de Pardal

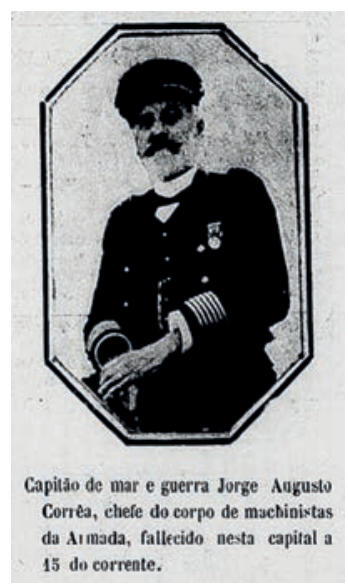

Fonte: Revista da Semana, 19 maio 1907, Biblioteca Nacional.

A figura 23 mostra Jorge Augusto Corrêa, chefe do corpo de máquinas da Marinha de Guerra (Revista da Semana, 19 maio 1907). Ele foi nomeado maquinista de $3^{\text {a }}$ Classe da Marinha em 10 de abril de 1869 . Fez carreira dentro da Marinha, tornando-se tenente, capitão-tenente, capitão de fragata graduado 
e capitão de mar e guerra. Havia ganho uma medalha de ouro por ter mais de 20 anos de serviço militar e no ano de sua morte, 1907, contava com 42 anos de atuação. Jorge estudou na escola da freguesia de Santa Rita juntamente com seu irmão Augusto José Correa que também se tornou maquinista do Arsenal da Marinha, mas morreu aos 27 anos, em 1873. O endereço que constava no mapa de matrícula, Rua do Livramento n. ${ }^{\circ} 104$, pertencia, segundo o Almanak Laemmert, a José Antonio Pereira Leal, adido da Contadoria Geral do Ministério da Marinha (AL, 1855). José Antonio era padrinho de Emília Correa, irmã de Jorge e Augusto (Diário do Rio de Janeiro, 11 set. 1871), e pode ter agenciado a inserção de ambos os irmãos na Marinha.

Jorge, assim como outros ex-alunos, seguiu carreira militar e esteve na Guerra do Paraguai. O Exército e a Marinha emergiam como opções para as classes populares para aprendizagem de um ofício e obter benefícios, além da remuneração (Cunha, 2006). O ingresso nas companhias de Aprendizes Menores dos Arsenais de Guerra poderia ser encarado como uma oportunidade de mobilidade social, mesmo que restrita. Para Carvalho (2007), nas burocracias profissionalizadas, como a militar, que definiam com mais rigidez suas fronteiras, a subida até os cargos mais altos era sempre possível para quem conseguisse adentrar no setor.

\section{Quadro 19 - Ex-alunos em ocupações militares}

\begin{tabular}{|c|l|l|}
\hline N. & Nomes & Atividades \\
\hline 1 & $\begin{array}{l}\text { Vicente Lauro Gomes } \\
\text { da Costa }\end{array}$ & $\begin{array}{l}\text { Consta na lista de aspirantes do ano de 1858 no Quartel da Companhia } \\
\text { de Aspirantes a Guardas-Marinhas (AL, 1858, p. 228); listado como } \\
\text { soldado do corpo de artilharia de Mato-Grosso (Ministério da Guerra, } \\
\text { julho de 1860, p.14); Florenciana Gomes da Costa pede baixa de seu } \\
\text { filho soldado do corpo de artilharia de Mato-Grosso (Ministério da } \\
\text { Guerra, jul. 1860, p. 22). }\end{array}$ \\
\hline 2 & $\begin{array}{l}\text { Candido Coelho da } \\
\text { Costa }\end{array}$ & $\begin{array}{l}\text { Reformado em 1884 do cargo de soldado do batalhão de engenheiros } \\
\text { por ter mais de 30 anos de serviço (Gazeta de Notícias, 18 nov. 1884). }\end{array}$ \\
\hline 3 & $\begin{array}{l}\text { Simeão Joaquim do } \\
\text { Nascimento }\end{array}$ & $\begin{array}{l}\text { Guardião extranumerário do corpo de oficiais marinheiros (A Nação, 13 } \\
\text { mar. 1874). }\end{array}$ \\
\hline 4 & $\begin{array}{l}\text { Antonio Quintiliano de } \\
\text { Castro e Silva (Ceará) }\end{array}$ & $\begin{array}{l}\text { Aprovado simplesmente em aritmética na escola da marinha (Correio } \\
\text { Mercantil, 17 fev. 1862); nomeado aspirante na escola da marinha (Cor- } \\
\text { reio Mercantil, 01 mar. 1862); promovido a guarda marinha (Correio } \\
\text { serviços prestados na Guerra do Paraguai cavaleiro da Ordem de Cristo } \\
\text { (Correio Mercantil, 13 e 14 abr. 1865); enquanto 1 }{ }^{\circ} \text { tenente da armada } \\
\text { nacional foi nomeado cavaleiro da Ordem de São Bento de Aviz (Gazeta } \\
\text { de Notícias, 27 jun. 1878); nota de elogio a sua coragem durante o nau- } \\
\text { frágio do navio que pilotava (Gazeta da Tarde, 28 abr. 1883). }\end{array}$ \\
\hline
\end{tabular}




\begin{tabular}{|c|c|c|}
\hline 5 & José Maria Feliciano & $\begin{array}{l}\text { Registro em oficio do presidente da província do Rio Grande do Sul de } \\
\text { que a mãe de José Maria Feliciano, praça do } 1 .^{\circ} \text { regimento de cavalaria } \\
\text { ligeira, pede que ele seja considerado voluntário (Boletim do expediente } \\
\text { do governo, Ministério da Guerra, } 1860, \text { p. } 7 \text { ). }\end{array}$ \\
\hline 6 & $\begin{array}{l}\text { Luis Adolpho da Silva } \\
\text { Monteiro }\end{array}$ & $\begin{array}{l}\text { Consta que sua mãe Rosa Isabel Monteiro recebeu pensão pelos faleci- } \\
\text { dos filhos voluntários da pátria Antonio Claudino da Silva Monteiro e } \\
\text { Luis Adolpho da Silva Monteiro (Gazeta de Notícias, } 13 \text { mar. 1890). }\end{array}$ \\
\hline 7 & $\begin{array}{l}\text { Antonio Claudino da } \\
\text { Silva Monteiro }\end{array}$ & $\begin{array}{l}\text { Consta na lista oficiais feridos do } 24 .^{\circ} \text { Corpo de Voluntários da guerra } \\
\text { do Paraguai (Correio Mercantil, } 27 \text { mar. 1865); consta que sua mãe } \\
\text { Rosa Isabel Monteiro recebeu pensão pelos falecidos filhos voluntários } \\
\text { da pátria Antonio Claudino da Silva Monteiro e Luis Adolpho da Silva } \\
\text { Monteiro (Gazeta de Notícias, } 13 \text { mar. 1890). }\end{array}$ \\
\hline 8 & $\begin{array}{l}\text { Manoel Carneiro de } \\
\text { Mattos }\end{array}$ & $\begin{array}{l}\text { Aparece na lista de alunos do depósito de aprendizes artilheiros como } \\
\text { anspeçada de } 1^{\text {a }} \text { classe (Diário do Rio de Janeiro, } 28 \text { dez, 1873). }\end{array}$ \\
\hline 9 & $\begin{array}{l}\text { Luiz Cavalcante de } \\
\text { Campos Mello }\end{array}$ & $\begin{array}{l}\text { Aprovado no exame feito na Escola Central (Correio Mercantil, } 30 \text { out. } \\
\text { 1862); Secretário do escritório do engenheiro chefe da estrada de ferro } \\
\text { D. Pedro II (O Globo, } 13 \text { set. 1876); o engenheiro pediu exoneração do } \\
\text { cargo de ajudante do } 1^{\text {a }} \text { classe da estrada de ferro (O Repórter, } 12 \text { jan. } \\
\text { 1879) }\end{array}$ \\
\hline 10 & $\begin{array}{l}\text { Oscar Ferreira dos } \\
\text { Santos Lima }\end{array}$ & $\begin{array}{l}\text { Praça reformado em } 1869 \text {, era sargento ajudante do } 51 .{ }^{\circ} \text { Corpo de } \\
\text { voluntários da Pátria (Opinião liberal, } 25 \text { jun. } 1869) \text {; recebeu pensão } \\
\text { enquanto sargento ajudante do } 51^{\circ} \text { Corpo de voluntários da Pátria por } \\
\text { ter ficado inutilizado por ferimentos (AL, } 1870 \text {, suplemento). }\end{array}$ \\
\hline 11 & Jorge Augusto Correa & Maquinista do Arsenal da Marinha (ver introdução do item). \\
\hline 12 & Augusto José Correa & $\begin{array}{l}\text { Augusto, } 24 \text { anos, maquinista do Arsenal da Marinha, foi submetido a } \\
\text { procedimento médico para tratar de sequelas da sífilis relatado no Anais } \\
\text { Brasilienses de Medicina de } 1868 \text { (p. } 320-326 \text { ); morreu aos } 27 \text { anos de } \\
\text { "accesso pernicioso" (A Nação, } 09 \text { jan. 1873). }\end{array}$ \\
\hline 13 & $\begin{array}{l}\text { Bernardo Francisco de } \\
\text { Mendonça }\end{array}$ & $\begin{array}{l}\text { Cabo voluntário da pátria adido ao } 14^{\circ} \text { batalhão de infantaria (Diário do } \\
\text { Rio de Janeiro, } 05 \text { fev. 1867). }\end{array}$ \\
\hline 14 & $\begin{array}{l}\text { Antonio Galdino de } \\
\text { Jesus Mafra }\end{array}$ & $\begin{array}{l}\text { Aluno Alferes de Infantaria da Escola Geral de Tiro de Campo Grande } \\
\text { (AL, 1876); Lista de qualificação de votantes da freguesia de Campo } \\
\text { Grande, } 29 \text { anos, casado, sabe ler, militar, escola de tiro, filho de Manuel } \\
\text { Antonio Mafra, elegível (Diário do Rio de Janeiro, } 24 \text { jul. 1876); apro- } \\
\text { vado plenamente no exame de tiros da Escola de Tiro de Campo Grande } \\
\text { (O Globo, } 14 \text { nov. 1876). }\end{array}$ \\
\hline 15 & $\begin{array}{l}\text { Francisco Lopes } \\
\text { Barbosa }\end{array}$ & $\begin{array}{l}\text { Aluno do Depósito de Aprendizes artilheiros, anúncios de exames da } \\
\text { escola realizados na Fortaleza de São João listam o nome dele como } \\
\text { cabo (Diário do Rio de Janeiro, } 20 \text { nov. 1867, } 02 \text { dez. 1867; Correio } \\
\text { Mercantil, } 26 \text { nov. 1867). }\end{array}$ \\
\hline
\end{tabular}

Fonte: Quadro elaborado pela autora com base nas informações levantadas nos jornais da Hemeroteca Digital da Biblioteca Nacional. 
Deste grupo de alunos que exerceram atividades militares, alguns estudaram no Depósito de Aprendizes Artilheiros, na Escola Central, na Escola Geral de Tiro de Campo Grande e na Escola da Marinha. Espaços que refletem a ênfase na educação e as iniciativas no campo tomadas pelos militares ao longo do Império, principalmente após 1850 (Alves, 2002 e Carvalho, 2007).

O Depósito de Aprendizes Artilheiros surgiu durante a Guerra do Paraguai por decreto de 1866 e marcou o início da formação militar destinada aos menores de idade (Alves, 2002). Seu formato tinha a ver com o modo de recrutamento, por meio de captura. Segundo Alves, os jovens serviam por seis anos e geralmente eram encaminhados para corpos distantes de suas casas com intuito de evitar deserções:

Para o depósito eram levados os voluntários, mas também os recrutas menores de dezenove anos; os órfãos e abandonados, assim como os jovens apresentados pelos pais, com prioridade para os filhos de praças, e, ainda, os artesãos dos arsenais de guerra que não tivessem demonstrado aptidão necessária para as artes (Alves, 2002, p. 269, grifos da autora).

Embora a faixa etária para o depósito devesse ser entre 12 e 19 anos, a pesquisa de Alves aponta que não era um esquema rígido, na medida em que era possível observar no ano de 1866 alunos com idades abaixo e acima dos limites estabelecidos, havendo alunos com 10 e 24 anos de idade.

Segundo relatório trazido por Alves, o objetivo da instituição era formar artilheiros com a necessária instrução e moralidade e oferecer abrigo aos meninos de famílias pobres, por meio de conteúdos escolares e instrução militar. Aqueles que se destacassem em seu desempenho teriam oportunidade de ascensão. Para o Depósito foram pelo menos dois ex-alunos de Pardal: Manoel Carneiro de Mattos e Francisco Lopes Barbosa. Manoel tinha como responsável Francisca Carneiro de Mattos e Francisco, o padre de mesmo nome que faleceu em 1856.

A Escola Central fazia parte da formação militar para habilitação de oficiais em engenharia e artilharia, bem como de geógrafos e topógrafos, que exigia um compromisso com os conhecimentos científicos (Alves, 2002). Na Escola estudou Luiz Cavalcante de Campos Mello, cujo responsável era o conselheiro Campos Mello, que se tornou engenheiro e, em 1876, constava como secretário do escritório do engenheiro chefe da Estrada de Ferro D. Pedro II ( $O$ Globo, 13 set. 1876). 
A Escola Geral de Tiro de Campo Grande foi criada em 1859 para aprimorar a organização da Escola de Instrução de Tiro, fundada em 1858, com objetivo de formar instrutores para os corpos de infantaria e artilharia do exército que faziam uso de armamentos pesados e de portáteis. Durante a Guerra ela foi fechada, sendo reaberta após o fim do conflito. Ao ganhar novo regulamento em 1873, foi revalorizada e passou a ser campo de realização de experimentos. Possuía acomodações para 84 alunos. Aqueles que faziam o curso anual recebiam aulas de ciências físicas e matemáticas, confecção de pólvora e munições, apreciação e manejo de armas. Ao final do ano letivo, os alunos faziam exames para instrutor de tiro, em presença de uma comissão julgadora.

Alves (2002) ressalta que não era fácil obter aprovação em razão de uma formação impregnada de forte exigência intelectual, mas não isso foi problema no caso de Antonio Galdino de Jesus Mafra que foi aprovado "plenamente". Antonio Galdino aparece no Almanak Laemmert de 1876 como alferes de infantaria que comandava o serviço da Escola, feito por um destacamento de praças de diversos corpos da Corte.

Alguns dos alunos listados participaram da Guerra do Paraguai por serem militares, outros como parte do "Corpo de Voluntários da Pátria", criado em 1865 e que assegurava soldo aos cidadãos entre 18 e 50 anos que se alistassem. Nesse grupo, havia muitos libertos e escravizados motivados pela promessa de alforria. O maquinista Jorge Augusto Correa também fez "campanha do Paraguai" pela qual ganhou outra medalha, a de Aviz. Parece ter sido muito prestigiado como sugere a nota de jornal de 1907 que afirma que superiores e subordinados sentiram muito a morte de Jorge.

Mas nem todos voltaram da Guerra. A nota sobre a pensão recebida pela mãe Rosa Isabel Monteiro confirma a morte de Antonio Claudino da Silva Monteiro (Gazeta de Notícias, 13 mar. 1890), que constava na lista de oficiais feridos do $24 .^{\circ}$ Corpo de Voluntários da Guerra do Paraguai (Correio Mercantil, 27 mar. 1865), e de seu irmão Luis Adolpho da Silva Monteiro.

O filho do professor Pardal, Candido Matheus de Faria Pardal Júnior, também lutou na Guerra e esteve na lista dos feridos da Batalha de Curupaity (O Publicador, 31 dez. 1866). Mas ele sobreviveu e, na condição de sargento ajudante do Asilo dos Inválidos da Corte, foi reformado por achar-se impossibilitado de exercer suas funções por ferimento em combate (Correio Mercantil, 07 jan. 1867). No mesmo ano, o Imperador lhe concedeu a "honra" do posto de Alferes do 12. Corpo de Voluntários da Pátria, pelos serviços prestados na Guerra (O Correio Mercantil, 
22 fev, 1867). A imprensa também anunciou homenagens a Pardal Júnior, um dos "heróis em Curupaity", ao enaltecer os bravos da Guerra do Paraguai (Correio Mercantil, 17 out. 1867) pelo ato de patriotismo (Opinião Liberal, 19 out. 1867). Em 1870, foi concedida a "honra de capitão" ao filho de Pardal, ainda pelos serviços prestados no conflito (Diário do Rio de Janeiro, 10 maio 1870), mesmo ano em que ele solicita ser agregado à $1^{\text {a }}$ Companhia de Infantaria do Corpo Policial (Diário do Rio de Janeiro, 08 jun. 1870).

A Guerra e seus posteriores desdobramentos também mobilizaram sujeitos da escola por outras vias como a doação de parcela dos salários para o combate, como fizeram professores públicos primários da Corte. Em 1868, Pardal fez parte de uma comissão para organizar os festejos da "vitória" na Guerra, assim como Domingos Thimoteo de Carvalho e seu filho, ex-aluno de Pardal, Leopoldo Thimoteo de Carvalho. Anos depois, o ex-aluno Antonio Galdino de Jesus Mafra também assinou subscrição para monumento aos bravos falecidos na Batalha de Riachuelo (O Globo, 11 jun. 1875).

Entretanto, na luta cotidiana para se estabelecer, outra guerra era travada. Seguindo a carreira do comércio, em permanente tensão com os códigos de posturas e normatizações da Câmara Municipal, exercendo ofícios variados, como de carpinteiro, ferreiro, pedreiro também regulados pelo governo, ou submetidos às pressões existentes na carreira do funcionalismo público de baixo escalão, sujeitos valiam-se de estratégias de sobrevivência, de inserção em um mundo de trabalho marcado pelo regime escravista ou de estabelecimento nos círculos sociais e políticos da cidade.

A experiência de escolarização igualmente faz parte desse processo de inserção na cidade. A saída da escola, seja por conclusão dos estudos ou por iniciação em outras atividades, representa uma etapa em suas trajetórias de vida - etapa que recebeu registros nos mapas de matrícula da Escola Pública de Santa Rita. Ao anotar a saída do aluno, o professor fazia uma observação, explicando a razão ou informando "não participou o motivo". Os casos em que foram informadas as razões encontram-se no quadro a seguir. 
Quadro 20 - Motivos da evasão de alunos durante o ano de 1855

\begin{tabular}{|c|c|c|c|}
\hline N. & Nome & $\begin{array}{l}\text { Idade na } \\
\text { saída }\end{array}$ & Motivo registrado no mapa \\
\hline 1 & Manoel da Costa Bastos & 12 & $\begin{array}{l}\text { Por ter chegado a } 10^{\text {a }} \text { classes de leitura, escrita } \\
\text { e contabilidade. }\end{array}$ \\
\hline 2 & Luiz de Souza Ribeiro Guimarães & 15 & \multirow{3}{*}{$\begin{array}{l}\text { Os três irmãos saíram por terem que se mudar } \\
\text { para fora da cidade. }\end{array}$} \\
\hline 3 & $\begin{array}{l}\text { Jacintho de Souza Ribeiro Gui- } \\
\text { marães }\end{array}$ & 11 & \\
\hline 4 & João de Souza Ribeiro Guimarães & 9 & \\
\hline 5 & $\begin{array}{l}\text { Amâncio Lourenço Gomes da } \\
\text { Costa }\end{array}$ & 14 & Participou ir seguir estudos superiores. \\
\hline 6 & Candido Coelho da Costa & 14 & Participou ir seguir um ofício. \\
\hline 7 & Simeão Joaquim do nascimento & 11 & Participou ir seguir um ofício. \\
\hline 8 & José Manoel Gonçalves Bastos & 10 & Participou ir aprender um oficio. \\
\hline 9 & Joaquim José Alves & 10 & Participou ir seguir estudos superiores. \\
\hline 10 & Francisco Gomes Rangel & 13 & Participou ir seguir o comércio. \\
\hline 11 & $\begin{array}{l}\text { Sisemando (ou Dilermando) } \\
\text { Felisberto da Silva }\end{array}$ & 13 & Participou ir aprender um oficio. \\
\hline 12 & Sabino Gomes Braga & 11 & Participou ir seguir estudos superiores. \\
\hline
\end{tabular}

Fonte: Quadro elaborado pela autora com base nos mapas de matrícula de 1855 localizados no AGCRJ.

Dessa listagem, observamos que quatro alunos alegavam ter saído para aprender ou seguir um ofício, o mais novo com 10 anos, e um para seguir o comércio. Outros três saíram para seguir estudos superiores, entre eles, Amâncio Lourenço Gomes da Costa, o aluno mais antigo da escola, com matrícula de 1849. Seu irmão Vicente Lauro Gomes da Costa, que nesse período ainda estava matriculado, aparece na lista de aspirantes do ano de 1858 do Quartel da Companhia de Aspirantes a Guardas-Marinhas.

Sabino Gomes Braga que informou que iria seguir estudos superiores tinha como responsável o Comendador Bernardo Gomes Braga, um fazendeiro de café. De acordo com as listas de qualificação de votantes de 1877, Sabino havia se tornado comerciante. Henrique Gomes Braga - que também tinha como responsável o comendador, mas cujas listas de votantes acusam ser filho de José Gonçalves Braga - estudou na Academia de Belas Artes, onde ganhou medalhas, e também em Paris. Tornou-se organista da Capela Imperial e pianista conhecido nos noticiários. Interessante destacar que, em 1853, ambos os meninos podem 
ser vistos na relação de alunos do Colégio de São Pedro de Alcântara (Correio Mercantil, 18 dez. 1853), localizado na Rua do Livramento, o que levanta a indagação do motivo que teria levado a trocarem o colégio pela escola pública.

Os irmãos Luiz de Souza Ribeiro Guimarães e Jacintho de Souza Ribeiro Guimarães se tornaram guardas da Alfândega da Corte. Sobre o terceiro irmão, João, não foram localizadas informações. Pelo levantamento nos jornais, mais dez ex-alunos fizeram parte do funcionalismo público de baixo escalão: Alfredo Candido Pereira de Souza, guarda do corpo de cavalaria da Guarda Nacional (Correio Mercantil, 23 ago. 1865); Júlio Ribeiro de Oliveira Leão, segundo lista de qualificação de votantes, empregado público (Diário do Rio de Janeiro, 22 jul. 1876); Alexandre Luis da Costa Prates, empregado no Foro (Diário do Rio de Janeiro, 25 jul. 1876 e 06 fev. 1877); os irmãos Manoel Antonio de Oliveira Borges, contínuo da Fortaleza da Conceição (AL, 1878), Domingos de Oliveira Borges, empregado da Alfândega (Gazeta de Notícias, 26 jan. 1889); Matheus de Oliveira Borges foi professor adjunto, comerciante proprietário de um armazém de materiais de obras, praticante da Diretoria Geral da Tomada de Contas (AL, 1880) e, dois anos depois, foi nomeado escriturário da mesma repartição; João Baptista Pereira de Almeida, empregado (escriturário do pessoal de tráfego) da administração da Estrada de Ferro D. Pedro II (AL, 1867); Francisco Xavier da Silva Moura, empregado público (Diário do Rio de Janeiro, 20 jul. 1876); Francisco Pereira da Silva Vidal, escriturário do Tesouro Nacional (Gazeta da Tarde, 19 nov. 1883); e João Luis da Costa Oliveira Junior, guarda da Alfândega (AL, 1870) e depois praticante da Recebedoria do Rio de Janeiro (Gazeta de Notícias, 11 set. 1880), trajetória que não se encerrou com esta ocupação, como veremos adiante.

Um grupo - apesar dos pais ou encarregados terem sido empregados públicos - seguiu carreira diversa, como Henrique de Oliveira Lemos, Eugênio José de Serpa e Carlos Rodrigues de Faria, que se tornaram negociantes, conforme consta nas listas de qualificação de votantes. As listas, contudo, não especificam o tipo de negócio, categoria bastante ampla que poderia abarcar diferentes atividades. Outros seguiram o ofício de negociante ou herdaram os negócios da família, como Ezequiel Borges Pereira, Clarindo Gomes Rangel, Manoel Machado Fagundes e o já mencionado Matheus de Oliveira Borges.

Ofícios como ferreiro, correeiro, maquinista, marmorista, tipógrafo, mestre de embarcação, pedreiro e "artista”, termo genérico que engloba muitas atividades, também foram seguidos por vários ex-alunos, como Francisco Roberto 
Pimenta que parece ter conseguido se estabelecer como marmorista, podendo inclusive colocar anúncios nos jornais para divulgar seus serviços.

Figura 24 - Anúncio da oficina de Francisco Pimenta

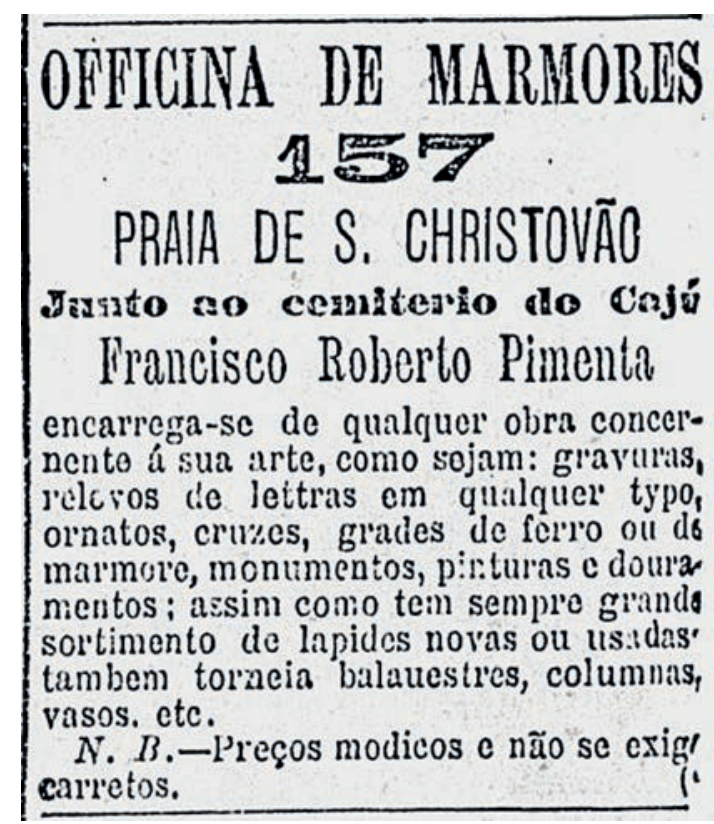

Fonte: Gazeta de Notícias, 08 set. 1881, Biblioteca Nacional.

Francisco era votante, sua renda segundo a lista de qualificação em 1877 era de $1 \$ 200$. No entanto, quando a Lei Saraiva foi instituída em 1881, precisou entrar com recurso eleitoral, por ter sido excluído da lista de votantes, mas a mesa de qualificação o indeferiu por falta de prova legal de renda. Talvez os artesãos tivessem dificuldade de comprovar renda que, juntamente com a exigência de alfabetização, podem ter complicado a manutenção do direito de votar conquistado anteriormente. A próxima nota encontrada sobre o assunto foi na República, quando foi mesário das eleições no Caju (Jornal do Brasil, 30 dez. 1896).

Sua participação na localidade ia de subscrição de lista para testemunhar a realização dos serviços de limpeza da Praia de São Cristóvão prestados pela Empresa Gary (que deu origem ao nome dos atuais profissionais de limpeza de rua), subscrição de lista em prol das asiladas da misericórdia (Gazeta de Notícias, 09 mar. 1890), passando pela diretoria do Club de Regatas Cajuense, como segundo procurador, e da comissão de sindicância do Sport-Club que, segundo 
o jornal $O$ Sportman, de 16 de julho de 1887, era uma sociedade com intuito de promover exposições e corridas de cavalos, com distribuição de prêmios. $\mathrm{O}$ noticiário do Gazeta de Notícias, de 29 de julho de 1888, informa que o Clube de Regatas do Caju estava se preparando para colaborar com a Câmara Municipal na organização dos festejos da chegada do Imperador, que incluía a participação de alunos das escolas públicas nas equipes que disputariam o páreo.

A imersão de Francisco em associações desportivas se destaca em razão de ser algo pouco comum entre os investigados. Mas, vários alunos atuaram na direção de sociedades e associações de diversas finalidades, sendo possível observá-los em quase todas as modalidades do esquema construído por Pereira de Jesus (2013) em que a tipologia de associações no século XIX se organizam em oito grupos: sociedades beneficentes; irmandades; sociedades religiosas; sociedades literárias e de instrução; sociedades científicas; sociedades dramáticas, recreativas e desportivas; caixas previdenciárias e montepios; e seguradoras e cooperativas.

Um deles se destaca por ter uma atuação associativista mais intensa. Manoel Nunes Pinheiro, matriculado em janeiro de 1855, aos nove anos de idade: "inteligência regular", "aplicação regular", "moralidade boa”. O grau de instrução na entrada: $7^{\text {a }}$ classe de leitura, $8^{\text {a }}$ de escrita e $6^{a}$ de contas. Em abril de 1855 , estava na $7^{\text {a }}$ de leitura, $9^{\text {a }}$ de escrita e $8^{\text {a }}$ de contas. Em três meses, o aluno passou da $8^{a}$ classe de escrita para a $9^{a}$, da $6^{a}$ classe de contas para a $8^{a}$ e permaneceu na mesma de leitura. Considerando que as classes do professor Pardal iam até a 10a , o aluno parecia bastante adiantado comparativamente com os outros da idade.

Seu pai, já mencionado neste capítulo, exercia no mesmo endereço fornecido como residência a atividade de sapateiro, que foi alterado, em 1857, para Rua da Saúde n. ${ }^{\circ} 231$, conforme a lista de "Fábrica de calçados e lojas de sapateiros" do Almanak Laemmert. O filho parece não ter adentrado no ramo dos sapatos, mas manteve-se no ofício de artista. Na lista de qualificação votantes de 1876 , Manoel foi apresentado como carpinteiro, que sabe ler, com renda de $1 \$ 000$, casado, elegível.

O carpinteiro, ex-aluno regular e "adiantado" da escola de Santa Rita, onde se deu uma parte de sua escolarização, teve significativa participação durante o período considerado por alguns pesquisadores como de emergência da organização operária. Sua inserção nos quadros administrativos dos movimentos associativistas chama atenção e saber ler, escrever e contar pode ter contribuído para que Manoel exercesse tais cargos da diretoria que igualmente consistiam 
em privilegiado espaço para aprendizagem de outras formas da cultura letrada (Costa, 2012).

Quadro 21 - Manoel Nunes Pinheiro e as associações
\begin{tabular}{|c|l|l|}
\hline N. & Cargos/Instituição & Fonte/Ordem cronológica \\
\hline 1 & $\begin{array}{l}\text { Tesoureiro interino da Associação de Socorros Mútuos Liga } \\
\text { Operária }\end{array}$ & Gazeta de Notícias, 16 jun. 1878 \\
\hline 2 & Tesoureiro da Associação de S.M. Liga Operária & Gazeta de Notícias, 14 jan. 1880 \\
\hline 3 & $\begin{array}{l}\text { Conselheiro da Sociedade Beneficente dos Marceneiros, } \\
\text { carpinteiros e artes correlativas }\end{array}$ & Gazeta de Notícias, 17 jan. 1882 \\
\hline 4 & $\begin{array}{l}2^{\circ} \text { Secretário da Associação de S.M. Liga Operária (na reunião } \\
\text { foi conferido a Manoel o diploma de sócio benemérito) }\end{array}$ & Gazeta de Notícias, 15 maio 1882 \\
\hline 5 & $\begin{array}{l}\text { Membro da comissão de sindicância da Sociedade de } \\
\text { Beneficência Perfeita Amizade }\end{array}$ & Gazeta de Notícias, 01 ago. 1882 \\
\hline 6 & $\begin{array}{l}\text { Membro do conselho da Associação de Socorros Mútuos } \\
\text { Memória à Restauração de Portugal }\end{array}$ & Gazeta de Notícias, 16 ago. 1882 \\
\hline 7 & Secretário da Associação Real de Socorros Mutuo D. Luiz I & AL, 1883, p. 1172 \\
\hline 8 & $\begin{array}{l}\text { Conselheiro membro fundador da Associação da Providência } \\
\text { Doméstica }\end{array}$ & A folha nova, 15 jul. 1883 \\
\hline
\end{tabular}

Fonte: Quadro elaborado pela autora com base nas informaçôes levantadas nos jornais da Hemeroteca Digital da Biblioteca Nacional e no Almanak Laemmert.

Ao todo foram sete cargos ocupados em seis associações de caráter beneficente ou de auxílio mútuo. Instituições que alcançaram, de acordo com Pereira de Jesus (2013), diversidade social e institucional expressivas na segunda metade do século XIX e que exerceram "um papel específico na segurança social, material e moral de artesãos, operários, ex-escravos, industriais, comerciantes, engenheiros, advogados e médicos, entre outros setores" (p. 1).

Entre as associações das quais participou Manoel encontra-se a conhecida Associação de Socorros Mútuos Liga Operária, fundada em 1870 (Batalha, 2009). A Liga Operária reuniu sócios de diversas categorias de operários e artistas, nacionais e estrangeiros. Alguns dias após a primeira sessão contava com 856 inscritos (Batalha, 2009). Os objetivos definidos no estatuto eram de prestar aos associados necessitados auxilio moral; "melhorar a sorte das classes operárias, introduzindo melhoramentos em todos os ramos do trabalho artístico e industrial"; e propagar a instrução, como meio de elucidar o operário e o artista "tanto na invenção, como na prática do trabalho manual". A diretoria era 
composta por uma quantidade de membros equivalente ao número de profissões representadas na Liga. Para Costa (2012, p. 130),

A experiência na direção de uma Sociedade poderia ter forte resultado educativo para um trabalhador, em função do próprio esforço para elaborar e comunicar o pensamento, os cálculos para tomada de decisões envolvendo variáveis complexas presentes nos assuntos de interesse coletivo, até a própria necessidade de lidar com as técnicas veiculadas pela escola, principalmente a leitura e escrita.

Tal experiência foi vivida por Manoel na Liga Operária, na condição de tesoureiro interino, tesoureiro e secretário, tendo repetido esses cargos mais de uma vez. Segundo o estatuto, os secretários tinham como deveres presidir as sessões na falta do presidente e do vice-presidente, organizar as atas das sessões e os livros das matrículas dos sócios, "dar desenvolvimento" ao expediente da secretaria e servir de bibliotecário. O tesoureiro deveria arrecadar o dinheiro da associação, cumprir as ordens da Diretoria Central referentes aos socorros pecuniários, organizar o balanço geral da associação, ter a seu cargo "os livros de receita e despesa e os auxiliares que julgar convenientes" e "cadernos de talóes com recibos impressos".

Pelo estatuto, nota-se que a função de tesoureiro exigia operar com diversos tipos de documentos, bem como o exercício da contabilidade. Atividade possível para Manoel por ter um domínio da leitura e escrita, cujos documentos produzidos também poderiam permitir aos outros sujeitos o acesso à cultura letrada. Leis, atas, livros de receita e despesa e de matrícula, talões e relatórios, ao fazerem parte da vida associativa, demonstram a "estreita ligação dos sujeitos aqui caracterizados com o mundo da escrita e da leitura. Mesmo os que possivelmente não soubessem ler e escrever presenciavam e escutavam a leitura de relatórios e balanços de gestão em assembleia" (Costa, p.127).

Manoel enquanto $2 .^{\circ}$ secretário também exerceu outra atividade, a de bibliotecário, que demonstra a preocupação da associação em favorecer o acesso de seus sócios ao mundo letrado. Preocupação assinalada no estatuto em "melhorar a sorte das classes operárias, introduzindo melhoramentos em todos os ramos do trabalho artístico e industrial" e que se traduziu, por exemplo, por meio de conferências e de cursos realizados em 1877 sobre temas diversos voltados para educação do operariado (Batalha, 2009).

Outro aspecto que pode ser observado é a rede de solidariedade estabelecida entre tais associações, que se dava, por exemplo, por meio da cessão do uso 
de espaço, como no caso da reunião de instalação da Associação de Socorros Mútuos Memória à Restauração de Portugal, da qual participou Manoel, que ocorreu na sala da Sociedade Auxiliadora dos Artistas Alfaiates. Tal aspecto pode favorecer a circulação dos sujeitos por diferentes associações, como o próprio caso de Manoel que esteve engajado em várias, ou mesmo favorecer a emergência de uma noção de coletividade mais ampla, ainda que envolvendo pessoas de diferentes instituições.

Outros ex-alunos também estiveram envolvidos com sociedades e associações de categorias profissionais, como o tipógrafo Luiz Antunes de Ferreira, membro da comissão artística e secretário da Imperial Associação Tipográfica Fluminense e presidente da Sociedade Beneficente dos Empregados da Gazeta de Notícias (Gazeta de Notícias, 20 jul. 1884); Theodoro Jansen Muller membro da Imperial Sociedade de Beneficência Protetora dos Guardas Nacionais da Corte e da Província do Rio de Janeiro (Correio Mercantil, 11 jul. 1868); e o professor Manoel Ribeiro de Oliveira Leão inscrito no Instituto Pedagógico ( $A$ Instruç̧ão Pública, 01 set. 1873).

Alguns tiveram inserção na direção de outros tipos de sociedades, como Theodoro Jansen Muller que foi membro da Sociedade Sete de Setembro, secretário do Congresso Juvenil (criado para promover o desenvolvimento das artes), vice-presidente do Congresso Juvenil Artístico e secretário da Sociedade Festival de São Pedro do Saco do Alferes; o artista Alexandre Aristides Pinheiro, conselheiro da Sociedade União Funerária Primeiro de Julho; o músico Henrique Gomes Braga que fazia apresentações musicais no Club Mozart; José Antonio Ferreira Leal, sócio efetivo da Sociedade Auxiliadora da Indústria Nacional; o guarda da Alfândega João Luis da Costa Oliveira Junior, secretário da Sociedade Teatral Obreiros do Porvir; o negociante Henrique de Oliveira Lemos, mesário da Irmandade do Santíssimo Sacramento; e o médico e farmacêutico Francisco Ferraz de Macedo, sócio fundador do Liceu Literário Português e diretor geral do Montepio Agrícola. A diversidade mostra que tais sujeitos tiveram inserção em diferentes campos, envolvendo instituições beneficentes nas quais se buscava alguma segurança e auxílio, mas também aquelas de caráter recreativo, voltadas para o lazer e ligadas à arte, como a música, a literatura e o teatro.

A variedade de instituições associativas também remete à variedade de ocupações seguidas pelos ex-alunos, sendo que alguns casos chamam atenção por destoarem do restante do conjunto identificado na pesquisa, como o do noviço, 
do artista de teatro, do farmacêutico/ médico que se tornou antropologista criminal e o do músico já mencionado.

Francisco José Ferreira Villaça, cujo pai caixeiro despachante de mesmo nome faleceu em 1855, entrou como noviço na ordem beneditina e viajou para Roma com o frei João de Santa Gertrudes, custeados pelo mosteiro. No entanto, havia uma complicação de ordem legal. O Ministro do Império declarou que, por causa da circular de 19 de maio de 1855, que cassou as licenças para admissão de noviços nas ordens religiosas do Brasil, aqueles que haviam viajado com o frei de Santa Gertrudes não poderiam voltar ao Brasil como parte da ordem beneditina (O Apóstolo, 06 nov. 1870). Ou seja, se Francisco quisesse ser monge não poderia voltar ao Brasil. O comunicado causou polêmica na Igreja e o jornal católico $O$ Apóstolo, em 12 de fevereiro de 1871, transcreveu artigo publicado no jornal Catholico de Pernambuco, criticando o que chamou de "violação da liberdade católica" e acusando o governo de querer extinguir as ordens brasileiras "como meio iniquo de chegar à posse dos bens dessas mesmas ordens, como afinal chegou-se de um modo indireto". Coincidentemente, após essa data não foi possível encontrar mais nenhuma nota de Francisco José Ferreira Villaça nos jornais.

O ex-aluno Peregrino Lemos de Menezes tornou-se tanto artista tipógrafo quanto artista de teatro. Possui um verbete no livro "Carteira do artista", publicado 1898 por Souza Bastos, o qual afirma que Peregrino "filho de pais pobres apenas recebeu rudimentos de instrução primária”. Na data de matrícula seu grau de entrada, foi classificado $5^{\text {a }}$ classe de leitura, $6^{a}$ de escrita e $4^{a}$ de contas. $\mathrm{Na}$ avaliação inicial, foi considerado pelo professor com "muita inteligência", "regular aplicação" e "boa moralidade". No mapa de 1856, constava que ele estava na $10^{\text {a }}$ classe de leitura, $8^{\text {a }}$ de escrita e de contas. Mas foi avaliado como tendo "pouca inteligência", "regular aplicação e moralidade". O verbete diz que, impossibilitado de seguir a carreira da Marinha, foi aprender a arte tipográfica. Depois foi empregado na capatazia da Alfândega e em seguida tornou-se empregado da Tipografia Nacional.

A inserção na carreira de ator se deu na companhia de teatro de Manuel Di-Giovani. Em 1874, Peregrino casou-se com a viúva do diretor, Jesuína Montani Di-Giovani. Existem algumas divergências a respeito de datas e informações sobre a vida do artista que aparecem em alguns jornais, mas ele ainda é citado no jornal A Manhã de 12 de agosto de 1945, numa reportagem intitulada "O ator Peregrino - considerado antigamente - Pau para toda obra” que elogiava a habilidade, em 
falta naquele momento, do ator em interpretar diferentes papéis, o que lhe rendeu um repertório eclético de atuações.

Peregrino morreu moço, como declararam os jornais, aos 42 anos. A Gazeta da Tarde ao tratar da morte do ator encerra a notícia com tom dramático característico do ramo: "Como quase todos os atores depois de ter acordado sua alma ao estrepitar das palmas, o distinto brasileiro, ferido da morte, tropeçou no túmulo, deixando apenas à família que a tinha e numerosa, como triste legado a perspectiva da pobreza” (21 jan. 1885). A perspectiva parecia ser um problema comum no ofício. Os atores tinham suas redes de solidariedade, que também foram acionadas no caso da morte de Peregrino. No Teatro São Luiz ocorreu uma apresentação da peça "A cabana do Pai Thomaz" em benefício da viúva e dos filhos do ator (Brazil, 08 fev. 1885).

O caso do português Francisco Ferraz de Macedo, nascido no Porto, conforme registra o mapa de matrícula também se sobressai. Francisco foi aprovado nos exames para matrícula nos cursos superiores em 1864 (Correio Mercantil, 08 jan. 1864). Consta que ele cursou filosofia racional e moral no Colégio do Mosteiro de São Bento (Correio Mercantil, 14 jan. 1865). Fez o curso de farmácia (concluído em 1867) e de medicina (em 1873) na Faculdade de Medicina da Corte e, em 1879, já estava atestando a eficiência de xarope em propaganda de jornal (Gazeta de Notícias, 04 fev. 1879). Indício de que a técnica publicitária de usar o nome de profissionais e de pessoas de reconhecimento para dar credibilidade a um produto constitui prática antiga.

Francisco foi sócio-fundador do Liceu Literário Português, uma demonstração de sua forte relação com seu país de origem e que ajuda a entender a sua mudança, na década de 1890, para Portugal, onde investiu na carreira de antropologia criminal e arqueologia. No entanto, continuou mantendo contato com seus colegas brasileiros, como se pode observar pela nota em que oferece livros à Sociedade de Jurisprudência Médica e Antropologia (O Paiz, 02 fev. 1898). Jornais do Brasil noticiam sua atuação no exterior, como a de que o "um dos mais distintos antropologistas europeus" iria representar Portugal no Congresso de Antropologia Criminal em Genebra (Jornal do Brasil, 25 jun. 1896). Outro jornal ao dar a mesma notícia faz um pequeno resumo da vida de Francisco destacando que era membro da Sociedade de Antropologia de Paris e da equivalente em Florença (Gazeta da Tarde, 29 jun. 1896).

Também havia entre os alunos de 1855 aqueles que iriam seguir a carreira do professor Pardal. A docência se apresentava como um dos ofícios possíveis 
pela proximidade e pelo cargo do professor adjunto. Matheus de Oliveira Borges, embora o pai fosse negociante, proprietário de bens e de escravos, tornou-se adjunto na própria freguesia de Santa Rita e exerceu a função de 1859 até 1862, quando foi exonerado. Apesar da iniciativa, a imersão na carreira docente parece não ter sido promissora, pois anos depois vemos o nome de Matheus nas folhas do Almanak Laemmert na sessão de negociantes de materiais para obra, mesmo negócio do seu falecido pai, com endereços na Rua da Saúde e no Largo da Imperatriz, logradouros próximos à escola.

Manoel Ribeiro de Oliveira Leão, quinze anos, matrícula de junho de 1854, "inteligência pouca”, "aplicação pouca”, “moralidade boa”. Grau de instrução na entrada: $8^{a}$ classe de leitura, $10^{a}$ de escrita e $10^{a}$ de contas. Grau de instrução em abril de 1855: 9a de leitura e de escrita e 10a de contas. Em 1862, aos 22 anos de idade, fez exame de habilitação e "aprovado pela inspetoria geral da instrução publica” passou a oferecer seu préstimo, dando início a sua inserção no "comércio da instrução" (Limeira, 2010). Uma propaganda no jornal Correio Mercantil de 08 de junho de 1862 anunciava seu endereço e horário para os interessados. A informação do horário se destaca: a partir das seis horas da tarde.

Figura 25 - Propaganda de aula particular de Manoel Leão em 1862

\section{InSTRICGÃo PRINARIA.}

0 abaixo assignado, cxaminado nas materias da instrucção primaria, e approvado pela inspectoria geral dá instrucção publica, ofierece o seu prestimo para leccionar por collegios ou casas particulares. Tambem dá liçóes em sua propria casa (á praia de $\mathrm{S}$. Clıristovão n. 5) das 6 horag da tarde em diante. As pessoas que quizerem utilisar-se de seu prestimo podem dirigir-se por carta ao Correio Mlercantil, ' ou á rua do Sabão n. 114. - Manoel Ribeiro de

Fonte: Correio Mercantil, 08 jun. 1862, Biblioteca Nacional. 
Como talvez a procura pelo serviço não tivesse sido satisfatória para Manoel, no anúncio do ano seguinte, o professor apresentou uma "promoção": o valor da aula, $3 \$$ mensais, para quem matricular-se "desde já”. O valor muito baixo da mensalidade pode ajudar a pensar a razão das aulas ocorrerem a partir das seis horas da tarde. Talvez fosse um complemento de renda, tendo o professor outro emprego durante o dia. Mas a docência noturna na Corte dará lugar ao magistério público em outras cidades. Em 1870, Manoel foi nomeado professor no município de Campos e, a partir de então, começou um ciclo de remoções, cuja última notícia é de 1886. Primeiramente, no interior do próprio município de Campos (1870-1875), depois para Nova Friburgo (1875), Vila da Estrela (1877), Petrópolis (1879) e Guapimirim (1886). Nesse tempo o professor foi convocado duas vezes para fazer exame de sanidade, em 1877 e em 1885.

Figura 26 - Propaganda de aula particular de Manoel Leão em 1863

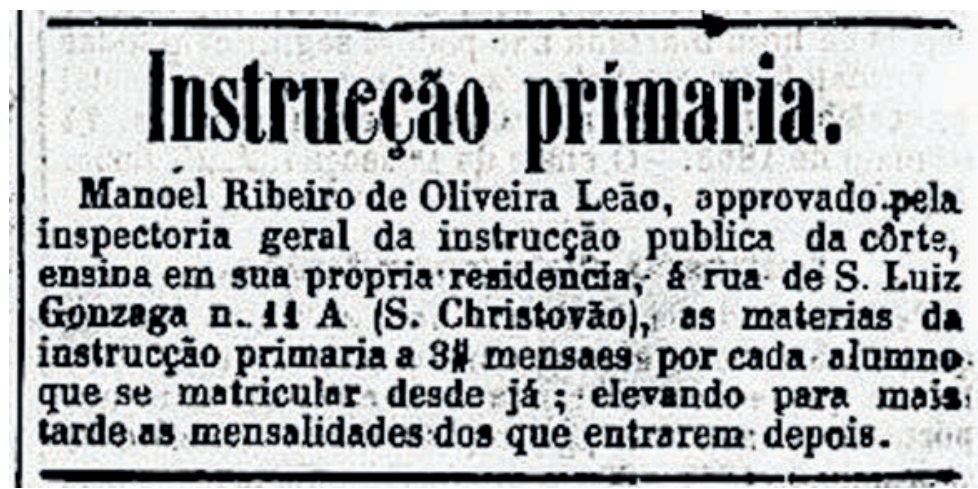

Fonte: Correio Mercantil, 25/05/1863, Biblioteca Nacional.

Membro do Instituto Pedagógico e com certo envolvimento cultural sua casa constava nos jornais como ponto de venda do livro Voz da Amizade -, o aluno "pouco inteligente e aplicado", com suspeita de insanidade recebeu um agradecimento público pelos donativos às vítimas da seca do Norte, em 1878 ( $O$ Cruzeiro, 24 fev. 1878). Pelo noticiário não foi possível saber a razão do exame de sanidade, mas sua submissão ao procedimento, embora o médico o tivesse considerado apto a exercer o ofício, não deve ser ignorada, podendo indicar a existência de tensões com determinados sujeitos ou a realização de práticas consideradas, naquele momento, inadequadas para um professor. 
João Luis da Costa Oliveira Junior, já mencionado como guarda da Alfândega e praticante da Recebedoria do Rio de Janeiro, também se inseriu na docência muitos anos depois. Recebeu diploma de professor de aritmética pelo Liceu de Artes e Ofícios, em 1889, numa lista que inclui várias pessoas de idade mais avançada, e tornou-se professor do próprio Liceu (Diário do Comércio, 21 dez. 1889).

João Miguel Salgueiro foi o único da lista de 1855 identificado como aluno do Externato do Colégio Pedro II, em 1861, aprovado plenamente em geografia, doutrina cristã e aritmética e simplesmente nas demais (Correio Mercantil, 16 nov. 1861). Salgueiro seguiu o ofício docente. Em 1871, constava numa lista de professores de português do Relatório da Inspetoria (11 abr. 1872) e foi um pouco mais longe, no sentido geográfico, que o professor Manoel Ribeiro de Oliveira Leão. Em vez de circular apenas pela província, João Miguel lecionou em Petrópolis, Juiz de Fora e São Paulo. Em 1887 aparece na lista de professores da Escola Normal da Corte que estava funcionando no Externato Andrade, localizado na Rua do Sacramento (Gazeta de Notícias, 18 maio 1887).

Os ex-alunos Manoel, João Luís e João Miguel tiveram experiências bastante diferenciadas na docência: professor de primeiras letras, de aritmética e da escola normal que envolveu a circulação geográfica e profissional, ao contrário de Pardal que sempre atuou como professor e que, durante quase toda sua vida profissional, lecionou na freguesia de Santa Rita, mesmo trabalhando em mais de uma instituição.

Por outro lado, a fixação geográfica de Pardal permitiu que ele pudesse construir relações mais duradouras, o que não significa que fossem necessariamente amistosas. Os caminhos de ex-alunos, pais, encarregados e o professor se cruzaram várias vezes após a saída dos meninos da escola (prematura ou mediante conclusão dos estudos), pois, como personagens dinâmicas, frequentavam e atuavam em outros espaços. Esses espaços, embora não fossem mais a escola, também eram lugares de aprendizagem, como assinala Costa (2012) que, operando com uma concepção mais ampla de educação, faz uma análise sobre "educar-se como a experiência vivida, o ensinar e o aprender entre os próprios sujeitos populares, mesmo fora da escola, fosse em associações de trabalhadores, ou de forma mais difusa no seu cotidiano" (p. 20).

O encontro com pais e encarregados em momento em que seus filhos não mais frequentavam a escola de Santa Rita foi assinalado no item anterior. Quanto aos ex-alunos, podemos citar espaços como o Colégio Pedro II, a Sociedade Auxiliadora da Indústria Nacional, o Club Mozart e também as eleições e o júri 
da Corte. Isso para mencionar os espaços que puderam ser identificados pelos jornais, mas que, muito provavelmente, poderiam englobar uma série de outras instituições, diante do movimento da vida que tais sujeitos levavam.

Saber ler, escrever e contar certamente fez diferença nas maneiras como os indivíduos se posicionavam perante os outros e as instituições com as quais deveriam lidar no cotidiano, bem como no exercício de suas atividades profissionais, políticas, religiosas, sociais e culturais. Embora nem todos tivessem iniciado a escolarização na Escola Pública de Santa Rita, a aprendizagem das primeiras letras nessa escola fez parte da trajetória de artesãos, artistas, negociantes, empregados públicos, militares, professores, entre outros.

Nesse sentido, o exercício da leitura e da escrita em suas vidas cotidianas passa pela experiência de aprender com o professor Pardal e suas agências, com o qual os alunos também podem ter aprendido mais do que os conteúdos escolares. Ao vivenciarem um espaço em que seus pais, encarregados e o professor, no exercício de outras atividades, travavam relações fora do ambiente escolar, mas estavam, ao mesmo tempo, em conexão com ele. Poderiam aprender jogos políticos, estratégias de resistências, de reinvindicação, formas de inserção na cidade, modos de ser e estar na Capital do Império, muitos dos quais registrados nas várias notas de jornais do século XIX. 